Portland State University

PDXScholar

1986

\title{
The geology and hydrothermal alteration of the Bear Creek Butte area, Crook County, central Oregon
}

Richard Matthew Wilkening

Portland State University

Follow this and additional works at: https://pdxscholar.library.pdx.edu/open_access_etds

Part of the Geology Commons, Hydrology Commons, and the Mineral Physics Commons Let us know how access to this document benefits you.

\section{Recommended Citation}

Wilkening, Richard Matthew, "The geology and hydrothermal alteration of the Bear Creek Butte area, Crook County, central Oregon" (1986). Dissertations and Theses. Paper 3656.

https://doi.org/10.15760/etd.5542

This Thesis is brought to you for free and open access. It has been accepted for inclusion in Dissertations and Theses by an authorized administrator of PDXScholar. Please contact us if we can make this document more accessible: pdxscholar@pdx.edu. 
AN ABSTRACT OF THE THESIS OF Richard Matthew Wilkening for the Masters of Science in Geology presented April, 24, 1986.

Title: The Geology and Hydrothermal Alteration of the Bear Creek Butte area, Crook County, Central Oregon:

APPROVED BY THE MEMBERS OF THE THESIS COMMITTEE:

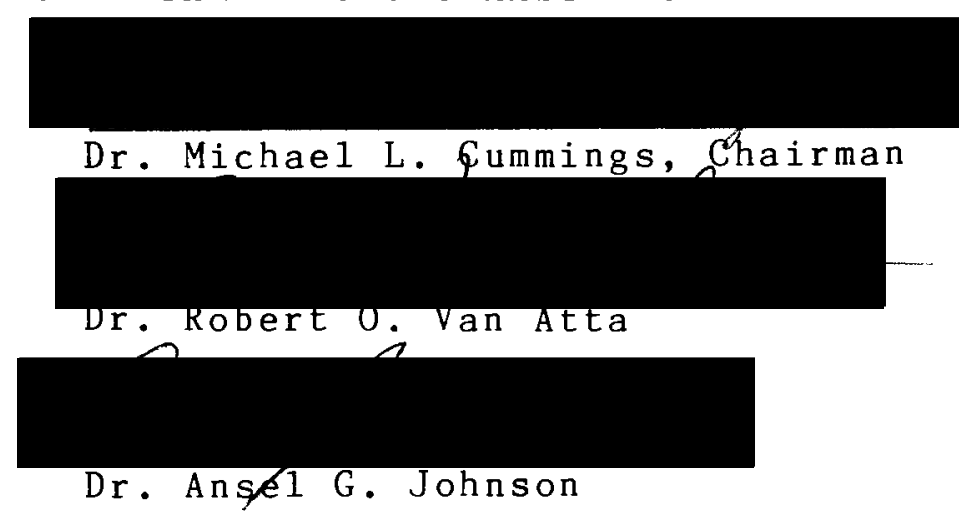

The Eocene Clarno Formation, the Oligocene John Day Formation and basalts of the High Lava Plains are exposed in the Bear Creek Butte area in Central Oregon. In this area the Clarno Formation can be divided into a lower sequence composed of intermediate lava flows with intercalated mudflows and volcaniclastic sediments and an upper sequence of rhyolite and basalt flows and felsic tuffs. Separating the two units is a well developed 
saprolite. The change from intermediate to rhyolite-basalt volcanism reflects a change in the tectonic environment of the Cascade volcanic arc from compression to relaxation as subduction of the Farallon plate by the North American plate slowed, allowing extension of the continental plate margin to occur.

Hydrothermal alteration has affected rocks of the Clarno and John Day Formations in the Bear Creek Butte area. The Oronogo and Platner mines, and the Admunsen prospect, currently being worked, are hosted in the Clarno Formation. Alteration is most intense at the Platner mine where hydrothermal alteration forms an e11ipse a1ong $N-N W-$ trending faults. Hydrothermal breccias are associated with silicified and kaolinitized felsic tuffs and a mafic intrusion at this mine. At the Admunsen claim, located south of the Platner mine, a mafic intrusion is argillized and cut by fine quartz veinlets and felsic tuffs have been silicified. At the Oronogo mine, the northernmost property, alteration zones are confined to fractured basaltic andesite along a NW-trending fault. Alteration consists of silicification with minor argillization of plagioclase phenocrysts in the basaltic andesite.

The Platner mine contains the highest concentrations of As and $\mathrm{Sb}$. Trace element geochemistry indicates Sb concentrations (maximum 102 ppm, average 44 ppm) are highest in the area of the Platner mine and decrease 
northward along the controlling structure more gradually than to the south of the mine. Arsenic concentrations increase northward along the controlling structure from the Platner mine (maximum $45 \mathrm{ppm}$, average $12 \mathrm{ppm}$ ). $\mathrm{Hg}$ is irregularly distributed along the structure and has its highest concentration south of the Platner mine. Trace concentrations of U occur along the fault zones in the areas of alteration.

Altered rocks of the John Day Formation, which unconformably overlies the Clarno Formation, host uranium mineralization. The alteration zones are located along NWWNW-trending faults. The alteration assemblages are similar to that at the mercury prospects; clays, predominately kaolinite, and fine grained quartz. Trace element geochemistry indicates anomalous U (maximum 59 ppm, average $24 \mathrm{ppm}$ ) and Mo concentrations.

The presence of cinnabar + hematite + pyrite indicates that the hydrothermal system that operated at the mercury prospects was an oxidizing system. Deposition of $U$ and Mo required a reducing enviroment. The differences in the environment of deposition for mercury and uranium indicate that two different systems were active in the study area. Although alteration is extensive and hydrothermal breccias are present in the Bear Creek area, significant base and precious metal anomalies have not been detected along controlling structures. 
THE GEOLOGY AND HYDROTHERMAL ALTERATION

OF THE

BEAR CREEK BUTTE AREA, CROOK COUNTY, CENTRAL OREGON

by

RICHARD MATTHEW WILKENING

A thesis submitted in partial fulfillment of the requirements of the degree of

\section{MASTER OF SCIENCE \\ in \\ GEOLOGY}

Portland State University

1986 
TO THE OFFICE OF GRADUATE STUDIES AND REASEARCH:

The members of the Committee approve the thesis of

Richard Matthew Wilkening presented April 24, 1986.

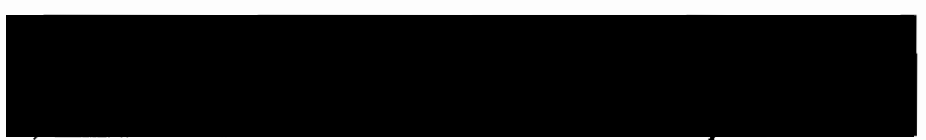

Michagl L. Cumprings, Chaizhan

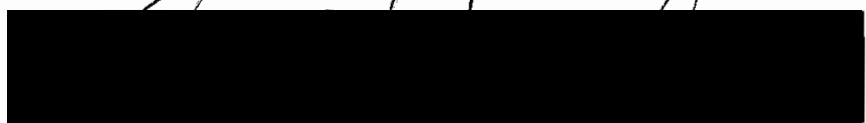

Anse1 G. Johnson

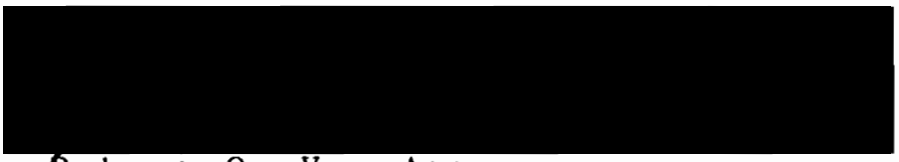

Robert 0. Van Atta

APPROVED :
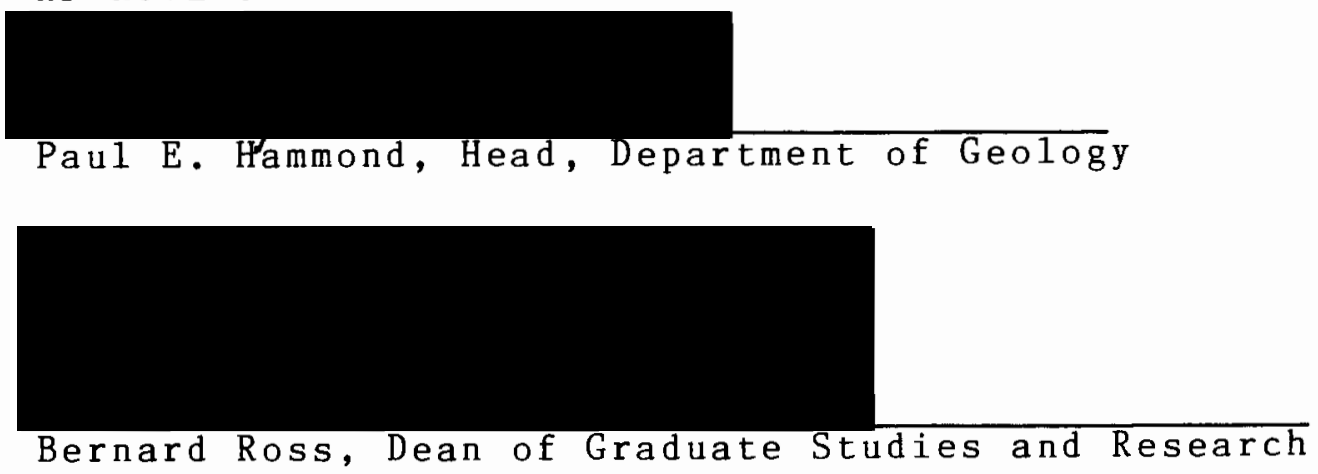


\section{ACKNOWLEDGEMENTS}

This work was funded by a grant from the minerals division of Phillips Petroleum Company. Also this study would not have been possible without access to the property of Richard Kleinheinz.

I also wish to thank my advisor, Dr. Michael Cummings, for providing helpful assistance with this study and the carrots and occasional sticks in order to speed completion of this work. Doctors A. G. Johnson and R. O. Van Atta critically read the thesis and provided helpful suggestions. Jerry Gray of DOGAMI provided valuable technical information. I also thank Dorinda Himes for providing some of the trace element data and Larry Stanford for providing personal contacts with the ranchers in the study area. 
TABLE OF CONTENTS

PAGE

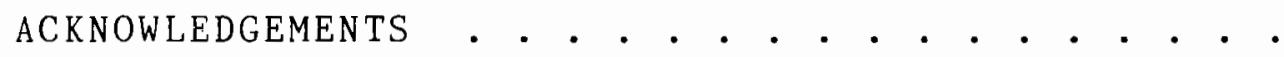

LIST OF TABLES . . . . . . . . . . . . . . . vii

LIST OF FIGURES . . . . . . . . . . . . . . . viii

Plates ................. . . . Back

CHAPTER

I INTRODUCTION . . . . . . . . . . . . . . 1

Location . . . . . . . . . . 3

Purpose and Scope........... . . 3

Previous Work. . . . . . . . . . 6

II STRATIGRAPHY . . . . . . . . . . . . 10

Clarno Formation . . . . . . . . 10

John Day Formation . . . . . . . 20

Basalts of the High Lava Plains... . 22

Alteration mineralogy . . . . . . . 23

Strong hydrothermal alteration zone Moderate hydrothermal alteration zone Weak hydrothermal a1teration zone

Uranium prospects . . . . . . . . .

Fumerolic alteration . . . . . . . 
III GEOCHEMISTRY • • • • • • • • • • • • •

Geochemistry of the Clarno Formation.

Geochemistry of basalt of the High Lava Plains

Geochemistry of the cinnabar prospects

Geochemistry of the uranium prospects.

Geochemistry of fumerolic alteration. .

Stratigraphy . . . . . . . . . . .

The Clarno Formation and the regional tectonic setting . . . . . . . . . .

Epithermal systems and hydrotherma1 alteration . . . . . . . . . . . . .

Deposition of silica . . . . . . . . .

Deposition of mercury . . . . . . . .

Deposition of other elements . . . . . .

Argillic alteration . . . . . . . . .

Sinter deposits and the paleosurface.

Model of the hydrothermal system at the cinnabar prospects . . . . . . . .

Hydrothermal alteration at the uranium prospects . . . . . . . . . . . 95

Deposition of molybdenum . . . . . . . . 97

Model of the formation of the uranium prospects . . . . . . . . . . . 9 98

Age of mineralization . . . . . . . 101

Fumerolic alteration . . . . . . . 102 
CHAPTER

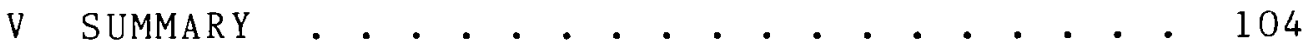
Conclusions............ 106 REFERENCES CITED . . . . . . . . . . . . . 108 APPENDICES . . . . . . . . . . . . . . . 120 


\section{LIST OF TABLES}

TABLE

PAGE

I Major oxide geochemistry . • • • • • • • • • 39

I Rare earth element ratios . . . . . . . . . 51

II Trace elements, As, $\mathrm{Sb}, \mathrm{Hg}$, and $\mathrm{U}$ for traverse at the Platner and Oronogo mines and the Admunsen claim . . . . . . . . . . . . 62

IV Trace elements, U, Sb, As, and Mo for the uranium prospects . . . . . . . . . . . . . . . 68

$\mathrm{V}$ Department of Geology and Mineral Industries Data 68 


\section{LIST OF FIGURES}

FIGURE

PAGE

1. Location map. . . . . . . . . . . . . 4

2. Stratigraphy. . . . . . . . . . . . 11-12

3. Photomicrograph of augite-bearing basaltic andesite . . . . . . . . . . . . . . 20

4. Alteration of mercury prospects . . . . . 25-26

5. Map of the Platner mine . . . . . . . . 27

6. Map of the Admunsen claim . . . . . . . . 28

7. Map of the Oronogomine . . . . . . . . . 29

8. Photomicrograph of altered mafic intrusion . 31

9. AFM diagram . . . . . . . . . . . . 40

10. Total alkaline plot . . . . . . . . . . 40

11. Harker variation diagrams of major oxides . 41-43

12. REE graph of unaltered rocks . . . . . . . 52

13. REE graphs of Platner mine traverses . . . 56-57

14. Hf vs Ta graph . . . . . . . . . . . . . 58

15. REE graphs of samples from the Admunsen claim and the Oronogo mine . . . . . . . . . . . . 59

16. REE graphs of samples from the uranium prospects and fumerolic alteration . . . . . . . . 65 


\section{CHAPTER I}

\section{INTRODUCTION}

The association of mercury and gold in epithermal precious metal deposits has resulted in the reevaluation of many of the mercury properties within the Western United States. An example of this association is the McLaughlin mine, one of the largest gold mines in the U. S., which is located on the site of the Manhattan mercury mine in Northern California (Burnett, 1986). This thesis is an outgrowth of such interest in which the potential for precious metal mineralization at the abandoned mercury mines in the Bear Creek Butte area was investigated.

Volcanic hosted epithermal precious metal deposits are characterized by similarities in alteration assemblages, trace element concentrations, structural features and a similar range of temperature and depth of formation. Surface features associated with these deposits include zones of commonly recemented hydrothermal breccia, intensive silicification and propyllitization of wall rocks, and the presence of mercury as cinnabar. These surficial characteristics are present in the rocks of the Clarno Formation at Bear Creek Butte, Crook County, Oregon, 
suggesting possible precious metal mineralization in the area, possibly at depth. Models of volcanic hosted epithermal precious metal deposits have been developed by Ewers and Keyes (1977), Buchanan (1981) Fournier (1983), and Berger and Eimon (1983), and the characteristics of sediment- and volcanic-hosted deposits are reviewed in Tooker (1985). Structura1, geochemical, and stratigraphic studies of the abandoned mercury prospects at the Platner and Oronogo mines and areas surrounding Bear Creek Butte indicate similarities to these models.

Geochemical studies by Novitsky-Evans (1974), Rogers and Novitsky-Evans (1977a, 1977b), Rogers and Ragland (1980) and Rogers and others (1974) demonstrate a strong similarity between the calc-alkalic rocks of the Eocence age Clarno Formation and those of a volcanic arc complex. Sawkins (1984) indicates that vein deposits are widespread in such volcanic terranes. Studies by Silberman and others (1976) and Silberman (1983) indicate that many epithermal precious metal deposits occur within Cenozoic volcanic rocks of the Western U.S. Thus the age, tectonic setting and manner of hydrothermal alteration in the Bear Creek Butte area are similar to those at known epithermal precious metal deposits in volcanic terranes.

The Bear Creek Butte area is located along the northern boundary of the High Lava Plains physiographic province. The High Lava Plains are underlain by numerous 
Miocene-Pliocene basaltic lava flows (Walker, 1969). The Brothers fault zone, a series of en echelon normal faults associated with right-lateral strike-slip movement at depth, cut the lavas (Lawrence, 1976). In the Bear Creek Butte area erosion has cut through the onlapping high plains basalts exposing the underlying John Day Formation and the upper and lower Clarno Formation. Some faults in the study area have a similar trend to those of the Brothers fault zone.

\section{LOCATION}

The Bear Creek Butte study area is 1 ocated $50 \mathrm{~km}$. south of Prineville, Oregon in Crook County along Oregon State Highway 27 (Fig. 1). Fifty square kilometers were mapped. This area occurs on four U.S. Geologic Survey quadrangles; Powell Butte and Eagle Rock (both 15') and West Butte and Brothers NW (7.5').

\section{PURPOSE AND SCOPE}

The abandoned cinnabar prospects in the Bear Creek Butte area were investigated to determine the potential for precious metal mineralization in these areas in light of the models of epithermal gold deposits. In association with this study was an investigation of cinnabar prospects at Glass Buttes by Johnson (1984). It was hoped that the alteration at Bear Creek Butte was associated with the 

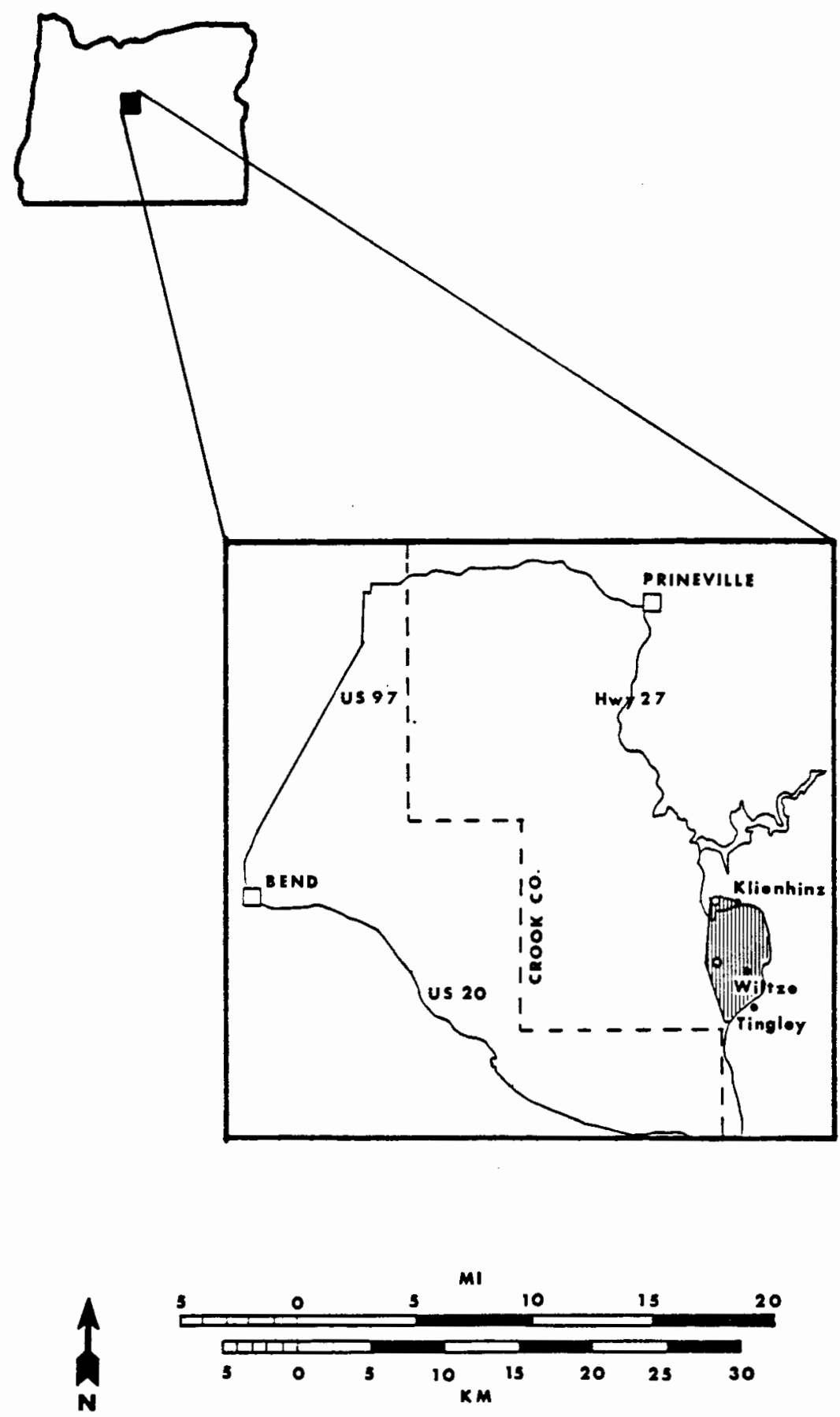

Figure 1. Location map 
emplacement of the rhyolite domes of the Eocence age Clarno Formation and that due to erosion, the alteration that is exposed in the study area would be deeper in an epithermal system than that exposed at Glass Buttes. Also this study was designed to provide information concerning the hydrothermal systems that operated in the Clarno Formation and the environment of deposition of the prospects.

The geology of the Bear Creek Butte area was mapped and the relationships among several abandoned mercury prospects and the surrounding rocks were investigated. This mapping provided information concerning stratigraphic and structural relationships among the rock units, faults, and hydrothermal alteration. The mapping and sample collection was completed during the summers of 1982 and 1983. The samples were examined petrographically and the alteration mineralogy was studied by $x$-ray diffraction. Major element chemistry was determined by $x$-ray fluoresence by Dr. Peter Hooper at Washington State University. Minor and trace element chemistry was obtained by instrumental neutron activation analysis (INAA). These samples were irradiated using the Triga Mark I reactor at Reed College, Portland, Oregon. The samples were counted and analyzed by the author at Portland State University. Combining these analyses with information from mapping, the nature and history of the hydrothermal alteration associated with the mercury and uranium prospects and the fumerolic alteration 
of the rhyolite domes was determined.

\section{PREVIOUS WORK}

Numerous geologic studies and maps have been published dealing with the lithologies and tectonic setting of the Clarno and John Day Formations. Some of the earliest studies in central Oregon include those by Merriam (1901) who described the geology of the John Day River Basin. He was the first to describe the Clarno Formation naming it after the nearby Clarno ferry on the John Day River. Dr. Thomas Condon, a pioneer geologist and missionary, collected fossils from the rocks in central oregon in the late 1800's (Condon, 1902). Swanson (1969) published a geologic map of the eastern half of the Bend $1^{\circ} \mathrm{X} 2^{\circ}$ sheet $(1: 250,000)$ which is a composite of his reconnaissance and previous work. The Crescent $1^{\circ} \mathrm{X} 2^{\circ}$ sheet $(1: 250,000)$ has been mapped on a reconnaissance basis by McLeod (in press). Oles and Enlows (1971) argued that the Clarno Formation be elevated from formation to group status on the basis of work in the Mitchell quadrangle. This change in status is based on the fact that two dissimilar sequences of rocks, each ascribed to the Clarno Formation in the Mitchell quadrangle, are separated by an angular unconformity. Several observations by Oles and Enlows (1971) support this division of the Clarno. In the Mitchell area erosion had cut deeply into the older rocks 
of the Clarno Formation. Numerous lava flows assigned to the Upper Clarno have filled these old erosional valleys as intracanyon flows and lap against the old paleotopography. Also rocks of the younger subgroup have not participated in orogenic episodes that deformed the underlying Cretaceous age rocks and rocks of the Lower Clarno in the Mitchell area. However, since the Group status of the Clarno Formation has not been formally established, Clarno Formation will be used in this study.

Numerous unpublished theses at Oregon State University and other universities have been completed in which the stratigraphy, petrology and/or geochemistry of the Clarno Formation and/or the John Day Formation are discussed (Novitsky-Evans, 1974; Huggins, 1977; Owen, 1977; Weidenheim, 1980).

The only previous detailed mapping in the Bear Creek Butte area was completed by Lowry (1940) for his master's thesis. Brookes (1963) briefly described the geology of the Platner and Oronogo mines in the Department of Geology and Minerals Industries Report 55, Quicksilver Deposits of Oregon.

There have been no age determinations from rocks in the study area. However, numerous age dates are available from rocks of the Clarno and John Day Formations and basalts of the High Plains. The dates have been compiled by Fiebelkorn and others (1983) and correlated to the 
Cenozoic geochronology compiled by Berggren and others (1985). Radiometric dates for the Clarno Formation span the time from 53.7 to 29.3 my., however, the generally accepted time span for the Clarno Formation is 43.1 to 34.0 my (Ba1dwin, 1976) spanning the Middle Eocene to Early Oligocene. The John Day Formation was deposited during the Late Oligocene to the Middle Miocene, 30.0 to 11.2 m.a. An age determination for a basalt flow near Millican in the High Lava Plains physiographic province indicates a Late Miocene age of $6.7 \mathrm{~m} . \mathrm{y}$.

The geologic setting of north central Oregon progressively changed from an initial Paleozoic marine environment to one characterized by continental fluvial sedimentation and subaerial volcanism (Wilkenson and Oles, 1968). Although the base of the Clarno Formation is not exposed in the Bear Creek Butte area, studies to the north in the Prineville-Mitchel1 area (Oles and Enlows, 1971) indicate that the Clarno Formation rests unconformably upon the Cretaceous marine sandstones of the Hudspeth Formation and the Gables Creek sandstones and conglomerates. There is a complex intertonguing relationship between these two formations which was interpreted by 0les and Enlows (1971) to represent deposition associated with a series of advancing and retreating shorelines during this period of time. However, Kleinhans and others (1984) have reinterpreted the Gable Creek Formation to have been 
deposited within a submarine turbidite system rather than being fluvial-deltaic in origin.

Geochemical studies by Novitsky-Evans (1974), Rogers and Novitsky-Evans (1977a, 1977b) and Rogers and Ragland (1980) indicated that the Clarno Formation was formed on a thin continental margin that was $20-30 \mathrm{~km}$ in thickness.

The John Day Formation was named by Marsh (1875) after the John Day River. Stratigraphic and petrographic studies by Merriam (1901), Calkins (1902), Coleman (1949), Waters (1954), Peck (1961, 1964), Fisher and Wilcox (1960), Hay (1962, 1963), and 01es and Enlows (1971) indicate that the John Day Formation consists largely of felsic pyroclastic debris of air-fall origin. The John Day is rich in fossils, particularly vertebrate remains (Knowlton, 1902) including oredonts, camels and a type of rhinoceros. Studies by Scott (1954) on fossil fruit and seed beds in the John Day provide excellent information on the flora during 0ligocene time. In the Bear Creek Butte area no vertebrate fossils have been discovered, however leaf fossils have been collected and described by Chany (1927) and Mote (1940). 


\section{CHAPTER II}

\section{STRAT IGRAPHY}

\section{Clarno Formation}

In the study area the rocks of the Clarno Formation are divided into two sequences based on 1 ithology as related to stratigraphic postion. These sequences are separated by a well developed reddish brown clayey soil zone. The lower group is composed of basaltic andesite lava flows, intercalated mudflows and volcaniclastic sediments. An erosional unconformity separates these rocks from the upper group which is composed of rhyolite flows, felsic tuffs and basaltic lavas. Another erosional unconformity separates these units from a tuffaceous siltstone and mudstone sequence of the John Day Formation exposed in the southwest area of the study area (P1ate 1). The plateau to the east and south are capped by younger basalt flows.

The lowermost exposed remnant of the lower sequence of the Clarno Formation in the study area is a series of basaltic andesite flows (Fig. 2a,b). These flows form a broad platform that is inferred to underlie the study area. In the northeast quarter of the study area at least $200 \mathrm{~m}$. 


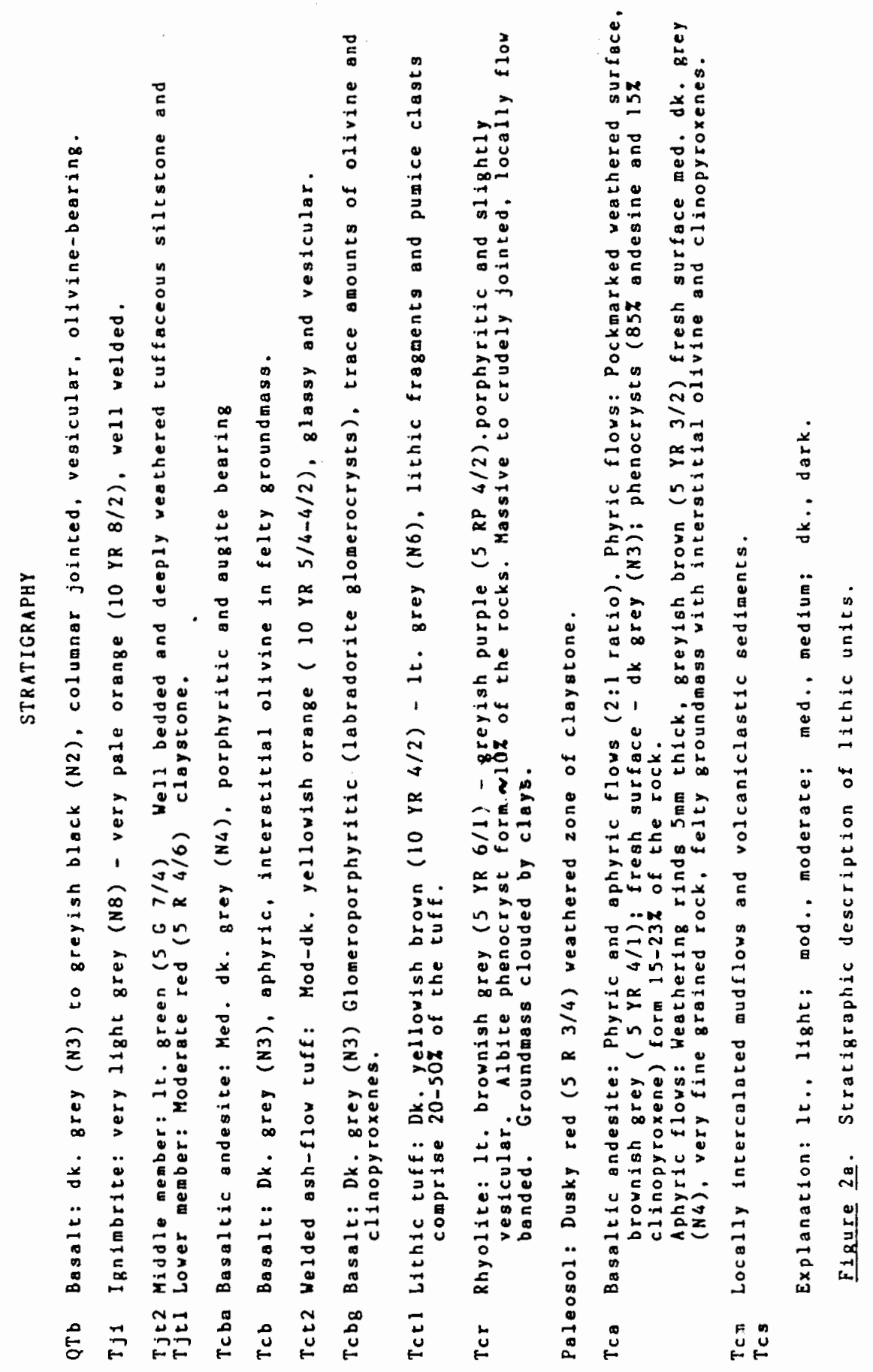




\section{STRATIGRAPHY}
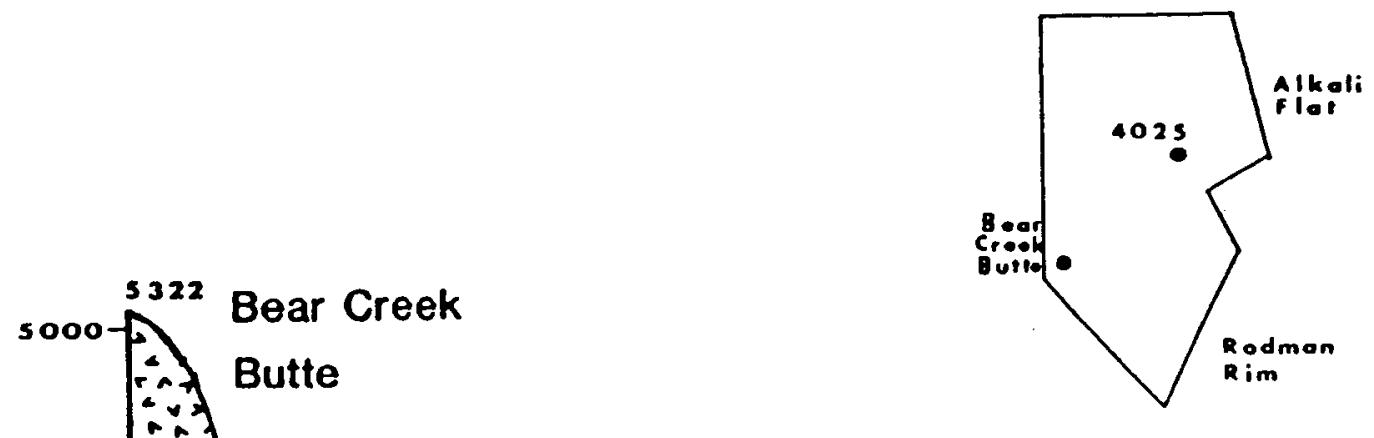

\section{Rodman Rim}

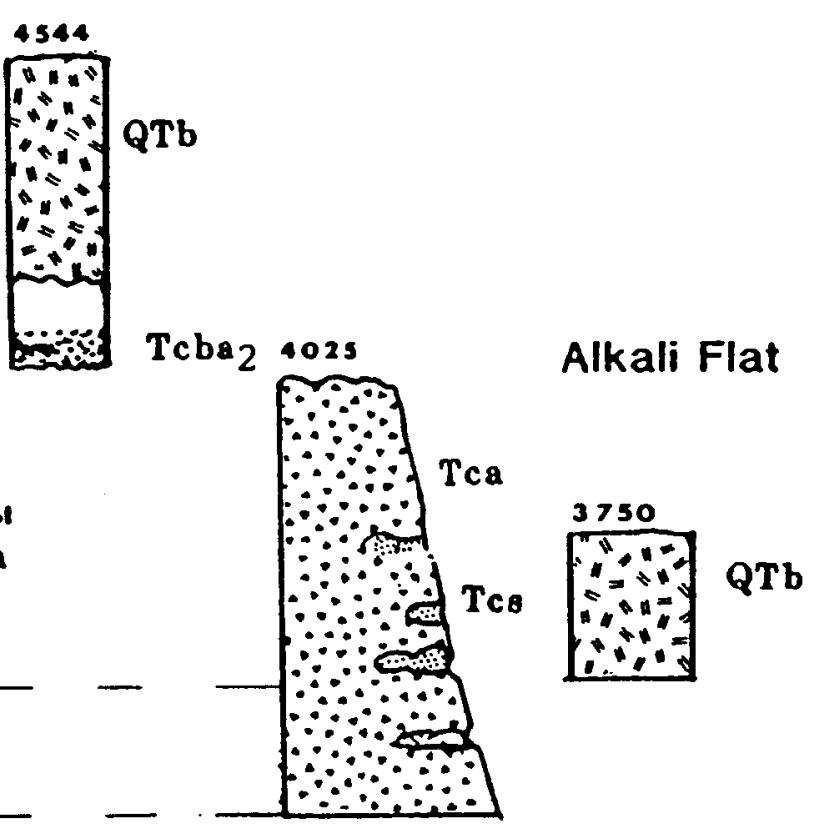

Figure 2b. Stratigraphic columns of Bear Creek Butte, Rodman Rim, andesitic vent, and Alkali flat. 
of flows have been measured. Inferred from flow banding, thickness and dip of the flows, and topography, these flows were deposited in a vent area. The flows have an average thickness of $3 \mathrm{~m}$. and range from 1 to 5 meters.

Both phyric and aphyric flows are present with the phyric flows being more abundant. The porphyritic 1avas genera11y display blocky to crudely platy jointing. Phenocrysts of olivine and plagioclase are differentially weathered from the groundmass producing a pockmarked surface. The rocks are easily broken into pea-size scree. The porphyritic flows erode more rapidly than the nonporphyritc flows and where capped by nonporphyritic flows, form steep slopes covered by fine scree.

The phenocrysts, forming $15-25 \%$ of the rock, are predominately fine to medium-grained subhedral plagioclase crystals with a subordinate amount of anhedral clinopyroxene. These phenocrysts occur in a felty groundmass of $0.1 \mathrm{~mm}$ subhedral plagioclase 1 aths. The plagioclase phenocrysts are andesine, An ${ }_{48}$, based on an average of the An content of 15 crystals that were examined using the Micheal-Levy method. They are compositionally zoned and occasionally exhibit Carlsbad twinning.

The nonporphyritic flows, though less numerous, are more prominent because they form the larger cliffs and ledges in the study area. These flows are massive to blockily jointed. The outcrops are commonly fractured. 
Fractures are coated by limonite.

Hand samples of the aphyric flows reveal few mineralogical or textural details. Sparse plagioclase crystals are visible through a handlens. In thin sections these crystals are $2 \mathrm{~mm}$ long and form less than $10 \%$ of the rock. The plagioclase is of labradorite composition, An, based on the average of four Micheal-Levy determinations. They are subhedral to euhedral exhibiting compositional zoning. In thin sections the texture consists of a felty groundmass of plagioclase laths that form $70 \%$ of the rock. The rims and cleavage planes of these laths are commonly corroded by clays (kaolinite) and carbonates. Fine grained anhedral olivine and/or clinopyroxene form $5 \%$ of the groundmass. The olivine is commonly corroded by alteration rinds of iddingsite and/or chlorophaeite. The remainder of the groundmass, $15 \%$, is composed of iron oxides, as hematite and magnetite, and kaolinite.

Intercalated with these flows are several mudflows (Fig. 2b). These are composed of subangular to subrounded cobbles and boulders of basaltic andesite. These cobbles and boulders are randomly distributed in a matrix of sand and mud. Carbonized wood fragments are also found in the mudflows. For a few of the smaller mudflows the paleochannel through which the lahars flowed can be seen in cross section; including an irregular floor and steep sides. The paleochannel walls of a large mudflow in the 
southeastern portion of the study area (P1ate 1) are not exposed. A stream has dissected this lahar which now forms cliffs 5-10 meters in height.

Several outcrops of volcaniclastic sediments are found around the flanks of the basaltic andesite platform (Plate 1). The sediments commonly contain fine to medium grained subangular to subrounded basaltic andesite lithic fragments, feldspars, and trace amounts of quartz. These sediments exhibit crude to well developed bedding with cross bedding in some areas. Sparse leaf fossils were found in these sediments and were previously described by Mote $(1940)$.

Stratigraphical1y above the basa1tic andesite flows is a dark red clayey paleosol (Fig. 2a,b). The paleosol varies in thickness from 0 to 3 meters and is most widespread in the area of the Wiltze homestead and west of the Tingley ranch (Fig. 1).

Rhyolite flows of the upper sequence form two domes in the area, Bear Creek and Taylor Buttes. Associated with these domes are two felsic tuffs and several basalt flows of low volume (Fig. 2b).

The rhyolite crops out as jointed to massive outcrops forming numerous bluffs and scree on the buttes. The rhyolite exhibits well-developed flow banding both in hand samples and thin sections. This flow texture forms a prominent slope on the south side of Bear Creek Butte, 
dipping as great as $18^{\circ} \mathrm{SW}$.

Though the color of the rhyolite that forms the two buttes varies, the mineralogy is uniform. The rhyolite is porphyritic and slightly vesicular. Vesicles are commonly encrusted with limonite/hematite and occasionally filled with coarse grained quartz. Phenocrysts compose less than $10 \%$ of the rocks. These phenocrysts have been determined to be euhedral to subhedral crystals of albite, An, using the Micheal-Levy method. Albite twinning is common in the plagioclase phenocrysts. The phenocrysts appear to be relatively unaltered compared to the groundmass which is usually clouded by very fine grains of clay. Several microfractures are present in thin section. These fractures cross the phenocrysts and are commonly rehealed by very fine grained quartz. Since no alteration halos are associated with these rehealed fractures, they probably represent a cooling phenomenon of the rhyolite flows.

Basalt flows are located on the lower slopes of the buttes (Plate 1). The basalts are generally a dark grey porphyritic rock that forms low, fractured, rounded, knobby outcrops (Fig. 2a). Iron staining is prevalent along these fracture surfaces. Aphyric basalt flows are also present and form similar outcrops (Fig. 2a).

In phyric flows, the phenocrysts occur in glomerocrysts containing plagioclase with trace amounts of olivine and/or pyroxene. These phenocrysts are supported 
in a felty groundmass of very fine grained plagioclase laths with interstitial clinopyroxenes. Based on the analyses of $20+$ crystals the glomerocrysts are composed of labradorite, An 51. These crystals which are subhedral to euhedral have better developed crystal forms than the laths in the groundmass. One third of the plagioclase phenocrysts are compositionally zoned and twinning is rare. All the olivine crystals are finely fractured anhedral crystals. These crystals are commonly altered to iddingsite.

The aphyric basalts exhibit no textures in hand sample. In thin sections however, a prominent felty texture of plagioclase laths with finer interstitial anhedral grains of olivine and/or clinopyroxene are visible. Opaques, probably magnetite, comprise $10 \%$ of the rock. Crude alignment of the plagioclase laths is visible in thin section. The rims of these laths have been corroded.

Two felsic tuffs are exposed on the flanks of Bear Creek Butte. A welded air fall tuff located north of the old Wiltze homestead (Plate 1), underlies a ridge crest and knob in that area. This tuff forms prominent jointed to massive cliffs at these locations (Fig. 2a). The rock is very glassy appearing in hand sample. Vesicles are visible throughout the outcrops of this tuff but are more numerous in the upper one-third of the unit. Fifty percent of the 
vesicles are filled with secondary quartz. No flow direction can be determined in the field but its spatial distribution suggests a close relationship with Bear Creek Butte. In thin section the outlines of glass shards and small pumice clasts are preserved although the glass is devitrified. The pumice clasts have been flattened and are bounded in the welded devitrified matrix.

The tuff that lies to the south (Plate 1) is mapped as a seperate tuff based on the large percentage of lithic fragments and pumice clasts (Fig. 2a) contained in this unit which Ross and Smith (1961) and Hildreth and Mahood (1985) indicate are reliable criteria for differentiation. The varying percentage of the lithic and pumice fragments produce variations in the color of the tuff. The more distal portion of the ash flow unit has fewer lithic fragments and the pumice clasts are smaller and more rounded. The fragments and clasts are crudely aligned in a subhorizontal manner. Where the inclination of the clasts are consistent, the dip is away from Bear Creek Butte suggesting a flow direction away from the butte.

Overall this tuff is moderate-to we11-indurated. It forms major ridges in the vicinity of the Platner mine where it has been faulted, brecciated, and silicified. Further to the south the tuff forms resistant caps on the knobs in the area of the Admunsen claim.

The tuffs of the Clarno Formation are quite dissimilar 
from the overlying John Day tuffs that crop out in the study area. These tuffs lack the distinct coloring characteristic of John Day tuffs. Also the chemical and physical composition of the Clarno and John Day tuffs are quite different. The tuffs of the Clarno contain more pumice clasts and 1 ithic fragments and are more indurated. The tuffs of the John Day are composed primarily of airfal1 debris that has since been altered to claystone and siltstone. The ash flow tuff associated with the John Day Formation in this area is lacking in lithic or pumice fragments.

Cropping out in the southern corner of the study area, on the upper slope of the Rodman Rim is an augite-bearing basaltic andesite. A thin section indicates that the rock contains augite phenocrysts and a few plagioclase phenocrysts in a felty matrix (Fig. 3). This flow is inferred to be stratigraphically above the other units of the Clarno based on it position on the slope.

The stratigraphic relationship of the units among the upper sequence of the Clarno Formation is quite complex. The low volume basalt flows overlie both tuff units. West of the Tingley ranch the lower lithic rich tuff contains billiard ball size clasts of rhyolite from Bear Creek Butte. This indicates a complex history of pyroclastic eruptions associated with development of domes and eruption of basalt flows from the flanks of these domes. The 


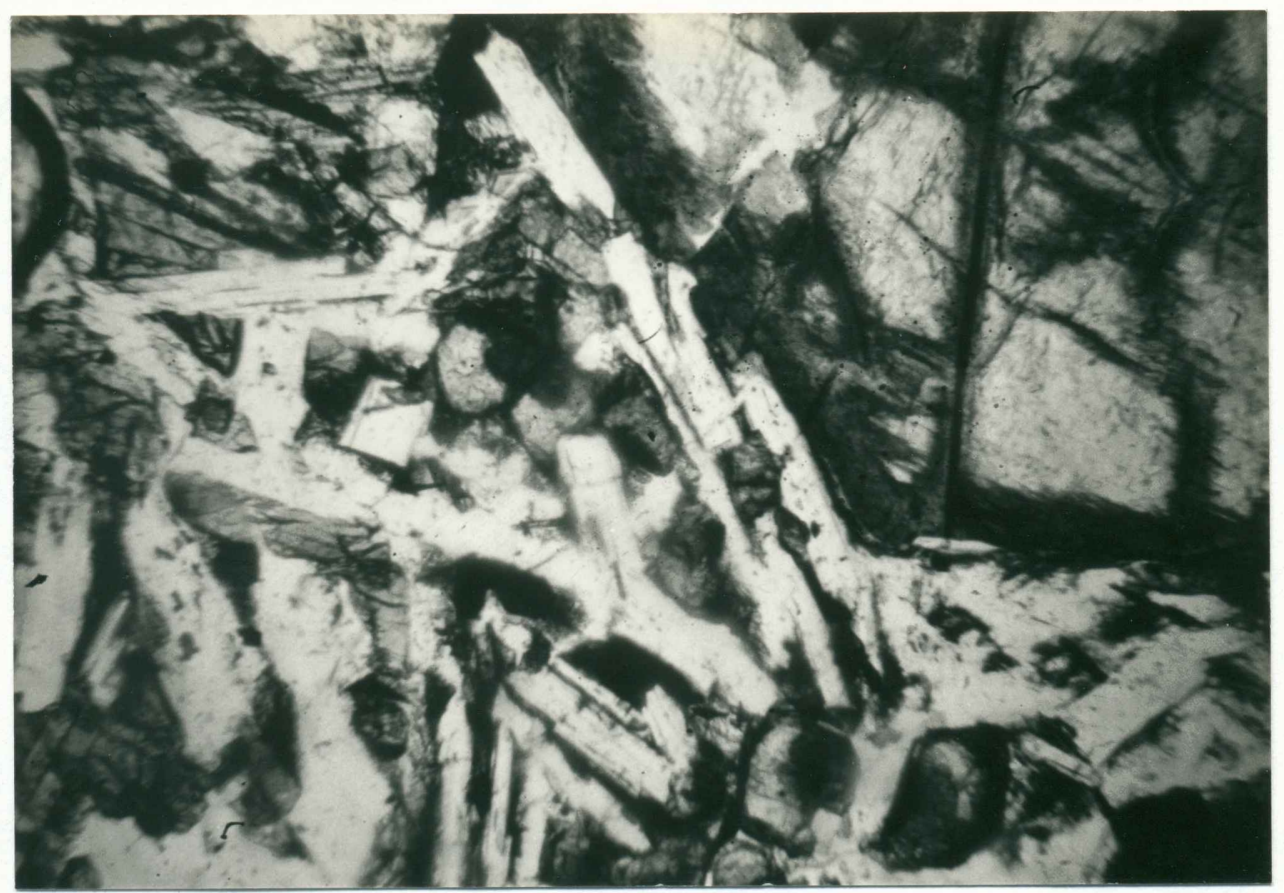

Figure 3 . Photomicrograph of augite-bearing andesit $\bar{e}$.

basaltic andesite found on Rodman Rim may be stratigraphically above the tuffs and basalts but appears to be unrelated to the development of the domes and flows.

\section{John Day Formation}

The John Day Formation is composed of felsic pyroclastic debris of airfall origin which originally blanketed the country side (Fig. 2a). These deposits were washed from the hillsides into local basins, (Peck, 1961, 1964). An outlier of the John Day Formation crops out southeast of Bear Creek Butte (P1ate 1). Less resistant to weathering than the overlying and underlying units, the 
John Day Formation forms slopes and low ridges in its outcrop location. The John Day Formation rests with angular discordance on the upper Clarno rhyolite and the dark red saprolite which mantles the lava flows of the lower Clarno. This saprolite is overlain by dark reddish brown tuffaceous claystones and siltstones of the John Day Formation. Due to color and lithologic similarities the contact between the two units is difficult to determine and was drawn at the topographic break in slope between the more resistant lower volcanics and the overlying soft tuffaceous sediments.

Within the study area the John Day Formation consists of three members. The lower member is a 10 meter thick dark redish tuffaceous claystone and siltstone. The thicker (15-20 m) middle member is composed of a pale green tuffaceous claystone and siltstone. These sediments are well-bedded. Beds of varying color and locally more resistant layers that form ribs and thin ledges accent the bedding. These sediments are deeply weathered with a welldeveloped mudcracked mantle; the result of montmorillonitic clays in the tuffs (Hay, 1962).

The tuffaceous sediments are capped by an air fall tuff unit, probably correlative to Hay's (1962) ignimbrite of the middle John Day Formation based on stratigraphic positon, mineralogy and texture. This unit is $2-5 \mathrm{~m}$ thick and consists primarily of an aphanitic matrix which 
contains sparse feldspar phenocrysts and pumice clasts.

High Lava Plains basalts

The impressive cliffs and ledges to the east and south of Bear Creek Butte (Plate 1) are formed by outcrops of basalts which underlie the High Plains. Basalt flows located $24 \mathrm{~km}$ to the south near the town of Millican have been dated at $6.7 \mathrm{~m} \cdot \mathrm{y} \cdot \mathrm{a}$. (Walker and Swanson, 1969;

Fiebelkorn and others, 1983). These basalts are informally named the Sage Hollow basalts. The basalts that formed Alkali Flat, due east of Taylor Butte, are assumed to be more recent. This is inferred from the undissected form of the cinder cone of Alkali Butte, located $8 \mathrm{~km}$. east of the study area, that was the source of these basalt flows. Based on the lower elevation of the basalt flows at Alkali Flat it is inferred that these flows filled a topographic low north of the flows that formed Rodman Rim.

The basalt flows covered much of the pre-existing topography with a series of widespread lava flows (Walker, 1974). Comparing the elevations of the tops of these flows and that of the domes it is apparent that the domes were not completely covered by the basalt (Fig. 2b).

From a distance the flows are a dusky blue. In hand sample the rock is medium dark grey (N4). Columnar jointing is prevalant and well-formed columns up to 1.5 meters in diameter are common. Steep scree of fragmented columns are formed below the cliffs, covering the 
underlying lithologies.

Although the basalt flows that form Alkali Flat and Rodman Rim appear not to be age equivalent they appear quite similar in thin section. The basalt is highly vesicular. A few of the large vesicles are lined with secondary zeolites. Olivine crystals are scattered through the felty groundmass composed of plagioclase laths and pyroxenes. The olivine is partially to fully altered to iddingsite.

\section{Alteration mineralogy}

The distribution of hydrothermally altered areas in the study area is widespread but scattered. However, the most extensively altered areas are located along NW-NNWtrending fault zones. The largest and most intense areas of alteration are the sites of the Platner and Oronogo mines and the Admunsen claim (Plate 2). The hydrothermal alteration mineralogy includes quartz and trace amounts of chalcedony, as well as kaolinite and smectite, iron oxides and trace amounts of sulfides. The mineralogy that characterizes the zones of hydrothermal alteration is listed in figure 4. The distribution of this alteration mineralogy is plotted on plate 2. The locations of samples analyzed by $x$-ray diffraction or instrumental neutron activation are plotted on plate 2 and chemical data is listed in appendix $C$. 
The three divisions of the hydrothermal alteration in figure 4 are based on a composite of work by Lindgren (1933) and modified by Buchanan (1981) and Giles and Nelson (1983). In this scheme weak hydrothermal alteration corresponds to propylitic alteration; an assemblage of chlorite, pyrite, carbonate, montmorillonite, and illite. A low pH assemblage of kaolinite, sericite, montmorillonite, and illite comprise the moderate a1teration zone. The strongly altered area is distinguished by intense silicification. These assemblages form a pattern of diffuse overlapping zonation in the study area.

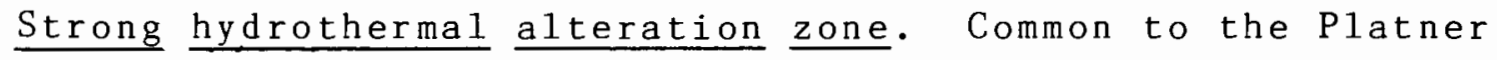
and Oronogo mines and the Admunsen claim is a central area of silicification, enclosed by a kaolinite +/- smectite zone that grades outward to an area of weak alteration (Fig. 5, 6 and 7). The zones of intense silicification are elongated along the strike of steeply dipping faults. This zone varies in width, from $<3 \mathrm{~m}$. at the Oronogo mine to $>10$ m. at the Platner mine, and is characterized by pervasive silica flooding and replacement of the host rocks by fine grained quartz.

Within the silicified zones are areas of breccia. These breccias consist of subangular to subrounded rock fragments ranging up to $.25 \mathrm{~m}$. in diameter. The breccias have been cemented and sealed by very fine grained quartz. 

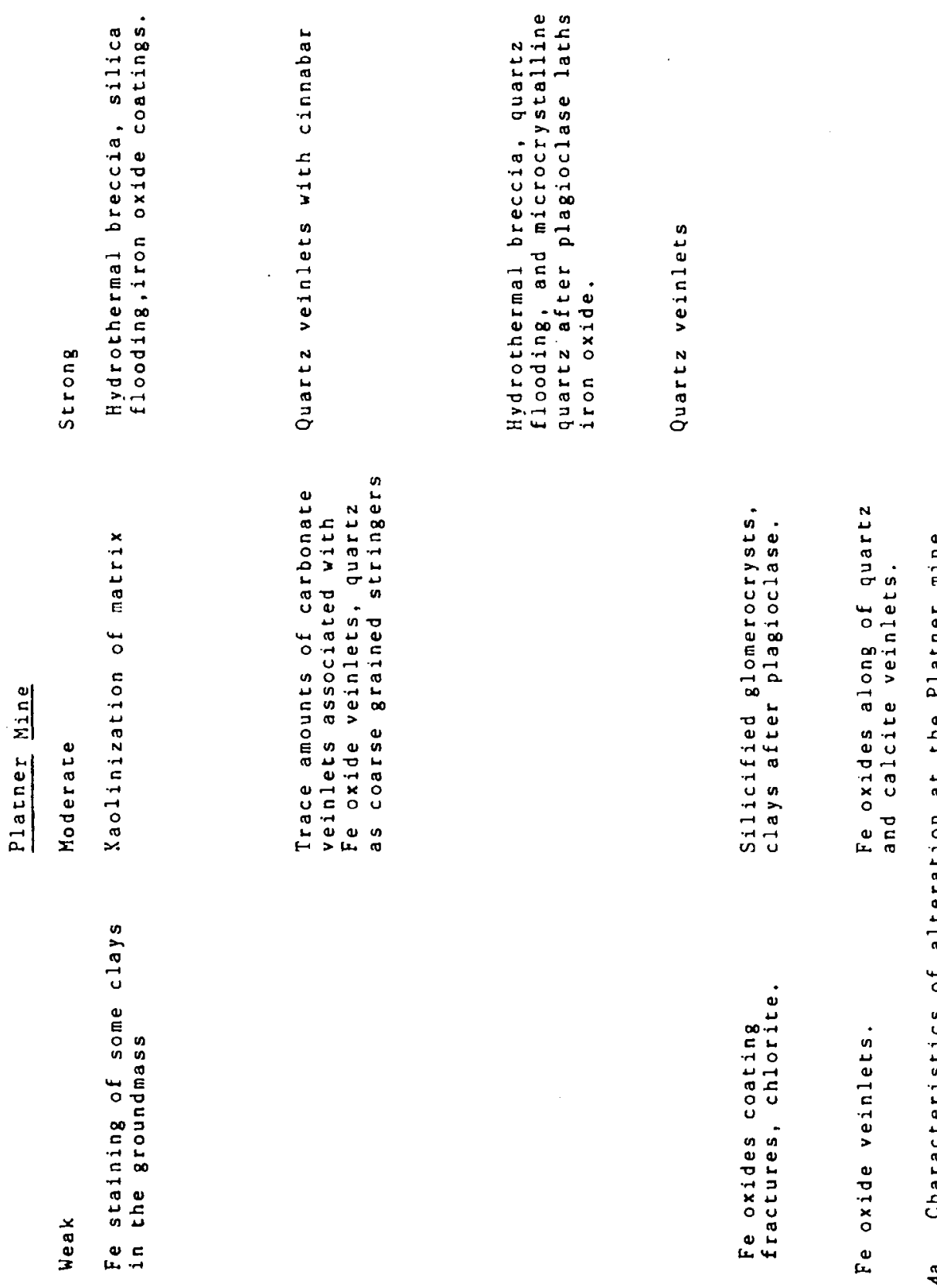

[d]

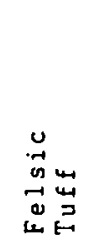

$d x d$

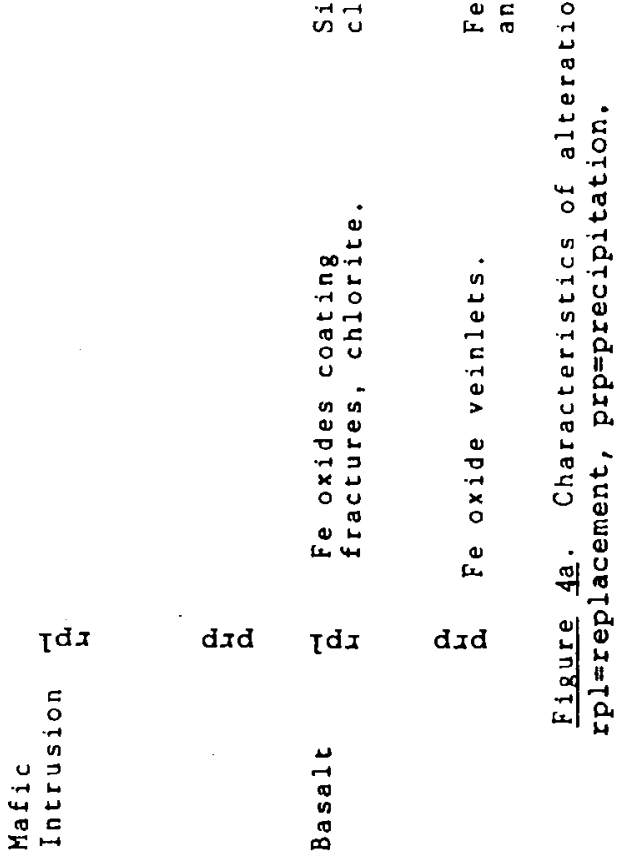
0 

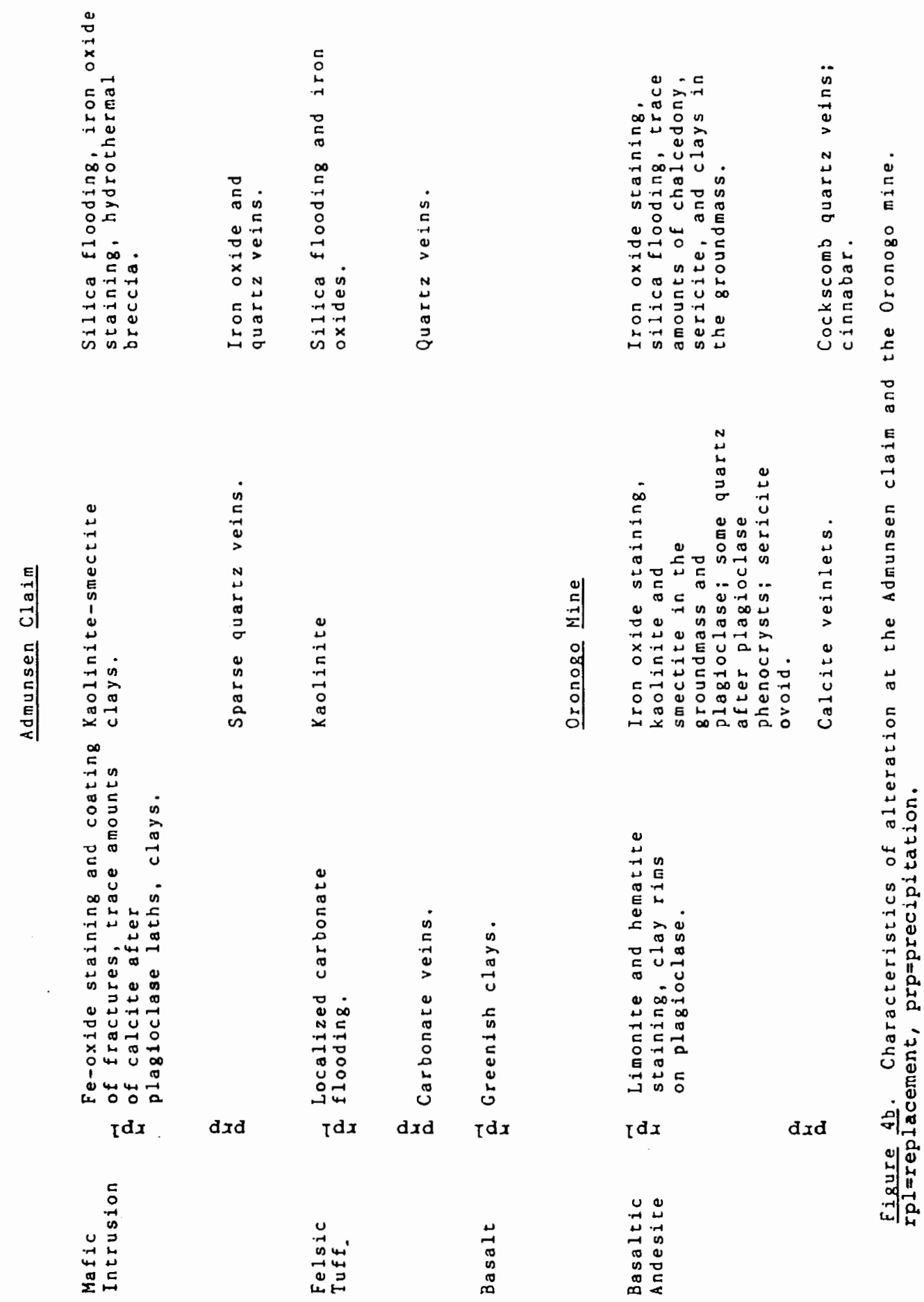
Platner MIne

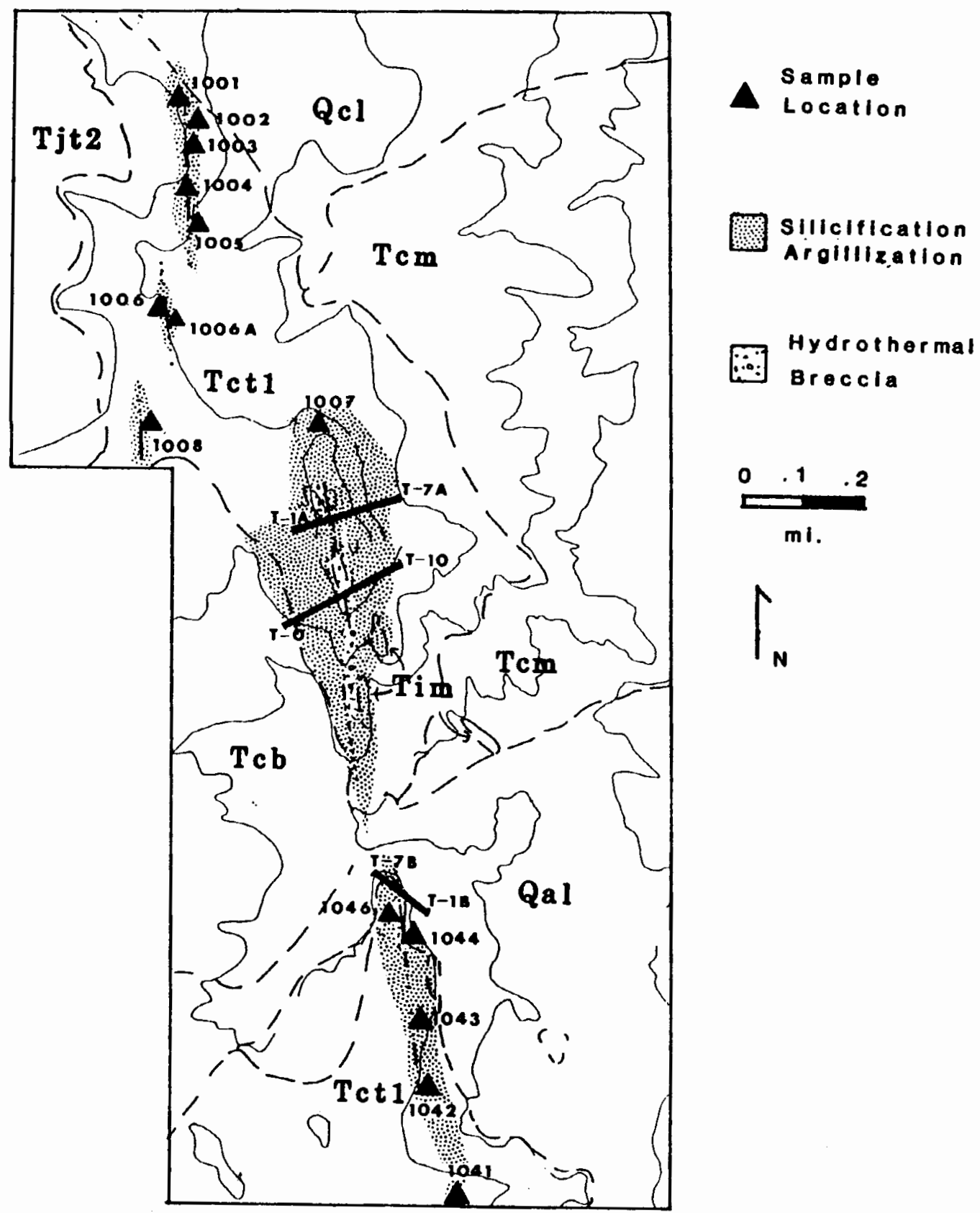

Figure 5. Map of the Platner mine. 
$\frac{5}{6}$
5
8
5
8
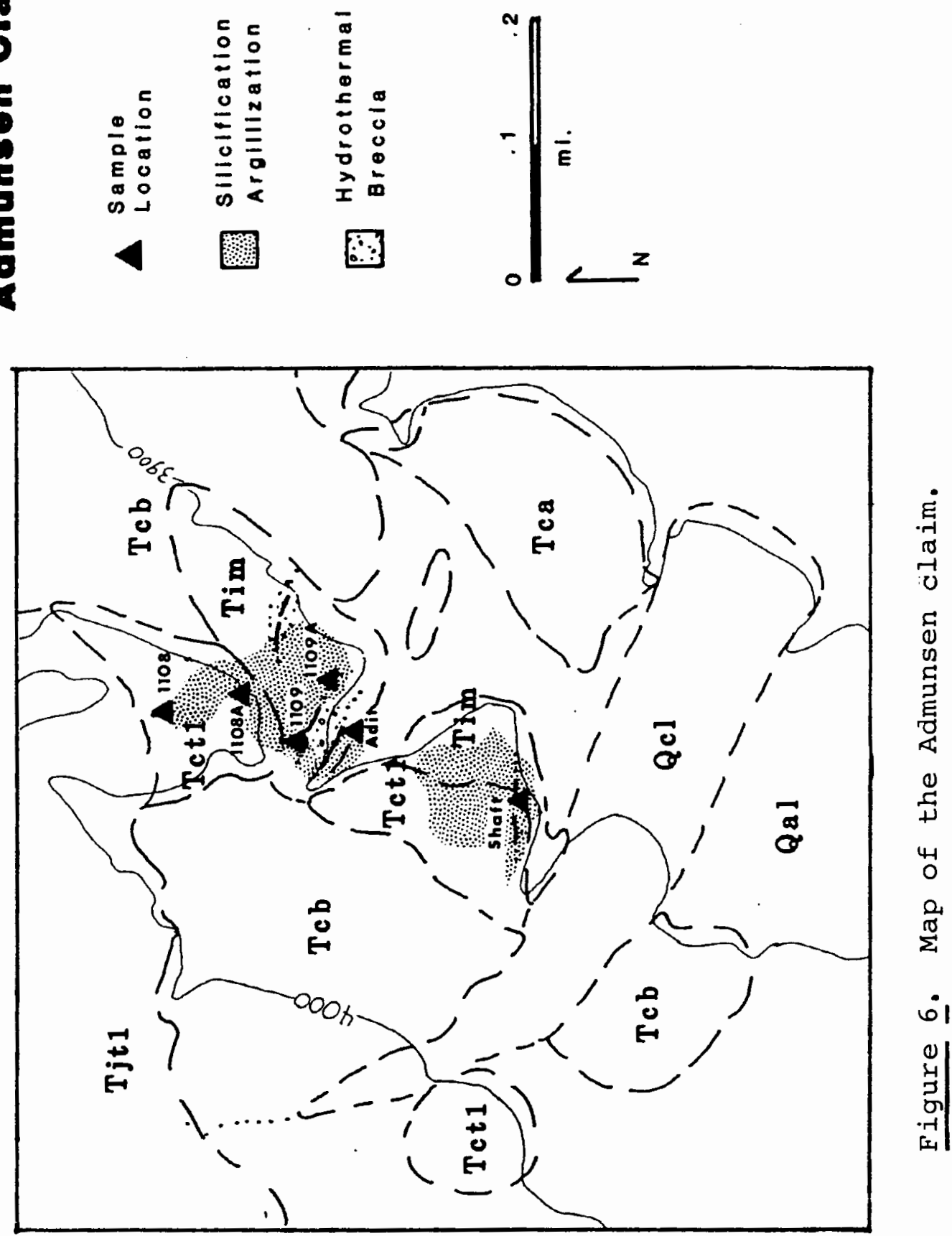


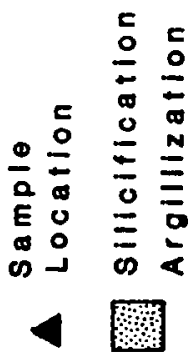

6
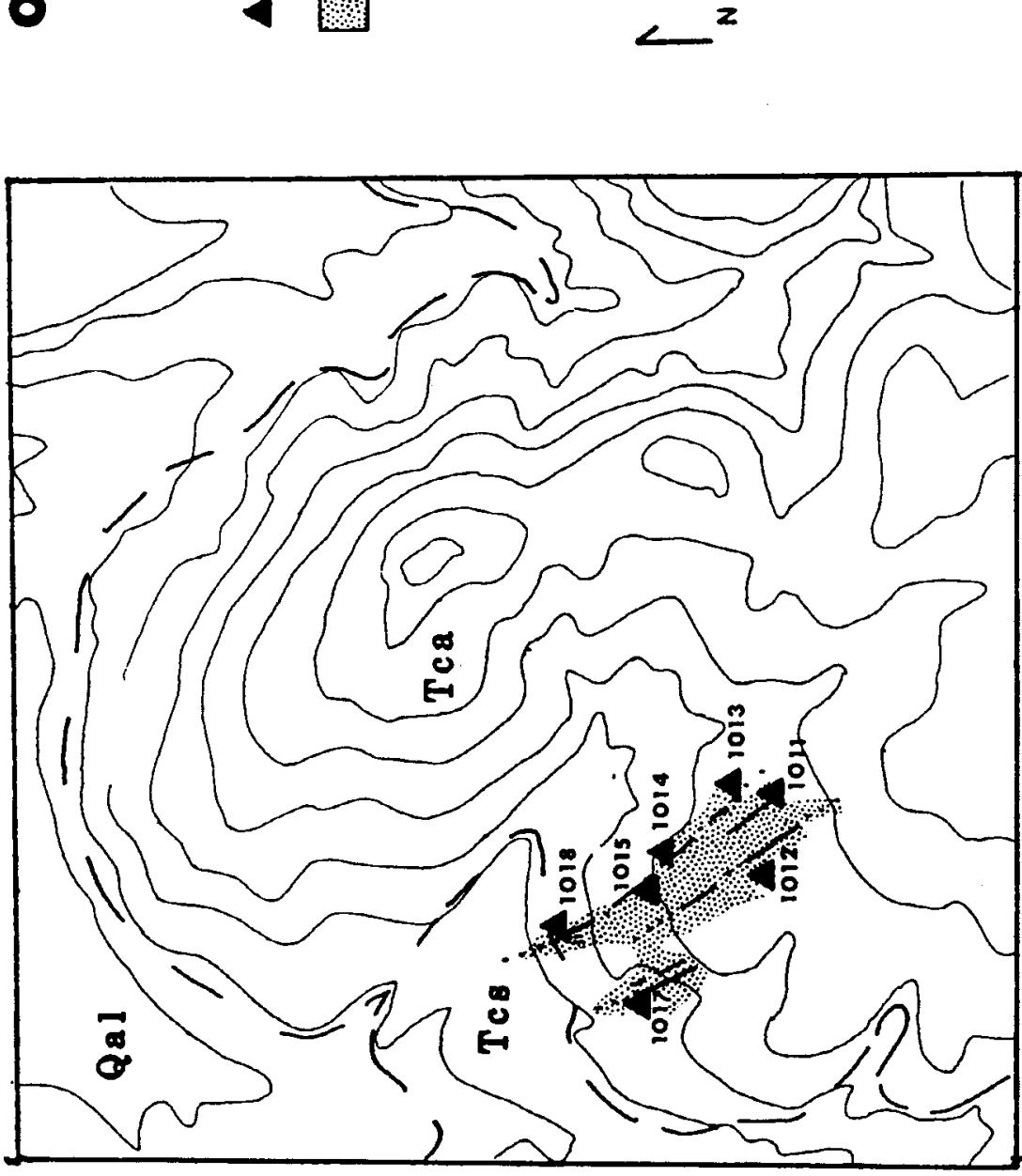

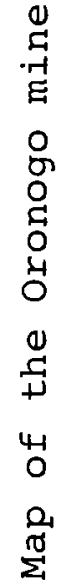
-1
0
0
3
0
-7
$[1$ 
Although irregular in shape the areas of breccia are not randomly distributed. At the Platner mine the areas of brecciation are associated spatially with the mafic intrusions (Fig 5). The brecciated rocks in these areas include the felsic tuff, mafic intrusion and previously brecciated fragments. At the Admunsen claim breccias are located along a zone of faults trending $\mathrm{N} 55-85^{\prime} \mathrm{W}$ (Fig. 6). A felsic tuff and mafic intrusion comprise the breccia fragments.

At the Platner mine silica flooding of the host rocks, a felsic tuff and a mafic intrusion, has formed resistant knobs and ridges that stand in high relief above the surrounding areas. The silica has replaced the groundmass of the host tuff as well as pumice clasts and 1 ithic fragments contained in the tuff. A mafic intrusion crops out exclusively in the strongly altered zone (Fig. 5). A11 minerals in this intrusion have been replaced by quartz (Fig. 8). However, the skelatal outlines of the plagioclase laths and other primary textures are preserved locally, allowing identification of the original rocks. Iron oxides are also present in the altered intrusion as blebs in the groundmass. Some of the oxides are replacements of pyrite, as inferred from the cubic form seen in thin sections. The breccia in this zone is usually cemented by fine quartz grains or occassionally chalcedony. 


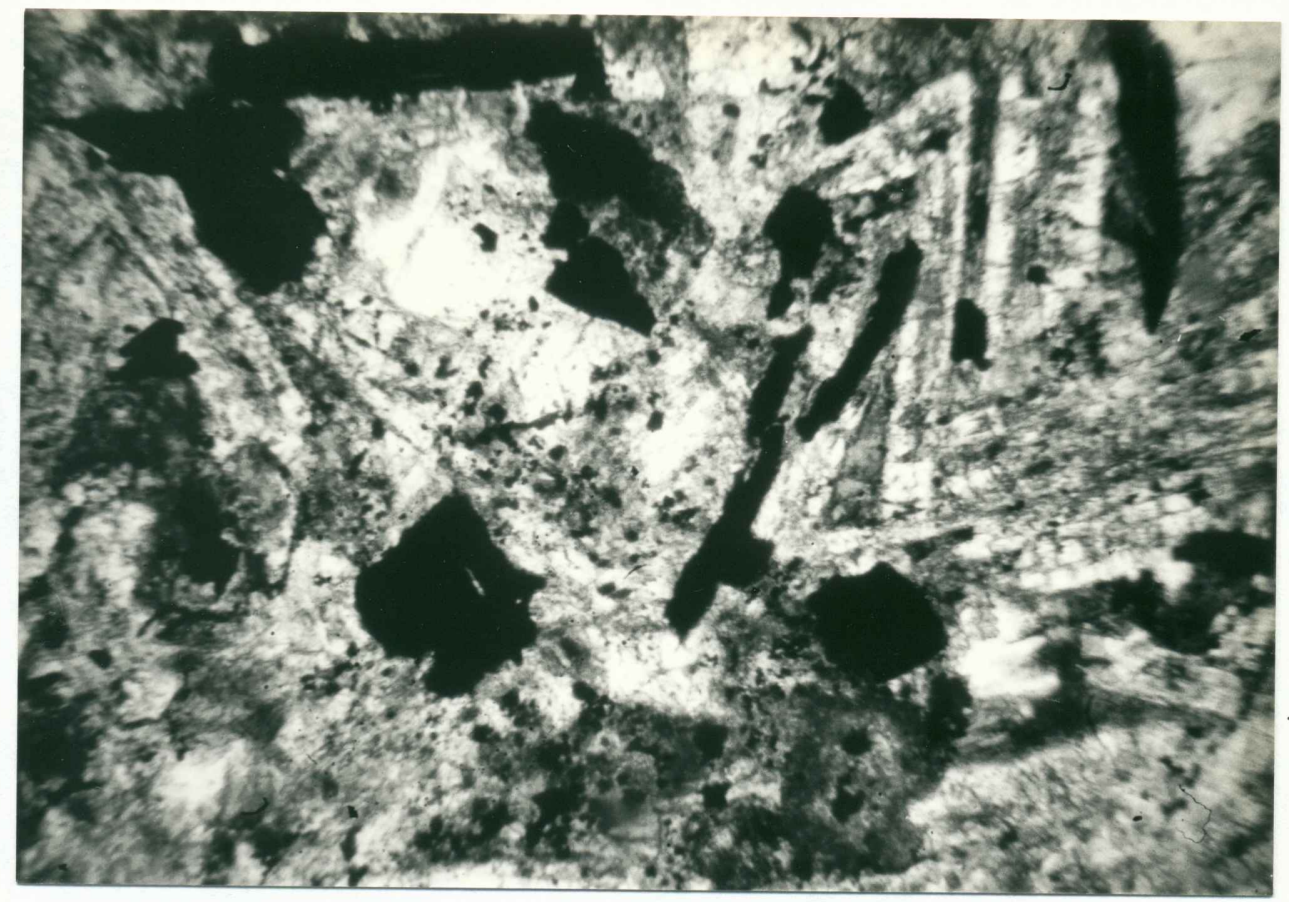

Figure 8. Photomicrograph of altered mafic intrusion.

Veining is another common feature within the zones of strong hydrothermal alteration (Fig. 3a,b). The veins are narrow, less than $2 \mathrm{~cm}$. in width and are composed of very fine grains of quartz that completely fill the fractures. Cinnabar also occurs in these veins as scattered blebs. They are present in al1 strongly altered rock units and cross 1ithologic boundaries.

At the Admunsen claim the zone of strong hydrothermal alteration is similar in alteration mineralogy and manner of replacement to that at the Platner mine (Fig. 3a,b). Pervasive silicification in the form of very fine grained quartz is the dominant alteration mineralogy. The area of 
silicification is widespread $(10 \times 20 \mathrm{~m}$.$) but is centered$ around W-NW-trending faults (Fig. 6). Limonite and hematite are common alteration materials in this zone. They occur as blebs, coatings and veinlets, commonly in such quantity as to completely obscure primary textural and mineralogica 1 relationships. The veinlets are small, less than $2 \mathrm{~cm}$ wide, and composed of quartz as well as iron oxides.

At the Oronogo mine the host rock is porphyritic basaltic andesite. The zone of strong alteration is restricted to narrow, $<3 \mathrm{~m}$. wide, elogate zones (Fig. 7), paralleling the strike of the faults in this area.

Hydrothermal breccia is absent. Silicification ranges from partial to complete replacement of the host rocks by very fine grained quartz with trace amounts of clay (Fig. $3 b$ ). The skeletal outlines of the plagioclase laths of the primary igneous texture are frequently retained after silicification. Quartz fills nearly all the veins in this zone. The forms of the vein quartz varies from cockscomb growth along the vein walls to subhedral quartz grains that completely fill the veins. These veins are narrow, rarely exceeding $2 \mathrm{~cm}$. in width and relatively straight. They cut the basaltic andesite and generally are subparalle1 to the faults cutting the host rocks. The cinnabar found at the Oronogo mine is located in these veins.

Moderate hydrothermal alteration zone. The transition away 
from the silicified core to the zone of moderate hydrothermal alteration is gradational as the ratio of clay to quartz increases. This zone in characterized by kaolinization (Fig. 3a,b). At the Oronogo and Platner mines the distribution of the zone of moderate alteration is skewed to the west i.e. the hanging wall, of the local fault trend; forming a lopsided elipse around the silicified cores (figs. 5 and 7 ). In the area of the Admunsen claim a similar distribution is not evident (Fig. 6).

At the Platner mine the zone of moderate hydrothermal alteration is characterized by kaolinization of the felsic tuff (Fig. 3a). Limonite and hematite accompany the kaolinite. These iron oxides are prevalant throughout the area as fracture coatings and pervasive staining of the kaolinized groundmass. The limonite and hematite also appear as coatings on veinlet walls, in a few instances completely filling the veinlets. Locally, areas of quartz stringers and calcite veinlets are present.

Isolated outcrops of the overlying glomeroporphyritic basalt are found in the zone of moderate alteration. In these outcrops the glomerocrysts have been silicified by very fine grained quartz and individual phenocrysts have been replaced by iron oxides. Fine veinlets of quartz and of calcite have sealed fractures in the basalt.

At the Admunsen claim smectite occurs with kaolinite 
in the zone of moderate alteration (Fig. 3b). These clays have completely replaced the mineralogy of the mafic intrusion and felsic tuff in several areas, most notably at the mouth of the main adit. These clays are also associated with silica flooding and quartz veining in the gradational transition area between the strongly and moderately altered zones.

Limonite and hematite also occur in this zone. Where occuring with the clays as blebs and fine grains, the iron oxides obscure all textural relationships in the rock. Limonite and hematite also occur as coatings on fracture wa $11 \mathrm{~s}$.

The zone of moderate hydrothermal alteration forms a narrow halo about the strongly altered zone at the Oronogo mine (Fig. 7). The zone rarely extends more than $1.5 \mathrm{~m}$. beyond the contact with the silicified core.

Kaolinite replaces both the groundmass and to a lesser degree the plagioclase phenocrysts of the basaltic andesite host (Fig. 3b). Thin sections reveal ovoids formed by very fine sericite grains after some of the plagioclase 1 aths. Kaolinization occurs with silicification in some areas where plagioclase phenocrysts have been replaced by quartz and the groundmass by kaolinite. Veins in this zone are completely filled by quartz or calcite.

Weak hydrothermal a1teration zone. The zone of weak hydrothermai alteration forms an irregular halo around the 
periphery of the zone of moderate alteration. At the Platner mine this zone is characterized by partial alteration of the lithic tuff by kaolinite (Fig. 3a). In these areas the groundmass has been patchily altered and the pumice clasts are rimmed by clay. However, the lithic fragments are unaffected by alteration. Iron oxide stainings and coatings also occur but without the intensity found in the inner zones. The iron oxide also occurs in the basalt as fracture coatings and in fine veinlets. The pyroxenes in the basalt have been partially altered to chlorite.

At the Admunsen claim the weak alteration zone is characterized by localized argillic alteration and carbonate veining (Fig. 3b). Hematite and limonite occur as fracture coatings and stainings in the mafic intrusion and felsic tuff. Locally calcite partially replaces the groundmass of the felsic tuff and forms fine veinlets in this tuff.

In this weak alteration zone at the 0ronogo mine plagioclase phenocrysts are rimmed by clays (Fig. 3 b). Limonite and hematite coatings of fracture surfaces and staining of the groundmass occur but to a lesser degree than in the inner zones. Calcite stringers can be identified in thin section but are rare. 


\section{Uranium prospects}

Numerous exploration pits are located along the NWtrending ridges in the NE $1 / 4$ of $\mathrm{Sec} .24$ south of Bear Creek Butte (P1ate 2). These pits are remnants from the uranium boom in the mid 1950's (Schafer, 1956). The pits are astride NW-trending faults that cut the John Day tuffs and the underlying rhyolite of Bear Creek Butte. Exploration trenches cut the faults perpendicularly to strike exposing altered areas. Clays, predominately kaolinite, fine grained quartz and trace amounts of chalcedony comprise the alteration mineralogy. Schafer (1956) reported the presence of yellow green fluorescent secondary mineralization coating fractures on the east wall of the main uranium show. On the opposite wall a green fluorescent secondary uranium mineral was disseminated in the tuff. However, these minerals were not observed in this study.

\section{Fumerolic alteration}

Numerous small isolated bleached and vuggy areas are found on the slopes of the two rhyolite domes, Bear Creek and Taylor Buttes. The rocks in these areas have been bleached chalky white and stand out against the dull purple grey color of the unaltered rhyolite. These areas are highly fractured and the fractured surfaces are commonly coated by dark reddish brown stain. These areas are not located along major fault trends as are the previously 
described areas.

One such area is exposed in a road cut on Taylor Butte along Route 27 (Plate 2). In this area fumerolic alteration has affected the rhyolite and the onlapping basalt. Characteristic of this area is the presence of a fiberous zeolite. The zeolite has formed fiberous, hairlike, needles that radiate into vugs and cavities in the rocks. These zeolite crystals have been analyzed by $x-r a y$ diffraction and identified as analcime. 


\section{CHAPTER III}

\section{GEOCHEMISTRY}

More than 100 samples were analyzed for major and trace elements. Twenty samples analyzed by XRF (Table I) were grab samples of relatively fresh rock. Of the approximate 100 samples analyzed by INAA, 50\% were bulk samples from the Platner and Oronogo mines and Admunsen claim. The remainder were grab samples from these and other areas. The location of the various samples are plotted on plate 2. X-ray diffraction analysis was of monomineralic separates and clays. Descriptions of analytical methods and analytical results are in appendices $A, B$, and C.

\section{Geochemistry of the Clarno Formation}

Overall, the Clarno Formation in Central Oregon, consists of an intermediate, high-alumina calcalkaline volcanic suite. The calcalkaline character of these rocks was determined by using an A-F-M plot (Fig. 9) modeled after Kuno (1960) and the classification guide of Irvine and Barager (1971). A Harker variation diagram (Fig. 11a) of A 10 vs SiO demonstrates the high-alumina 232 characteristics of the rocks in the study area; Al 0 


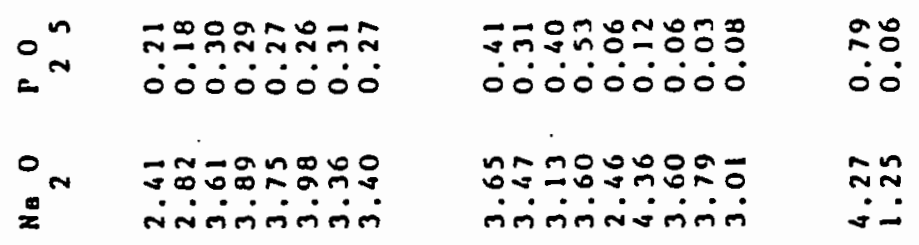

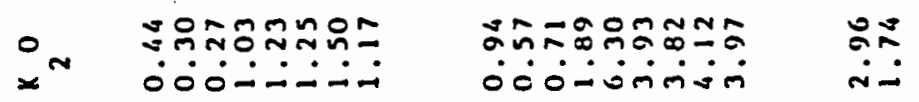

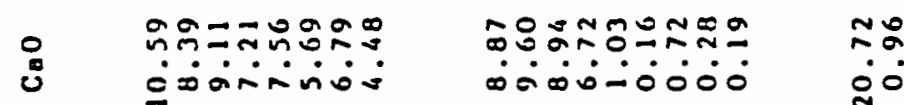

은 노ำํำ

I 00000000 0000000$\dot{0}$ 00

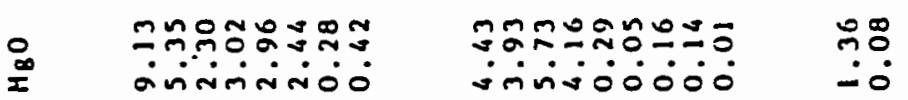

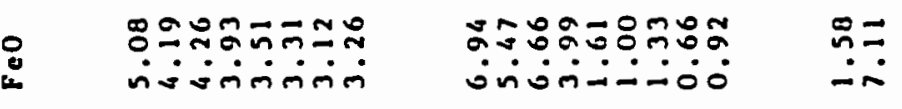

ஊ

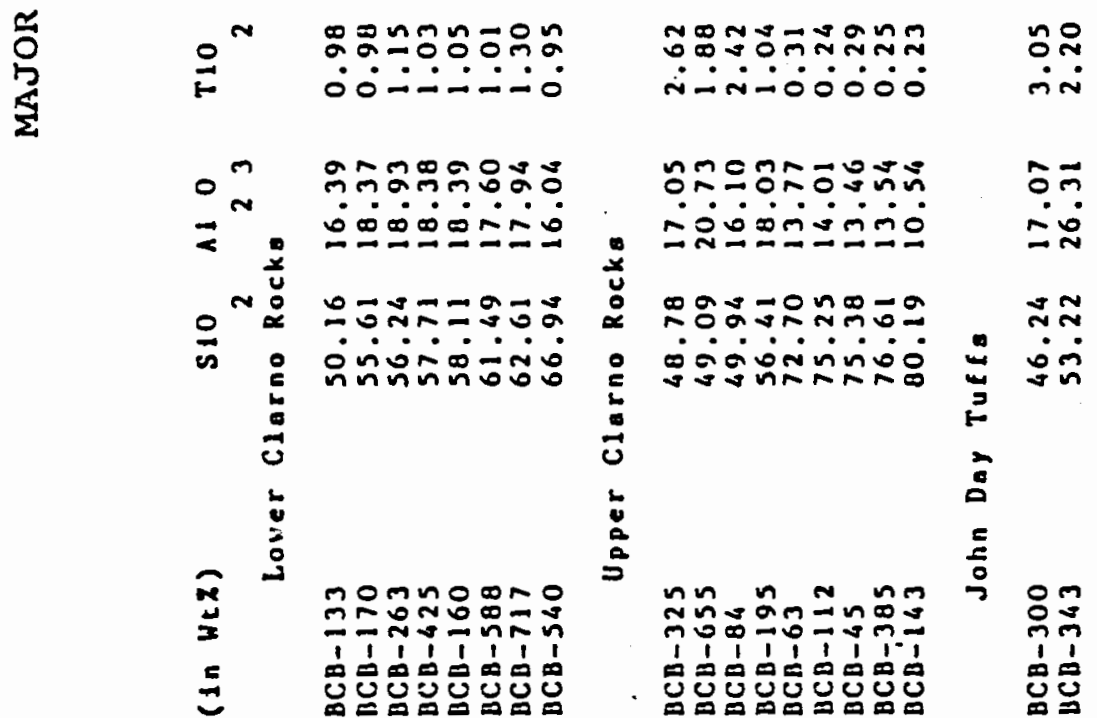




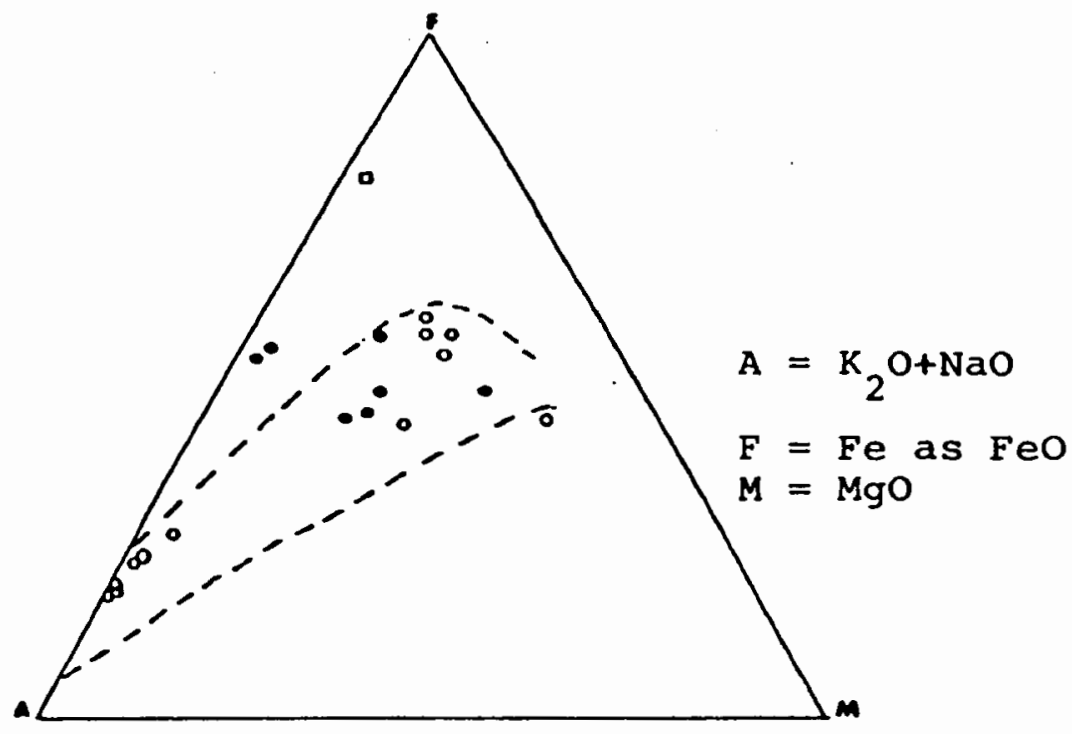

Figure 9. A-F-M diagram for Clarno and John Day rocks. Dashed lines show Kuno's (1968.) hyperthenic series.

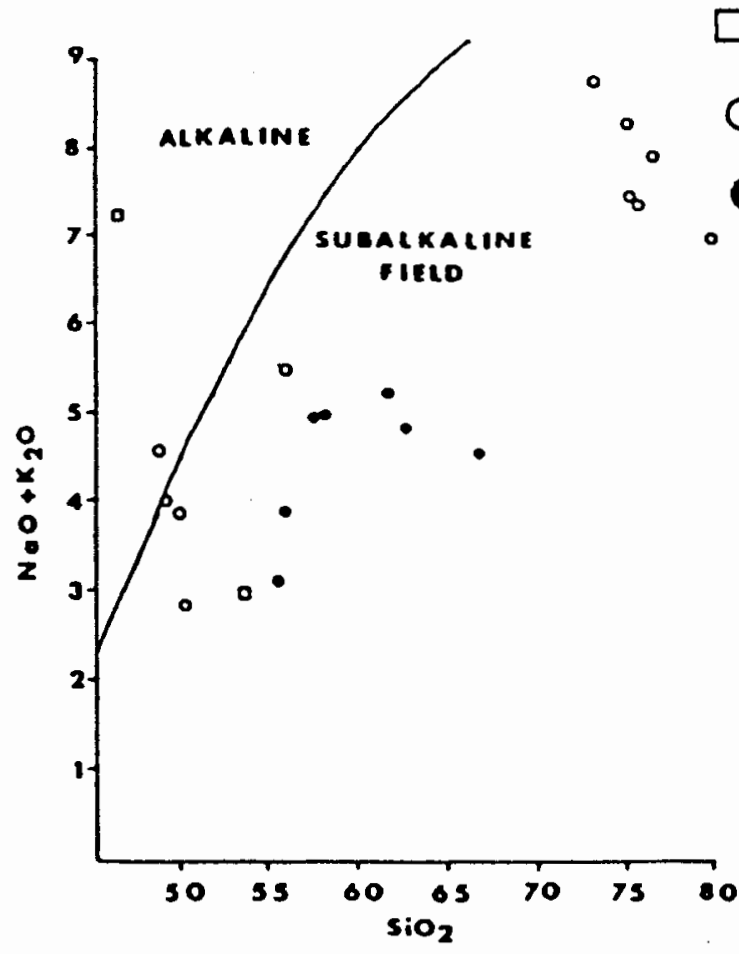

$\square$ John Day Tuff Samples O Upper Clarno Samples Lower clarno. Samples

Figure 10. Total alkalies versus $\mathrm{SiO}_{2}$ plot 

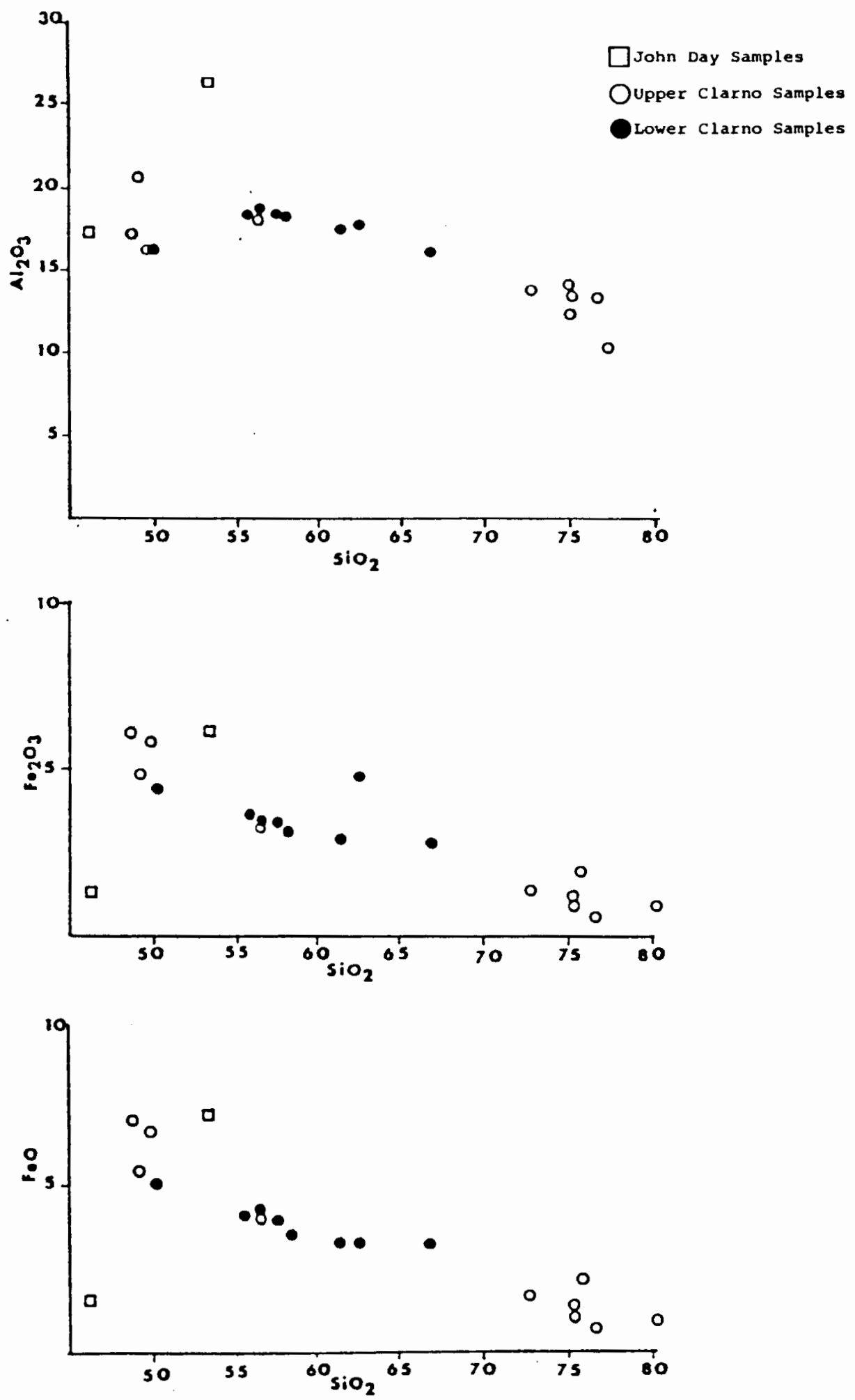

Figure Ila. Harker variation diagrams for Clarno and John Day rocks. 

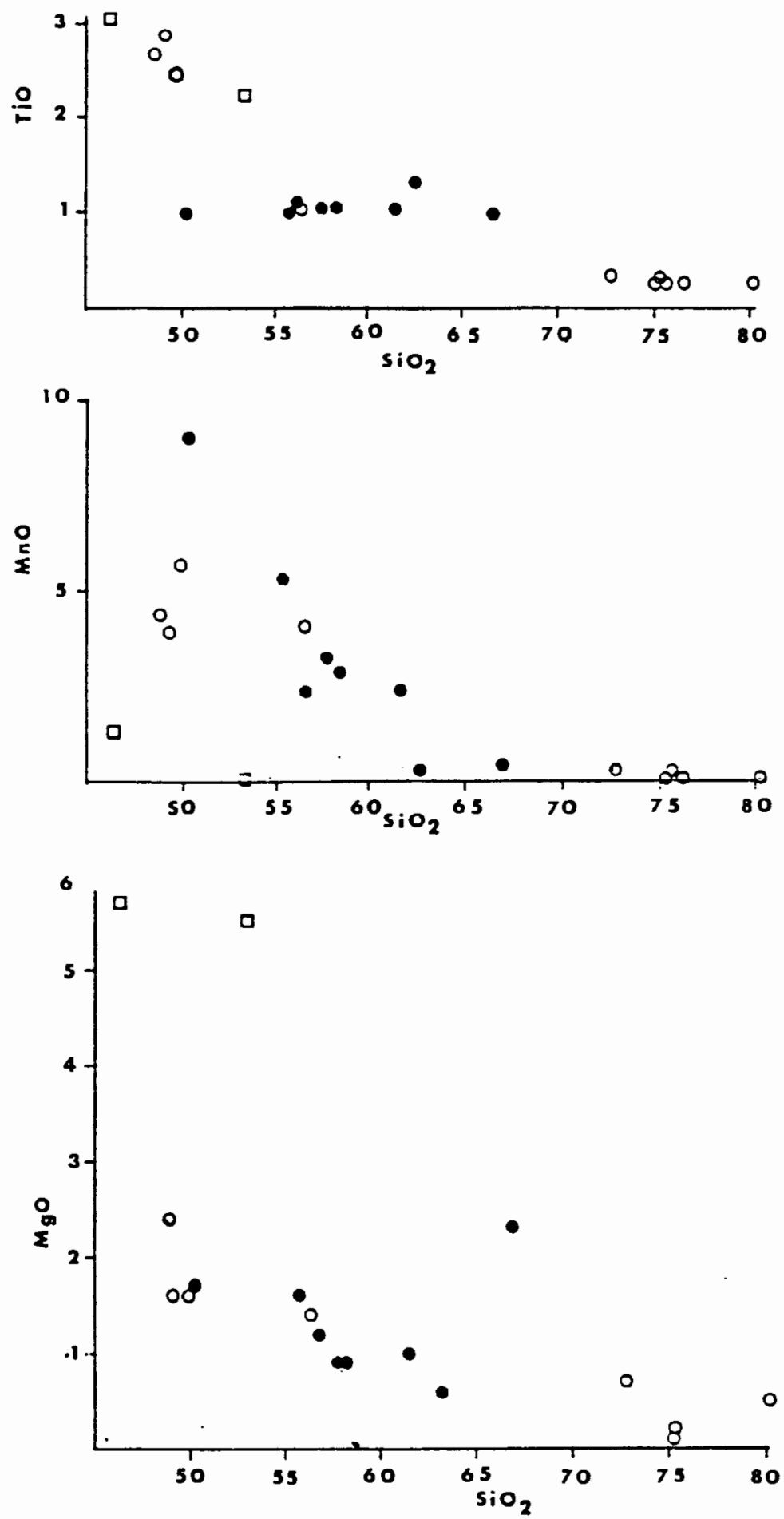

Figure 11b. Harker variation diagrams for Clarno and John Day rocks. 

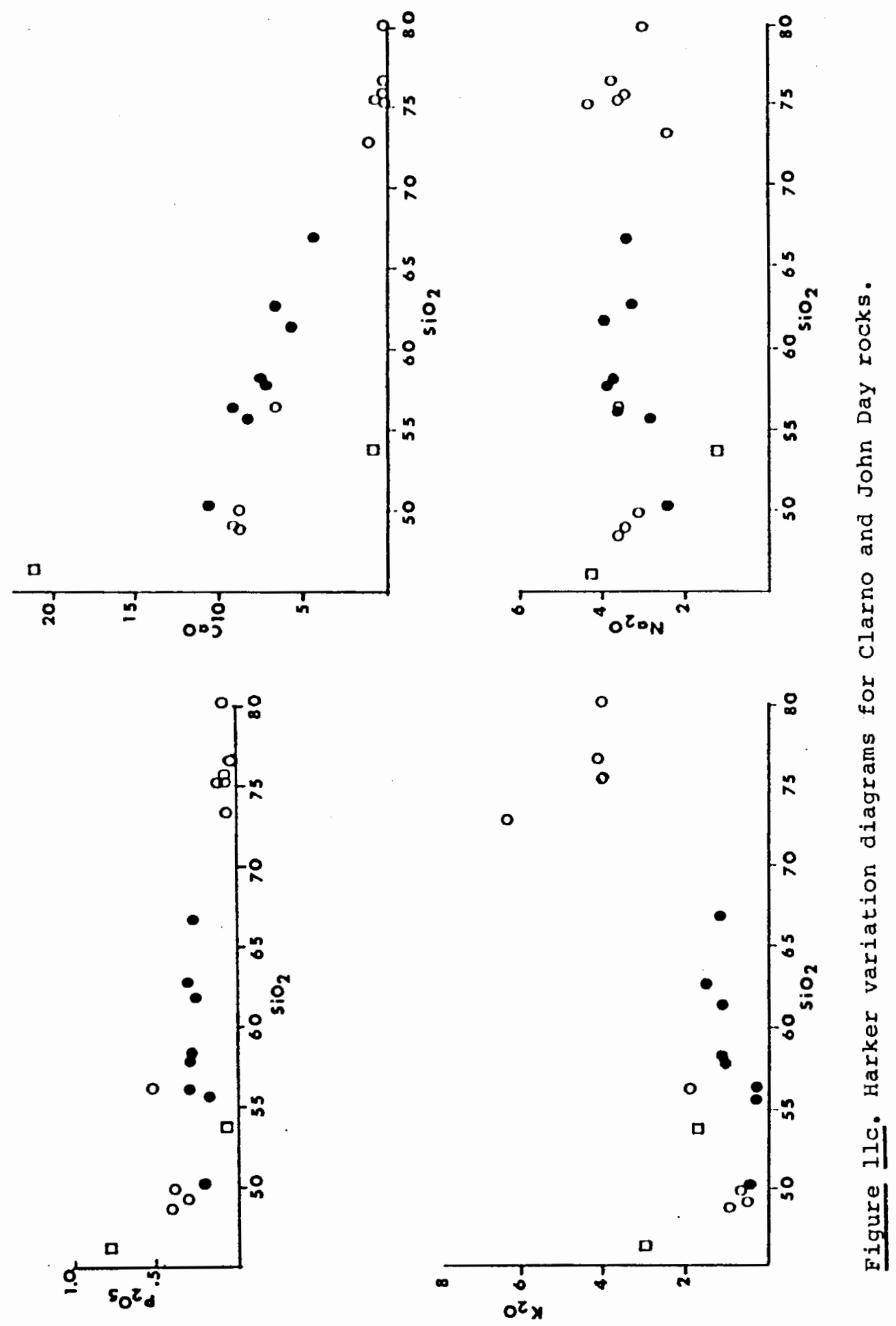
concentrations are generally $>16 \%$ in basalts and andesites. The range of the high alumina field of Irvine and Baragar (1971) is between 16 and $20 \%$ AI 0 .

Other variation diagrams indicate that most rock samples have moderate $\mathrm{K} O$ concentrations as shown by the slope of $\mathrm{K} O \mathrm{vs} \mathrm{SiO}$ (Fig. $11 \mathrm{~b}$ ) and by $\mathrm{K} 0 / \mathrm{Na} \mathrm{O}$ ratios less than 1. The plot of total alkali vs $\operatorname{SiO}_{2}^{2}$ (Fig. 10) indicates that all samples, except the basalts of the upper Clarno, fall within the subalkaline field (Irvine and Baragar, 1971; MacDonald 1968). These upper Clarno basalts, BCB-325, 655, and 84 , stradle the boundary between the alkaline and subalkaline fields. The Harker variation diagrams of all rocks analyzed also indicate a decrease in $\mathrm{FeO}, \mathrm{MgO}$, and $\mathrm{CaO}$ with an increase in the alkali concentration which, in turn, is correlative with increasing silica content (Fig. $11 \mathrm{a} \& \mathrm{~b}$ ). These data, as well as the AFM plot and the afore mentioned Harker variation diagrams, are in accordance with previous work in the petrology and geochemistry of the Clarno Formation (Oles and Enlows, 1971; Novitsky-Evans 1977; Rogers and Novitsky-Evans, 1977a, 1977b) in the area of Mitchell, Oregon.

Although the analyzed samples are within the highalumina calcalkalic series, further scrutiny indicates that samples $B C B-170,263,425,160,588,717$, and 540 , from the lower Clarno Formation, represent rocks of basaltic 
andesite to dacitic composition respectively. Coats (1968) suggested that basic volcanic rocks with phenocrysts of labradorite or bytownite and SiO concentrations between 2 54-58\% should be labled basaltic andesite. Although this classification is not universally accepted, e.g. Irvine and Baragar (1971), it has been chosen as an appropriate division in this study. Samples, BCB-63, 112, 45, 385, and 143 are rhyolites and tuffs and samples $B C B-325,655$, and 84 are basalts from the upper sequence of the Clarno Formation.

Subgroups formed by samples from the lower and upper sequences of the Clarno Formation can be defined by using Harker variation diagrams (Fig. 11a,b,c). Sample BCB-133 has lower Si0 concentration than other samples from the lower Clarno Formation. The SiO concentration is closer to that found in the basalts of the upper Clarno. This sample is from an isolated outcrop surrounded by the paleosol formed on the lower Clarno which, from field relations, would place it within the upper Clarno. However the variation diagrams of $\mathrm{Na} \mathrm{O}, \mathrm{MgO}$ and $\mathrm{TiO}$ (Fig. 11b,c) indicate dissimilarities with the basalts of the upper Clarno. The plot of TiO clearly indicates that BCB-133 does not belong with the basalts of the upper Clarno and thus it is assigned to the lower sequence of the Clarno Formation. Barker (1983) indicates that TiO vs SiO is the single best discriminant for distinguishing "oceanic" 
basalt from volcanic arc basalts. The "oceanic" basalt commonly has TiO concentrations exceeding 1.75 wt\%, whereas circumoceanic basalts have less. The low TiO concentration of this sample indicates that it belongs in the field of circumoceanic basalt which is also the field of the basaltic andesites of the lower Clarno Formation.

The plots of $\mathrm{FeO}, \mathrm{CaO}$, and $\mathrm{MnO}$ of upper Clarno rocks continue the trends defined by rocks of the lower sequence of the Clarno Formation. However, some diagrams indicate a pronounced divergence from trends formed by the lower Clarno rocks. This is especially true for the Harker variation diagrams of $\mathrm{TiO}_{2}, \mathrm{Al}_{2} \mathrm{O}_{3}$, and $\mathrm{MgO}$ (Fig. 1la, C) and to a lesser extent for the plots of $\mathrm{K} O$ and $\mathrm{P} \mathrm{O}^{0}$ (Fig. $11 \mathrm{~b}$ ). The felsic and mafic rocks of the upper sequence of the Clarno Formation form separate fields in these diagrams. The felsic rocks are depleted in $\mathrm{TiO}_{2}, \mathrm{~A}_{2} \mathrm{O}_{3}$, and $\mathrm{MgO}$ relative to the lower Clarno rocks. The basalts have higher concentrations of $\mathrm{TiO}$ and lower $\mathrm{Al}_{2} \mathrm{O}_{3}$ and $\mathrm{MgO}$ concentrations, and stradle the alkaline/subalkaline boundary relative to the lower Clarno rocks. The variation diagram of $\mathrm{P}_{2} \mathrm{O}_{5}$ indicates that the felsic rocks are depleted and the basalts are slightly enriched relative to rocks of the lower Clarno. The felsic rocks of the upper Clarno are enriched relative to other samples in $\mathrm{K} 0$. Sample BCB-195 was collected from the lower slope of Rodman Rim (Plate 2) and was assumed to represent besial.t. 
from the High Lava Plains province. However, when compared to major oxides from other analyses of these basalts (Berri, 1982; Hart and others, 1984; Johnson, 1984; in appendix A), the sample is found to be rich in silica and to lie outside of the fields generated in Harker variation diagrams for these basalts. The ratios of $\mathrm{P} O, K 0$, and TiO also indicate that the sample is not in the compositional field of the basalts of the High Lava Plains. The sample was then compared to the Prineville chemical type of the Columbia River Basalt Group (Uppuluri, 1974). Again sample BCB-195 appears to be compositionally distinct based on comparison of major oxide concentrations ( appendix A).

Comparing the geochemistry of sample BCB-195 with work by Robinson (1969) on basalt flows in the John Day Formation indicates several major differences. The John Day basalts have lower SiO and $\mathrm{K} O$ concentrations and are enriched in TiO and FeO compared to BCB-195 (appendix A). Several Harker variation diagrams, $\mathrm{Na}_{2} \mathrm{O}, \mathrm{TiO}_{2}, \mathrm{Al}_{2} \mathrm{O}_{3}$, and FeO as total iron (Fig. $9 \mathrm{a}, \mathrm{b}, \mathrm{c}$ ), as well as the AFM diagram (Fig. 9) and the total alkali graph (Fig. 10) indicates that this sample is similar to the andesites of the lower Clarno. The concentrations of $\mathrm{P} O$ and $\mathrm{K} O$ ( Fig. $11 c$ ) are enriched compared to the fields formed by the lower Clarno samples. However, the stratigraphic relationships imply that this andesite lies above the rhyolites of the 
upper group of the Clarno. This would be similar to the stratigraphic position of andesites at the Horse Heaven mining area (Waters and others, 1981) that overlay the rhyolites in that area. The petrography of these andesites is also similar. A thin-section of $B C B-195$ shows it to be an augite-bearing intermediate rock with plagioclase phenocrysts. This is similar to the descriptions of the uppermost andesites in the Horse Heaven mining area (Waters and others, 1951). Unfortunately no geochemical analyses are available for rocks from the Horse Heaven mining area. Two samples, $B C B-300$ and 342 , represent two tuff units of the John Day Formation present in the study area. BCB300 is from the welded upper unit and $B C B-342$ is from the redish claystone unit. Sample $B C B-300$ has elevated concentrations of $\mathrm{CaO}$ and $\mathrm{TiO}_{2}$ relative to other samples. $\mathrm{K} O$ and $\mathrm{MnO}$ are also elevated but only slightly. These 2 concentrations indicate that the sample has probably undergone alteration, which is confirmed in thin section. Calcite is abundant and accounts for the high $\mathrm{CaO}$ concentrations. Sample BCB-342 has strongly elevated A1 0 concentrations and to a lesser degree $\mathrm{MgO}$. $\mathrm{CaO}$ and $\mathrm{Na} \mathrm{O}_{2}^{2}$ concentrations are depleted. This indicates alteration or weathering to soil but not in the same manner as in sample $\mathrm{BCB}-300$.

Work by Garcia (1978) indicates that major element chemical analyses may reflect weathering and alteration. 
As stated in the preceeding chapter, alteration is quite common in this area. Accordingly the concentrations plotted for the major oxides should not be interpreted as those of completely unaltered rocks. However, the concentrations of most samples fall within the fields determined by Novitsky-Evans (1974), Rogers and NovitskyEvans (1977a and b), and Rogers and Ragland (1980). The previous work was with rocks of the lower sequence of the Clarno Formation and the data from this study for the lower sequence rocks generally plots along similar trends. The upper sequence of rocks are more similar petrographically to those described by Waters and others (1951), however, geochemistry is not available for the rocks from the area they studied.

Himes (pers. comm. 1983) analyzed eight relatively unaltered samples from the study area for trace elements by INAA. Three basalts, two basaltic andesites and three andesites from the upper and lower Clarno Formation were analyzed. The REE concentrations have been normalized against chondrite concentrations (Nakamura, 1974) and plotted in figure 12. This graph is similar to those of rocks in a forearc setting (Culley and Graf, 1984). However, Ce has been depleted relative to the other REE. A second analysis of $B C B-170$ by the author indicated no Ce depletion. Interference from Yb probably accounts for this depletion. 
Geochemistry of the basalts of the High Lava Plains

Two grab samples of the basalts that form Rodman Rim and A1kali Flat, BCB-1059 and 1053 respectively, were analyzed by INAA. The chondrite normalized graph of these basalts is shown on figure 12. $B C B-1059$, which is from the older flow that underlies Rodman Rim, has a lower abundance of REE overall which may indicate a less fractionated magma. Graphs for the two samples are similar in shape with the exception of a Ce depletion in sample BCB-1059. The ratios of the REE (Table II) are also similar. REE plots for two basalt samples from the upper Clarno and five samples of basalts of the High Lava Plains that surround Glass Buttes in Lake County, Oregon, (Berri, 1982; Johnson, 1984) are included (Fig. 12). Comparisons of the REE data from both Glass Buttes and Bear Creek Butte indicate a relatively broad field of REE concentrations. The field is broad enough to also include the two basalt samples of the Upper Clarno from Bear Creek Butte.

Various other trace elements are 1 isted in appendix C. The basalts of the High Lava Plains are generally higher in Cr than basalts of the Clarno Formation except for the Glass Butte sample 2 which has $\mathrm{Cr}$ concentrations significantly lower than the other High Lava Plains Basalt samples. Sample 2 represents a porphyritic basalt from Glass Buttes. This basalt was informally named by Berri (1982) as internal basalt. It represents a basalt that 
TABLE II

\title{
RARE EARTH ELEMENT RATIOS
}

\author{
EU/SM I.A/SM LA/YB EU/SM LA/SM LA/YB
}

\section{PLATNER hINE}

$\begin{array}{lllllllll}1 A & .62 & 1.75 & 3.59 & 1001 & .83 & 1.50 & 3.28 \\ 2 A & .48 & 2.53 & 6.12 & 1002 & .69 & 1.83 & 3.59 \\ 3 A & .66 & 1.91 & 3.97 & 1003 & .73 & 1.73 & 3.11 \\ 4 A & .61 & 1.78 & 3.77 & 1004 & .82 & 2.39 & 4.10 \\ 5 A & .77 & 3.38 & 5.58 & 1005 & .78 & 1.67 & 3.23 \\ 6 A & .77 & 1.92 & 2.83 & 1006 & 1.00 & 2.10 & 3.54 \\ 7 A & .72 & 2.10 & & 1006 A & .95 & 2.18 & 4.72 \\ 0 & .78 & 1.46 & 2.73 & 1007 & .71 & 1.70 & 4.01 \\ 1 & .81 & 1.45 & 2.82 & 1008 & .67 & 1.60 & 2.25 \\ 2 & .83 & 1.46 & 2.58 & 1041 & .22 & 2.24 & 4.61 \\ 3 & .83 & 1.53 & 2.79 & 1042 & .24 & 2.33 & 5.26 \\ 4 & .64 & 2.25 & 3.77 & 1043 & .64 & 2.07 & 4.35 \\ 5 & .64 & 2.20 & 4.37 & 1044 & .63 & 2.12 & 4.64 \\ 5 R & .71 & 1.75 & 3.27 & 1046 & .24 & 2.19 & 4.80 \\ 6 & .81 & 1.37 & 3.11 & & & & \\ 7 & .71 & 2.52 & 4.08 & C A-M & .60 & 2.39 & 3.18 \\ 8 & & & 2.84 & & & & \\ 9 & .68 & 2.20 & 3.98 & 351 & .58 & 2.31 & 5.14 \\ 10 & .49 & 1.32 & 3.34 & 655 & .81 & 1.46 & 2.88\end{array}$

$\begin{array}{llll}\text { 1B } & .68 & 1.38 & 2.83 \\ \text { 2B } & .48 & 2.31 & 4.65 \\ \text { 3B } & .77 & 1.79 & 4.29 \\ \text { 4B } & .66 & 2.29 & 5.09 \\ \text { 5B } & .23 & 3.00 & 5.36 \\ \text { 6B } & .51 & 2.38 & 5.01 \\ \text { 7B } & .53 & 2.46 & 5.05\end{array}$

ORONOGO MINE

$\begin{array}{llll}1010 & .74 & 2.04 & 5.61 \\ 1011 & .76 & 2.36 & 6.50 \\ 1012 & .75 & 2.30 & 7.30 \\ 1013 & .74 & 2.07 & 5.31 \\ 1014 & .75 & 2.37 & 7.58 \\ 1015 & .74 & 2.07 & 6.35 \\ 1016 & .66 & 1.67 & 5.54 \\ 1017 & .80 & 1.80 & 6.12 \\ 1018 & .72 & 1.75 & 6.08 \\ 170 & .87 & 1.61 & 3.47\end{array}$

ADMUNSEN CLAIM,

$\begin{array}{lrrr}\text { SHAFT } & .65 & 1.93 & 5.91 \\ \text { ADIT } & .69 & 1.69 & 3.47 \\ 1100 A & .75 & 1.38 & 2.32 \\ 1100 B & 1.16 & 1.96 & \\ 1100 C & .87 & 1.56 & 2.80 \\ 1100 D & .88 & 2.35 & 4.46 \\ 1108 & .79 & 1.34 & 3.55 \\ 1108 A & .74 & 2.27 & 5.90 \\ 1109 & .74 & 1.14 & 2.24 \\ 1109 A & .85 & 1.30 & 2.24\end{array}$

RHYOLITE BUTTES

JOHN DAY TUFFS

$\begin{array}{llll}631 \mathrm{~A} & .53 & 1.75 & 3.70 \\ 631 \mathrm{~B} & .5 ! & 1.84 & 5.44 \\ 631 \mathrm{C} & .41 & 1.71 & 1.75 \\ 631 \mathrm{D} & .50 & 1.74 & 3.75 \\ 1150 & .41 & 1.97 & 3.87 \\ 112 & .28 & 2.03 & 6.95 \\ 128 \mathrm{~B} & .44 & 1.89 & 3.11 \\ 129 & .40 & 1.85 & 4.04 \\ 63 & .47 & 1.95 & 3.29\end{array}$

$\begin{array}{llll}190 & .29 & 1.98 & 3.40 \\ 191 & .27 & 2.01 & 4.02 \\ 193 & .28 & 1.22 & 2.89 \\ 194 & .26 & 2.04 & 3.88 \\ 194 \mathrm{~B} & .26 & 2.10 & 4.11 \\ 196 \mathrm{~B} & .31 & 1.31 & 2.94\end{array}$




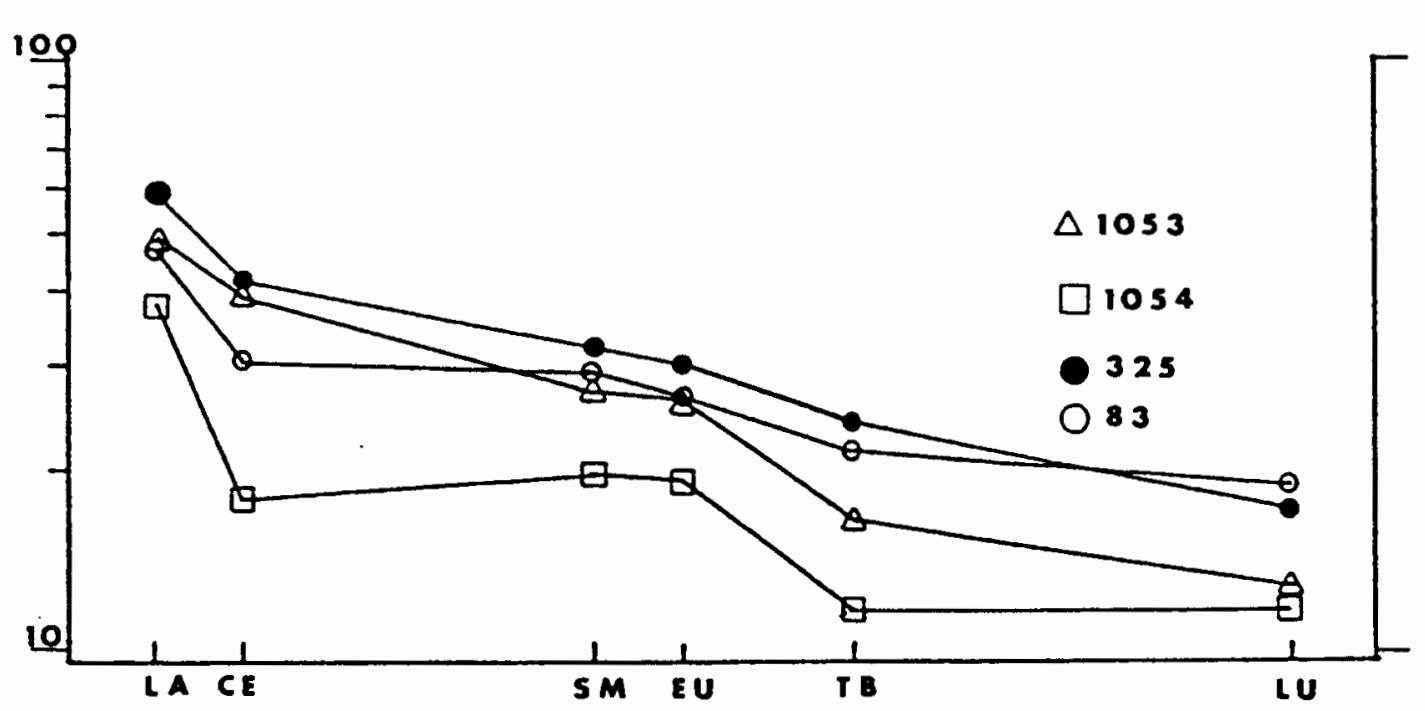

REE graph of samples of basalts

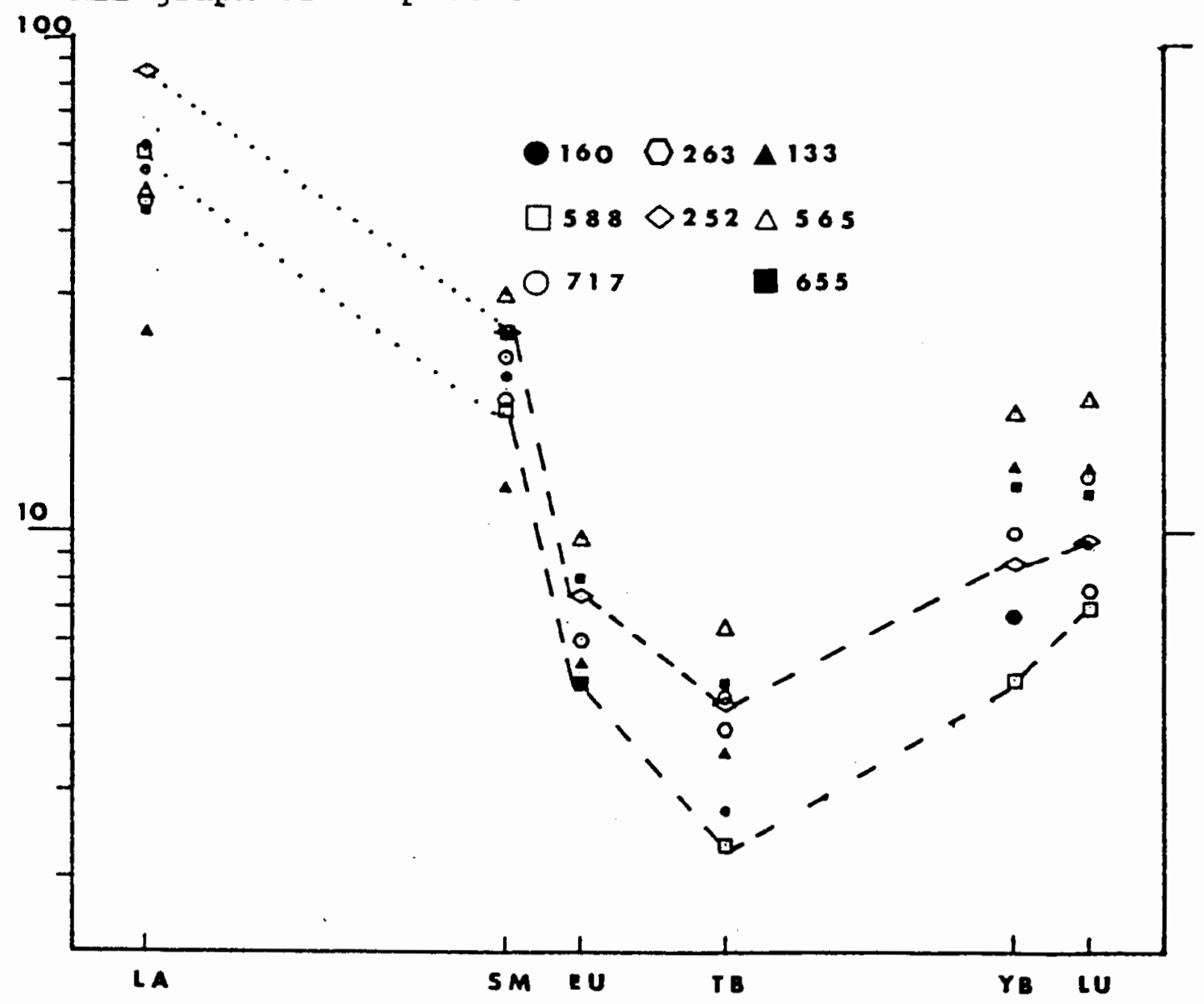

REE graph of unaltered rock.

Figure 12. REE graphs of basalt and unaltered rock. 
crops out within the Glass Butte rhyolite complex rather than the surrounding plains. Thorium concentrations are lower in High Lava Plains Basalts than basalts of the upper Clarno.

Although the broad field defined by REE concentrations formed by these seven samples of basalts from the High Lava Plains overlaps the plots of upper Clarno basalts, other concentrations of trace elements indicate potential for differentiating the flows of the High Lava Plains. Chromium is enriched in the basalts of the High Lava Plains relative to other analyzed basalts in the area. The basalts that form the rim rock at Bear Creek Butte are depleted in Th relative to basalts of the upper Clarno and Prineville chemical type of the Columbia River Basalt Group. This lower concentration is also noted in the basa1ts from Glass Butte.

Geochemistry of the cinnabar prospects

Compilation of Humphris' (1984) work and that of others indicate that the chemistry of REE in hydrothermal systems is a complex interaction between primary and secondary processes. Evidence exists for both mobility and immobility of the REE in low temperature alteration. However, with caution, REE patterns can be used to classify rocks and interpret petrogenetic processes. In 1 ight of this, the chondrite normalized (Nakamura, 1974) plots and ratios of REE from the various traverses from the altered 
areas provide interesting data, particularly that from the Platner mine area. The data from the $B$ and 1040 traverses (Table II) indicate REE concentrations that are 2 to 3 times greater than those across the core of the Platner mine (Table II). This could be explained by dilution effects due to addition of silica to the area characterized by lower REE values. This is supported by the ratios of Eu/Sm, La/Sm, and La/Yb which measure the relative fractionation of the REE (Frey, 1980). These ratios are quite similar for samples that are known to be tuffs, T-5A, T-5 and al1 samples from traverse $B$ except $T-1 B$ (Table II) which is lower Clarno andesite.

The graphs from the more altered area of the Platner mine reflects the negative Ce anomaly found in the "fresh" rock REE plot (Fig. 13a, b). However, this Ce depletion can possibly be explained by weathering or low temperature alteration involving high water/rock ratios. The high water/rock ratio is indicated by silica flooding and large areas of argillization seen at the prospect.

However, this interpretation becomes less reliable when Hf vs Ta (Fig. 14) is plotted. Hf and Ta are two of the least mobile trace elements and thus their ratios are more likely to reflect original concentrations. This graph indicates the presence of two separate fields, one formed by samples from the core of the Platner mine and the other, with more elevated concentrations, by the samples from 
traverse B. Thus although a case for silica flooding in the central area of the Platner mine causing the depletion of REE by dilution as well as the Ce depletion can be made, the Hf vs Ta graph tends to indicate that the rocks that form the ridge south of the Platner mine are more felsic than those at the core of the Platner mine. This implies two distinct tuffaceous units at the Platner mine, not one as stated by Brooks (1963). However, both of the tuffs and the basalts at the Platner mine belong to the upper sequence of the Clarno Formation.

At the Oronogo mine the REE patterns (Fig. 15) are similar to that of sample $B C B-170$, a relatively unaltered sample of basaltic andesite. This sample, as well as the host rocks at the Oronogo mine, represent rocks of the lower sequence of the Clarno Formation. All the samples from the mine have elevated REE concentrations relative to $B C B-170$. This may be due to a loss of mass. Also there is no negative Ce anomaly in the altered rocks in this area. Although this is contrary to the REE pattern for most mafic to intermediate rocks in this area, the Ce anomaly is not present in sample BCB-170 either.

The REE plots of samples from the Admunsen claim indicate that several rock types are present (Fig. 12). Samples SM-S, BCB-1108A, and possibly BCB-1108 have similar REE ratio (Table II) to the felsic tuff south of the Platner mine. However, the concentrations of the REE are depleted 

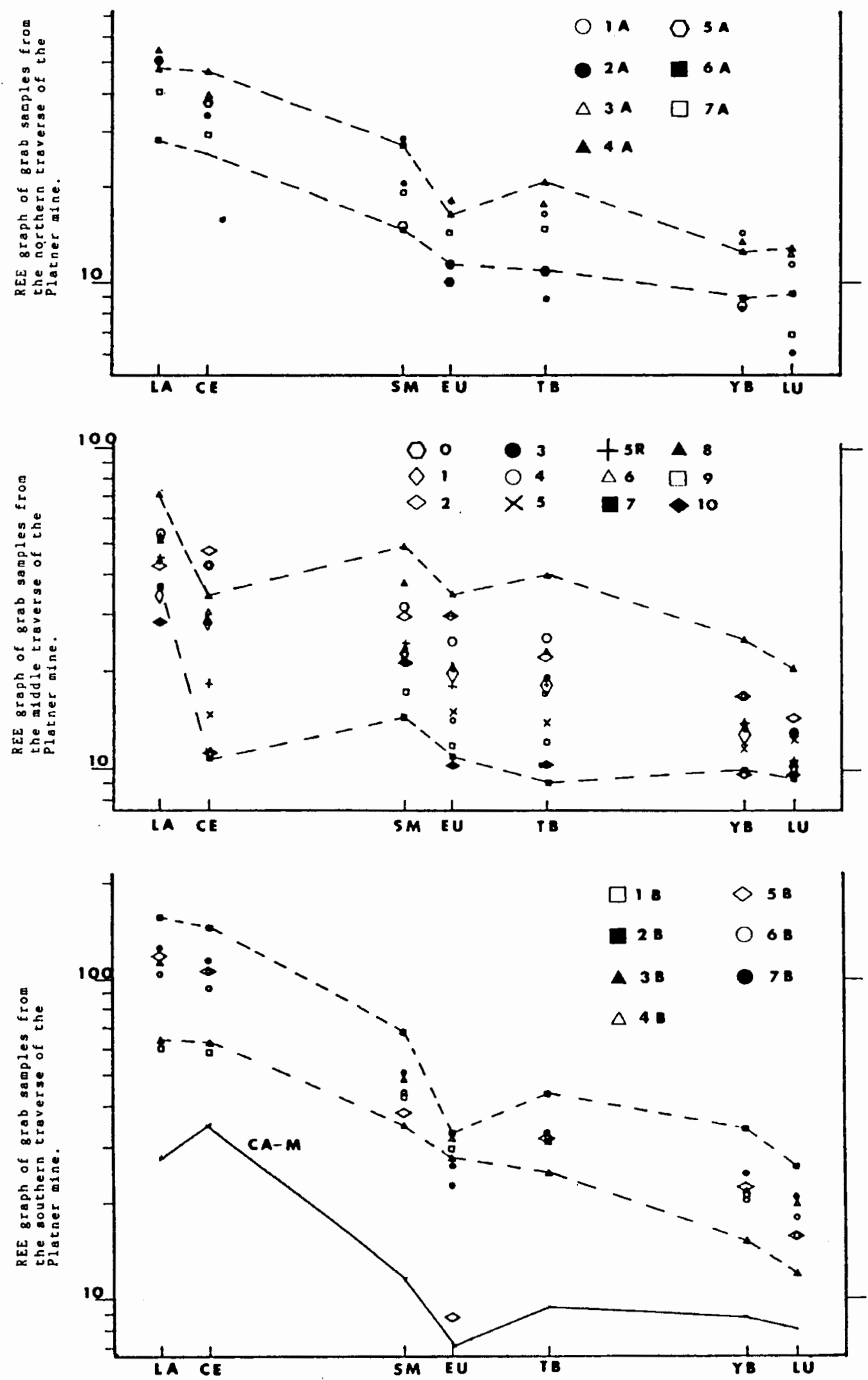

Figure 13a. REE graph of Platner mine samples. 


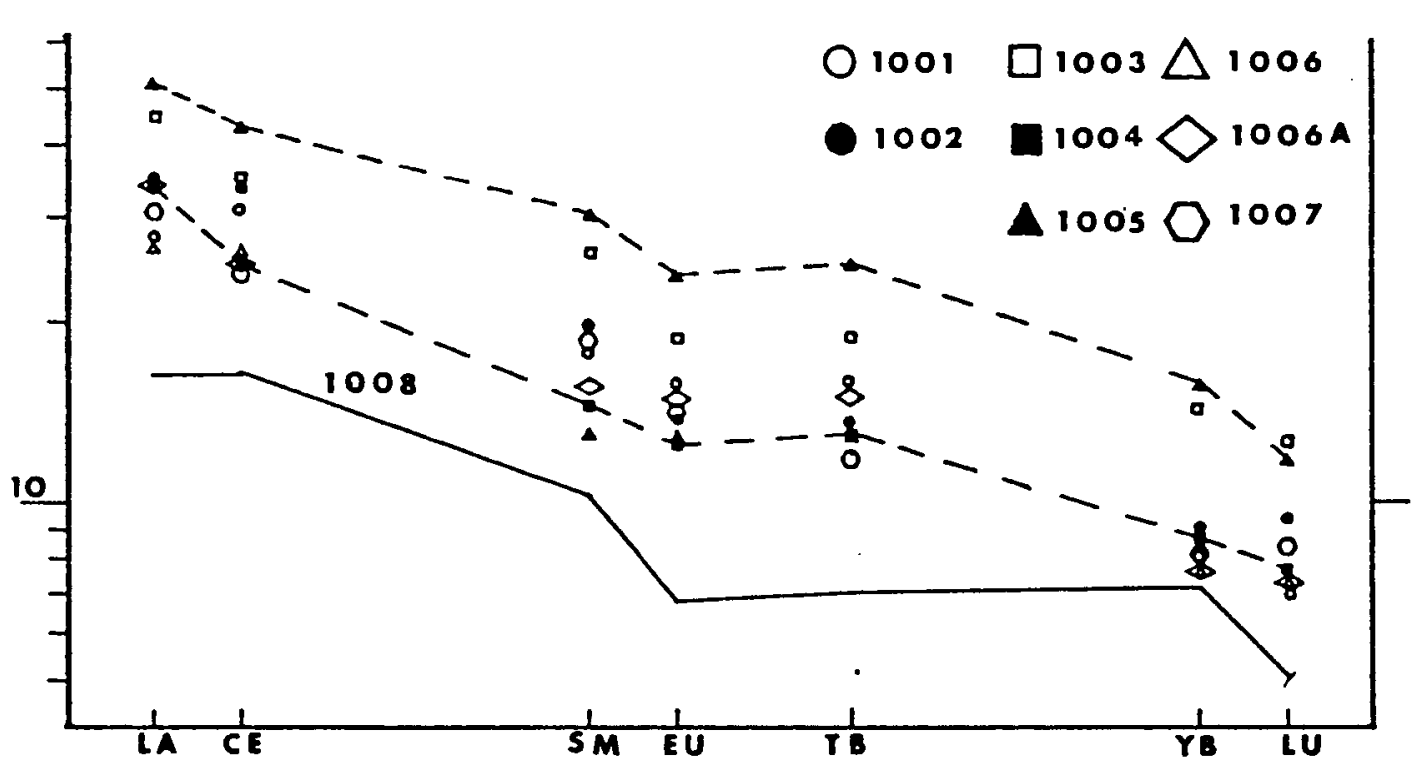

57

REE graph of samples from the northern traverse parallel to the controlling structure.

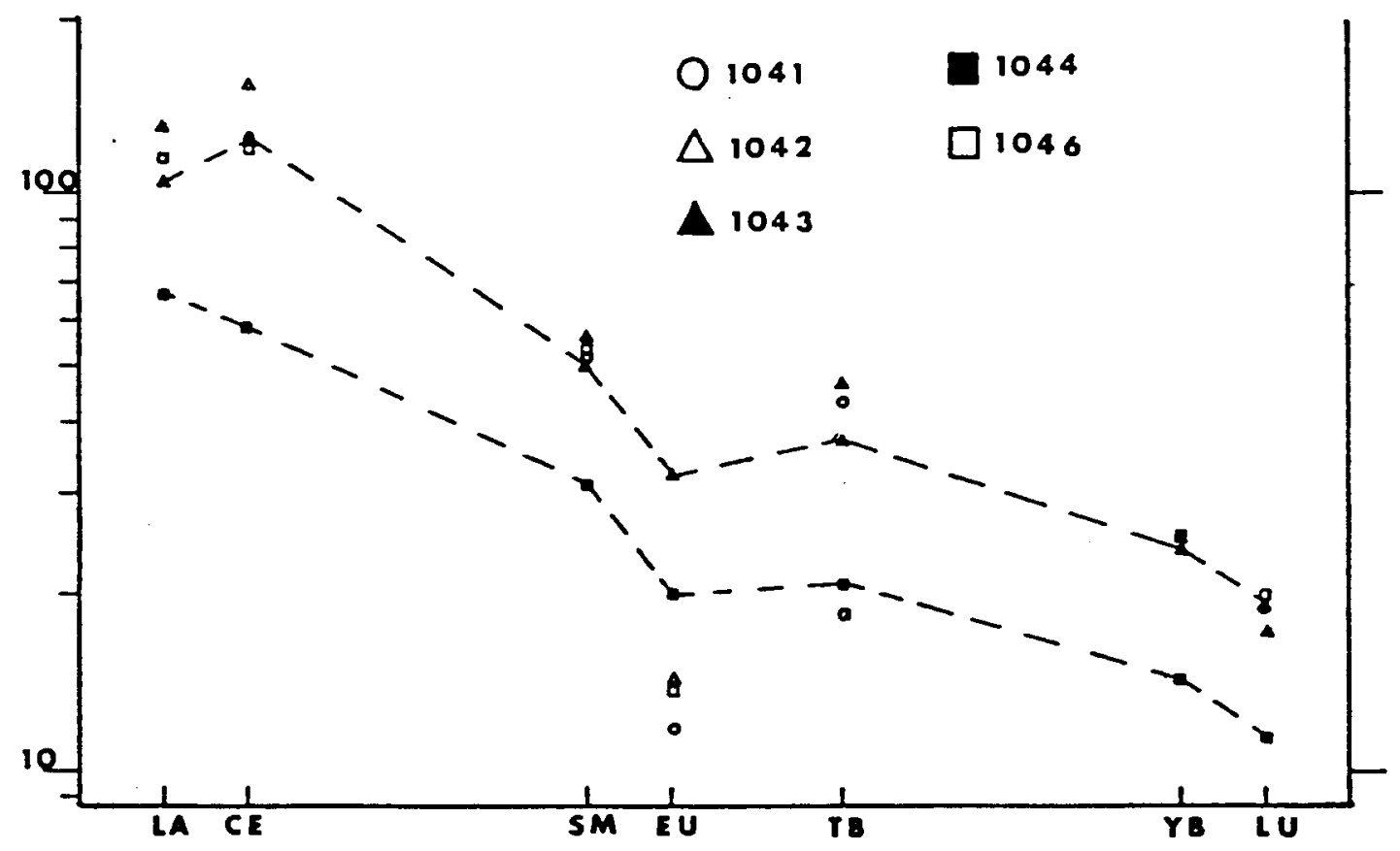

REE graph of bulk samples from a scuthern traverse parallel to the controlling structure.

Figure 13b. REE graphs of samples from the Platner mine. 


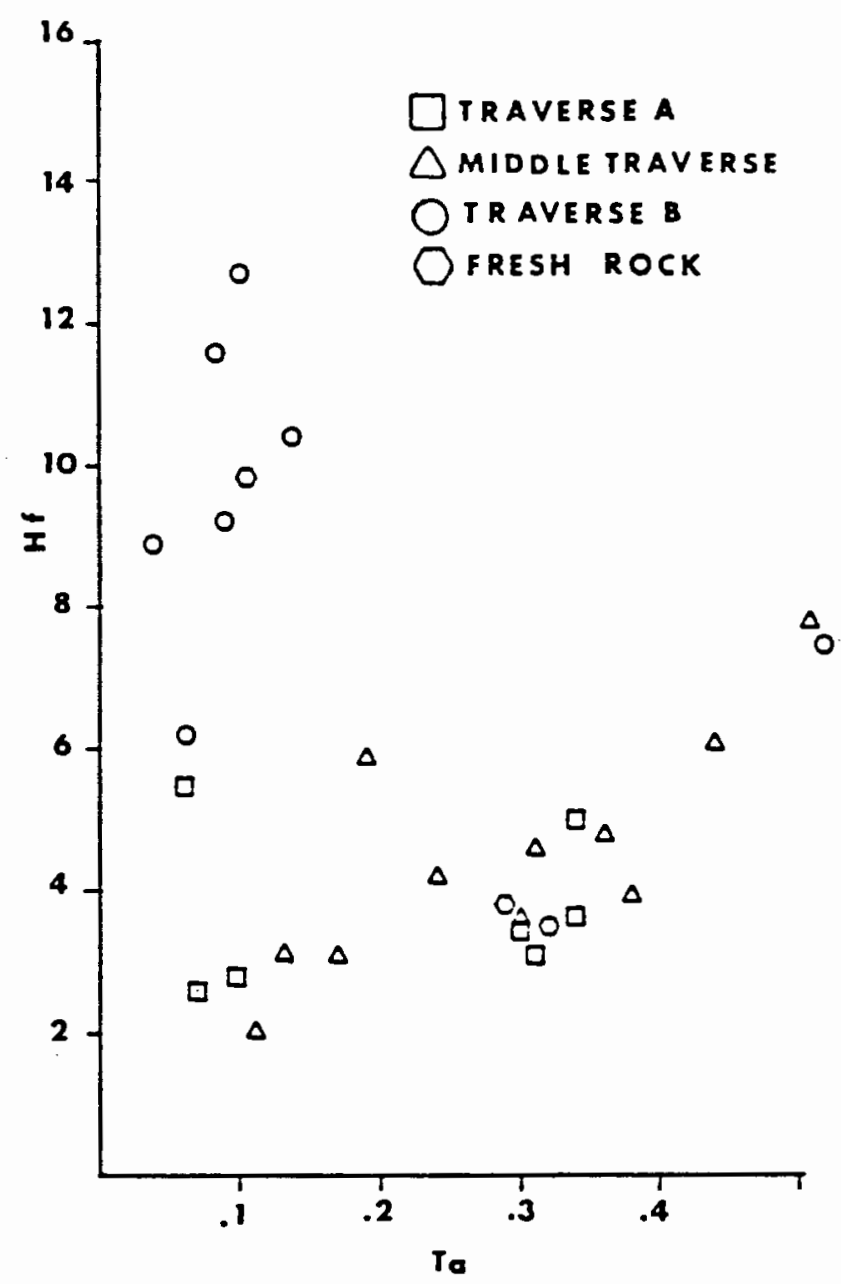

Figure 14. Hf vs Ta 


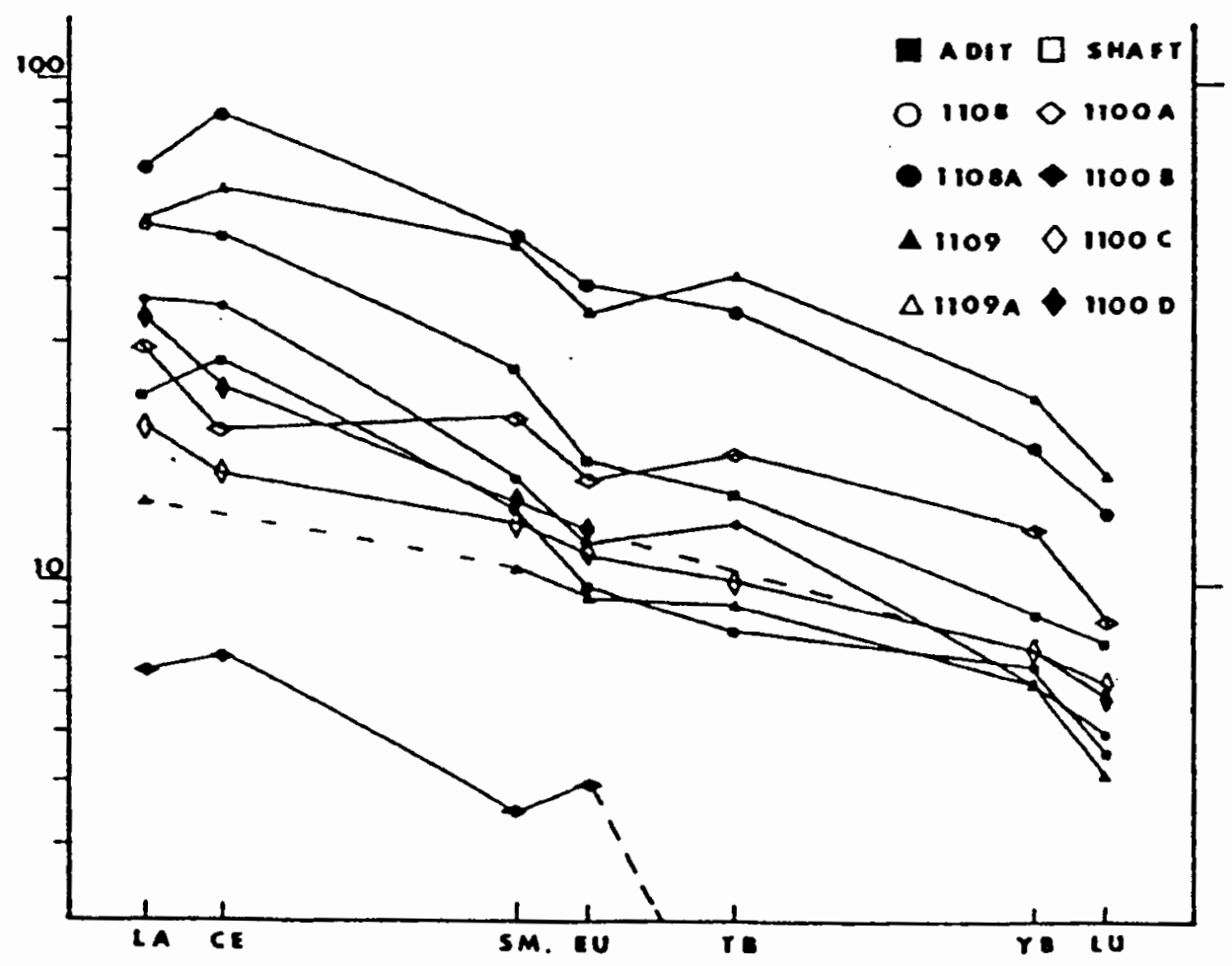

REE graph of samples from the Admunsen claim.

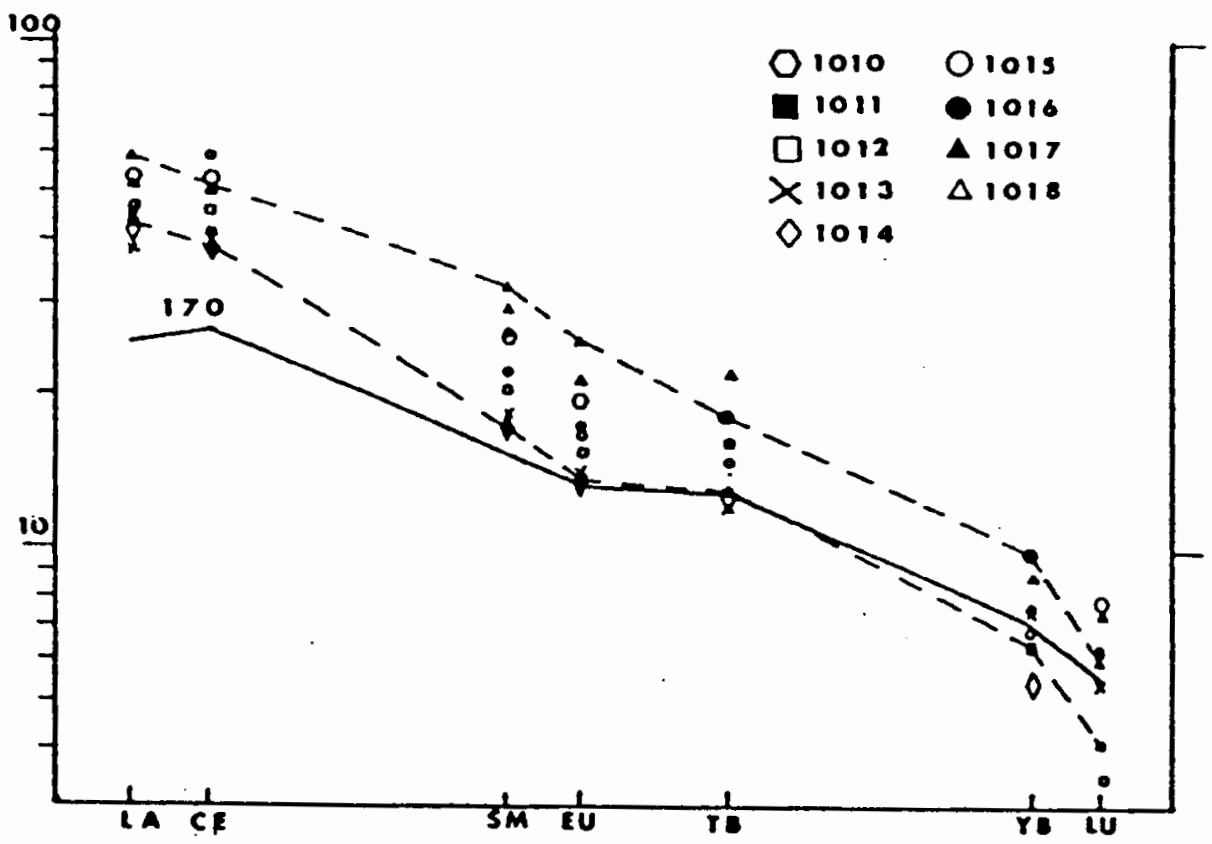

REE graph of samples from the Oronogo mine.

Figure 15. REE graphs of samples from the Admunsen claim and the oronogo mine. 
in comparison to the tuff south of the Platner mine. This depletion can problably be attributed to a diluting effect due to the addition of silica to the rocks at the Admunsen c 1 a im.

The REE patterns allow correlation between areas of alteration at the Platner mine and Admunsen claim. The samples $T-8$, and $T-6 A$ (Fig. 13a) from the Platner mine and 1109 and $1109 \mathrm{~A}$ (Fig. 15) from the Admunsen claim are from mafic intrusions in these areas. The chondrite normalized REE patterns are similar and the La/Sm and La/Yb ratios (Table II) cluster closely together. Combining this information with petrographic information, a similarity in original composition is suggested among the basaltic intrusions found in both areas.

Mercury, arsenic and antimony are accepted pathfinder elements in geochemical exploration for precious metal deposits (Boyle and Jonasson, 1973; Boyle, 1974; Levinson, 1980). Mercury is highly volatile and is common in geothermal and epithermal systems (White, 1967; White, 1983; White and others, 1971). The concentrations of these elements have been listed in Table III. This table indicates that the Platner mine and vicinity is the area with the greatest concentration of $\mathrm{As}, \mathrm{Sb}$, and $\mathrm{Hg}$. Arsenic and $\mathrm{Sb}$ concentrations are expressed in ppm; mercury concentrations have been internally normalized i.e., samples containing $\mathrm{Hg}$ have been compared against a common 
sample containing $\mathrm{Hg}$ but no concentration is known for the sample. Samples $B C B-351$ and 655 represent a relatively unaltered 1ithic tuff and basalt of the upper sequence of the Clarno Formation respectively and are the major 1ithologies at the Platner Mine. Sample BCB-170, a lower Clarno basaltic andesite, provides the background concentration of elements for samples from the Oronogo Mine. Analysis indicates that background concentrations of As, $\mathrm{Sb}, \mathrm{Hg}$, and $\mathrm{U}$ are below detection limits for the basalt and the basaltic andesite.

Within the hydrothermally altered areas the concentrations of Hg varies greatly. The Hg concentrations for individual samples are greatest in the southern portion of the Platner mine area, peaking at 3 times above the norm. However, more samples contain Hg in the area of traverse A.

Traverse $A$ is also the site of the greatest Sb anomaly. Across traverse A, Sb averages 48 ppm and has a highest concentration of 102 ppm. Sb concentrations average 44 ppm, 27 ppm, and 13.3 ppm for the Platner mine, Admunsen claim, and Oronogo mine respectively.

Arsenic distribution is irregular. However, the greatest concentrations of As are found at the Platner mine. Peak concentrations of 45 ppm, 36 ppm, and 31 ppm are found on the three traverses across the fault. These concentrations, when compared to average local 


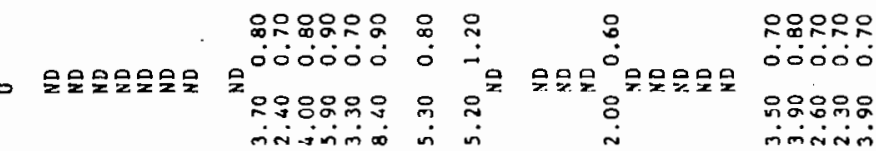

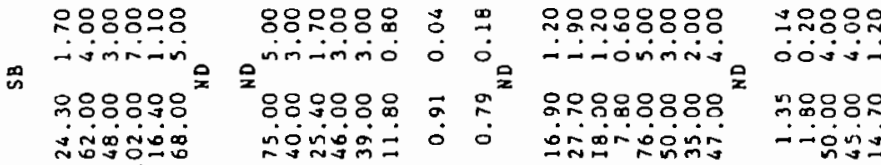

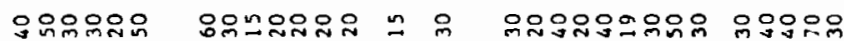

2

000000 0000000 0 o 00000000 00000

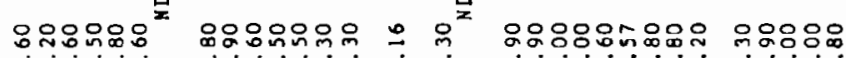

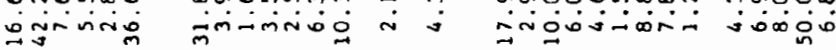

D

呈里

$\infty \frac{1}{a}$

थ

in

4

ن骂

$x \cup$

告

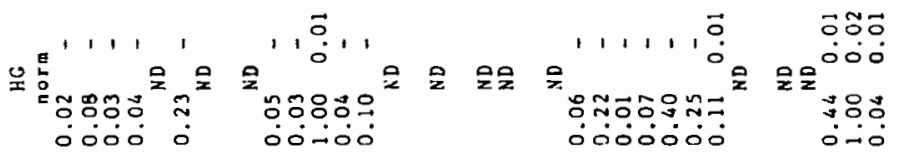

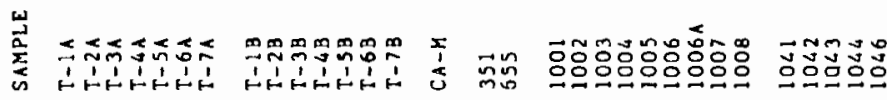

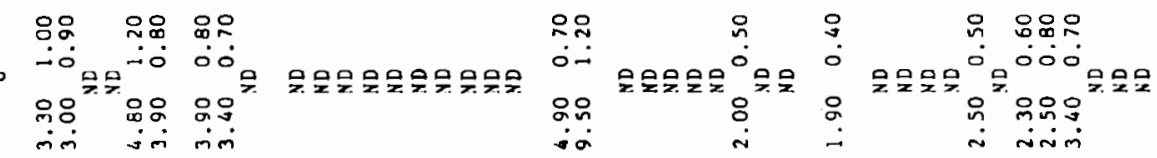

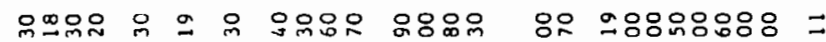

$$
\begin{aligned}
& \text { 禹 }
\end{aligned}
$$

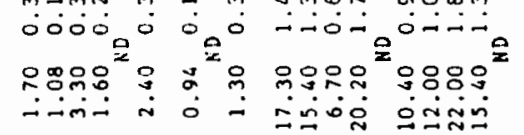

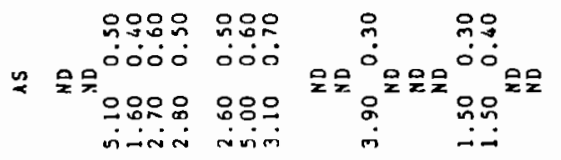

$$
\begin{aligned}
& \text { no ơviomini }
\end{aligned}
$$

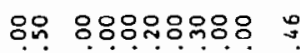

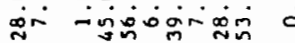

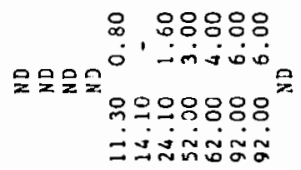

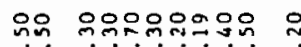

$$
\begin{aligned}
& \text { io Do0000000 }
\end{aligned}
$$

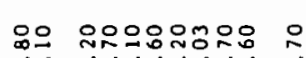

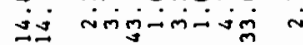

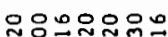

$$
\begin{aligned}
& \text { 0opainojoió } \\
& \text { 으영용요 }
\end{aligned}
$$

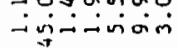

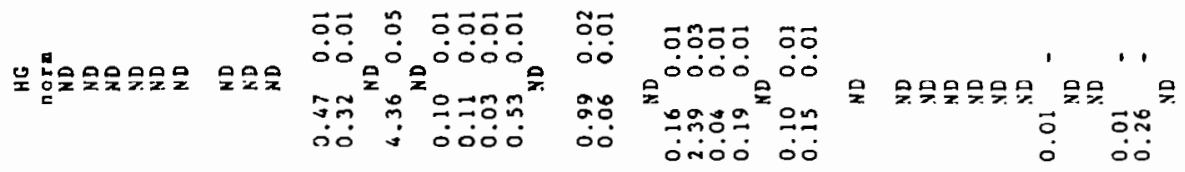

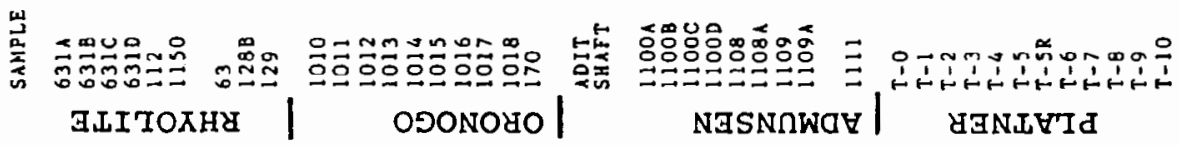


concentrations at the Platner mine, $12 \mathrm{ppm}$, the Admunsen claim, $12 \mathrm{ppm}$, and the Oronogo mine, $3.9 \mathrm{ppm}$, indicate the anomalies are at least 3 times the local average at the Platner mine and that the anomaly is clearly strongest in this area.

An overview of the distribution of these elements indicates a pattern. The three elements show the greatest enrichment in the area of the Platner mine. Within the alteration halo surrounding the Platner mine another pattern is evident. Arsenic and Sb distribution along the controlling structures in the area shows an increase in concentration toward the Platner mine. South of the Platner mine the traverse along the fault shows an enrichment in Sb from $1 \mathrm{ppm}$ to $50 \mathrm{ppm}$, south to north (Table III). Arsenic concentrations also demonstrate this increase, ranging from $4 \mathrm{ppm}$ in the southern end of the traverse to $50 \mathrm{ppm}$ at sample 1046. Antimony concentrations along the northern traverse also show an increase toward the Platner mine though it is not as pronounced as south of the mine. These concentrations range from 169 ppm to 50 ppm. Arsenic concentrations are irregularly distributed in this area and do not demonstrate an increase toward the Platner mine. However, the average As concentration of 7.4 ppm is less than that at the Platner mine itself. As previously mentioned $\mathrm{As}, \mathrm{Sb}$, and $\mathrm{Hg}$ are proven pathfinders for gold. The collected samples were 
considered to be potentially gold bearing. They were analyzed by instrumental neutron activation analysis and compared against the Au standard EMT-7 from Portland State University. Although the detection limits for gold by INAA are $.05 \mathrm{ppm}$, no samples were found to contain gold.

Geochemistry of the uranium prospects

The uranium prospects are hosted in the John Day tuffs that lap onto the southeast slope of Bear Creek Butte (Plate 1). Five grab samples from four pits and one in which no visable alteration was detected, BCB-190, were analyzed by INAA for trace elements including REEs, U, Sb, As, and Mo. The REE were normalized against chondrite concentrations (Nakumura, 1974) and are plotted in figure 16. This plot shows a LREE enrichment similar to felsic rocks (Humphris, 1984). Most samples' REE concentrations plot close to that of the unaltered sample. Only BCB-193 shows a REE depletion but the Eu/Sm ratio falls within the field defined by the other samples (Table II), indicating a similar trend. The observed depletion is related to dilution of the sample by silica.

The host rocks for the prospects in this area are peraluminous tuffs, as indicated by whole rock analyses. This is somewhat unusual. Most uranium deposits in North America are hosted in peralkaline rocks (Curtis, 1981; Rytuba and Conrad, 1981; WaI lace and Roper, 1981). Instead the area is similar to the Lakeview District (Castor and 


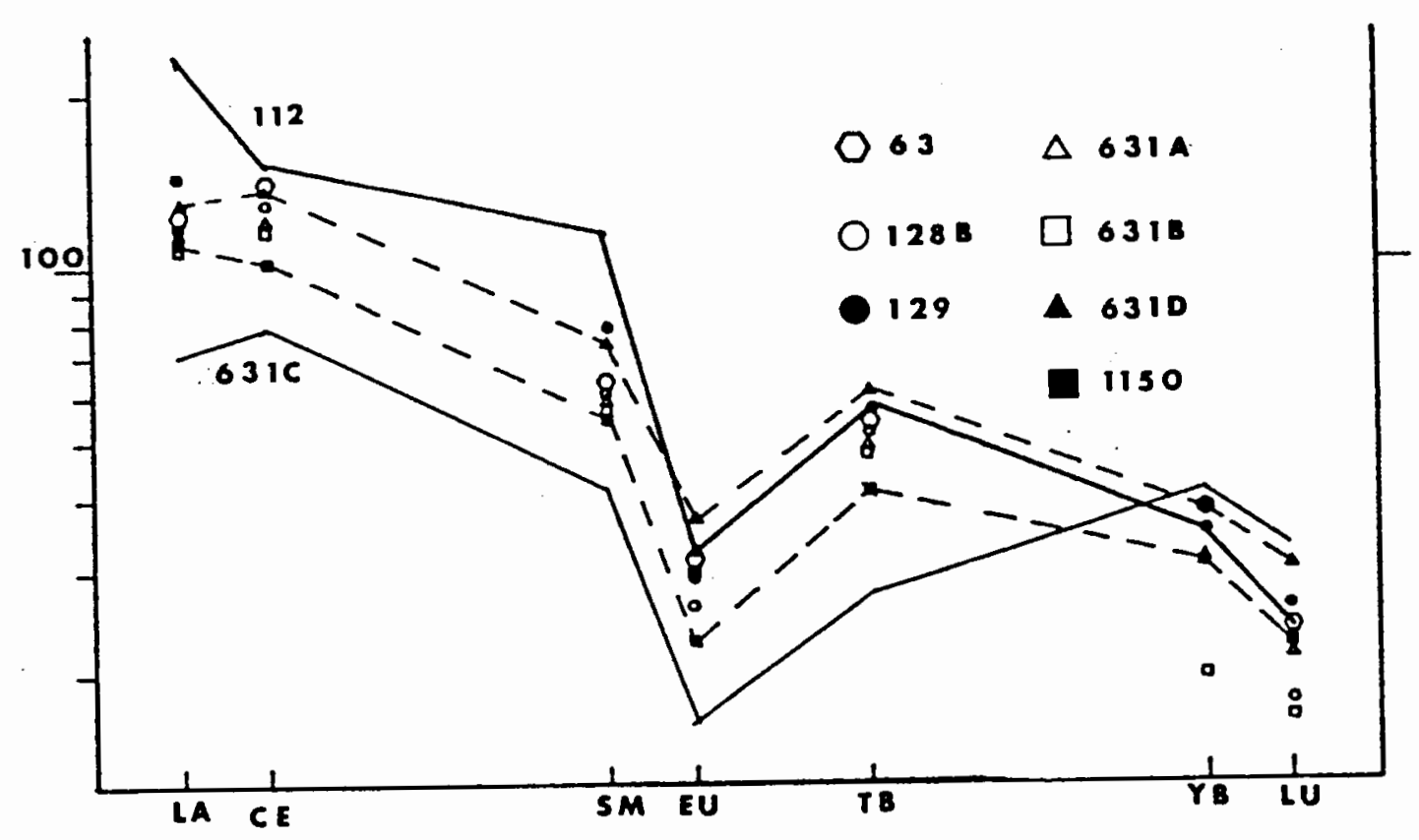

REE graph of samples from fumeroles.

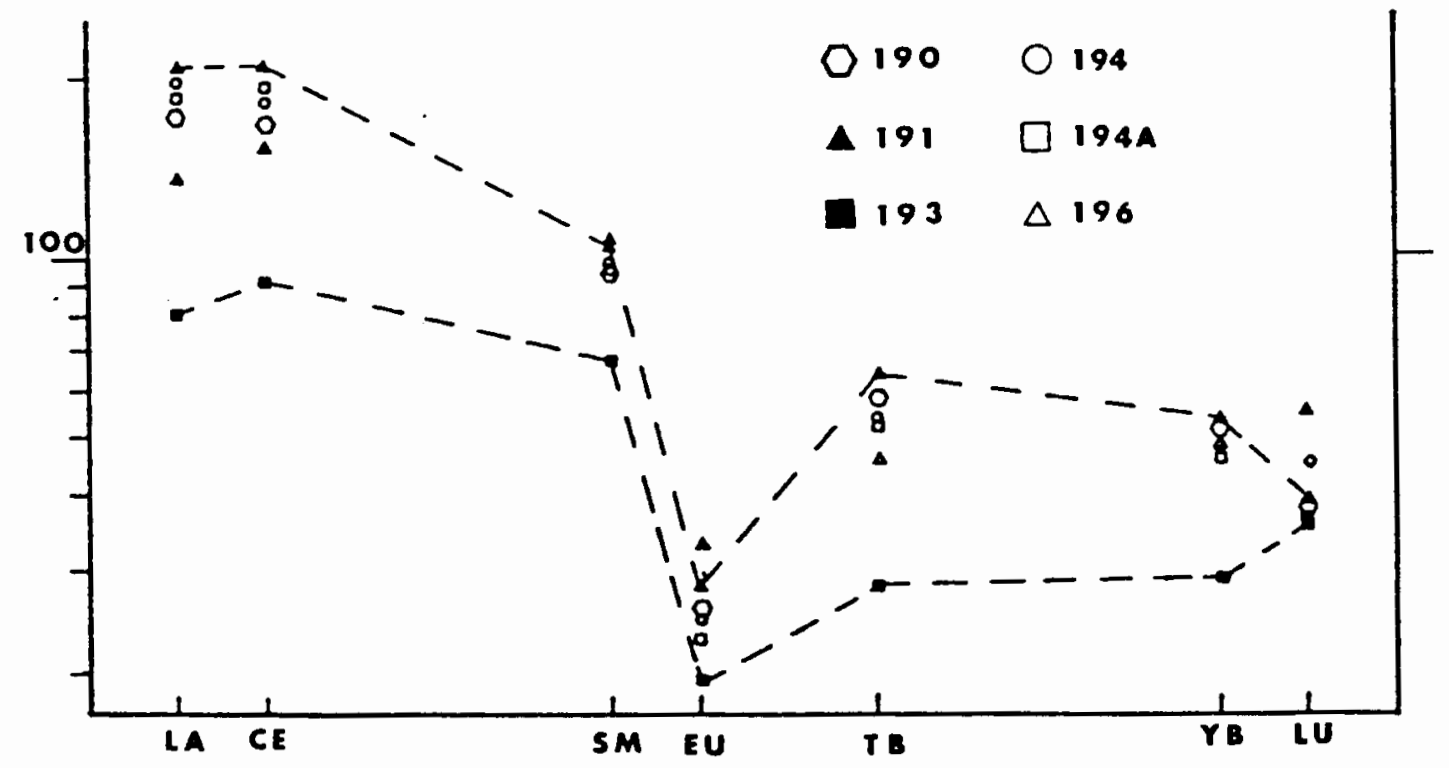

REE graph of samples from uranium prospects.

Figure 16. REE graphs of samples from fumeroles and urañium prospects. 
Berry, 1981) which is also hosted in peraluminous tuffs and rhyolites. Trace element data also suggest differences from the common uranium deposit. Cs concentrations are not enriched as they are at the McDermitt district. Instead, Cs is slightly depleted (appendix C).

The analyses for $U, A s, S b$, and Mo are in ppm except Mo which has been internally normalized. Based on the background concentrations established by $B C B-190$, samples BCB-193, 194, and 196B show the greatest positive anomalies of these elements (Table IV). Uranium concentrations are 6 to 10 times greater in these samples. BCB-196B shows the greatest concentration with $59 \mathrm{ppm}$. The John Day tuff itself contains a higher concentration of $U$ compared to the lithologic units of the Clarno Formation which range from undectectable to $8.4 \mathrm{ppm}$. The local background concentration of $U$ established by $B C B-190$, a sample from the John Day Formation, is $4.9 \mathrm{ppm}$. This indicates that the $U$ in these deposits could be remobilized from tuffs of the John Day. The three samples that are enriched in $U$ are also enriched in Mo. BCB-194 has the greatest concentration which is $25 \%$ greater than the norm, BCB-193. Mo was not detected in BCB-190.

The distribution of As and $\mathrm{Sb}$ at the $\mathrm{U}$ prospects is quite different than that at the mercury prospects. Antimony concentrations average .15 ppm at these prospects. In the mercury prospects the local average concentrations 
ranges from 44 to $13 \mathrm{ppm}$. Antimony depletion corresponds to $U$ enrichment. In the mercury prospects antimony is enriched in areas with $\mathrm{Hg}$ enrichment.

Arsenic concentrations are erratic in the uranium properties and do not create a systematic pattern of distribution. However, samples that are enriched in $U$ are also enriched in As. But the sample with the greatest enrichment in $U$ has the least relative enrichment in As.

Thorium concentrations are depleted with an increase in U. Background concentration is 17.5 ppm. With an increase in $U$, Th concentrations fall to 8.4 in sample $\mathrm{BCB}-193$.

Geochemical data has been supplied by DOGAMI (G. Grey, personal comm.) for several areas that bound the thesis area (Table V). One of these areas lies on the southern extension of the NW-trending faults exposed at the uranium prospects. The samples came from the old White Swan property. A1len (1939 unpub1. DOGAMI report) described the workings on the property and reported on the possible economic value of the gypsum present. Two samples, 392-R0l and 393-ROl, represent jasperoid float and a dump sample repectively. These samples have anomalous concentrations of base metals. Sample 392 is the most anomalous, containing $14 \mathrm{ppm} \mathrm{Pb}, 68 \mathrm{ppm} \mathrm{Zn}$, and $17.1 \mathrm{ppm}$ Mo. Only trace amounts of $\mathrm{Hg}$ and $\mathrm{Ag}$ were detected. The concentration of As is $19 \mathrm{ppm}$, which is close to the 


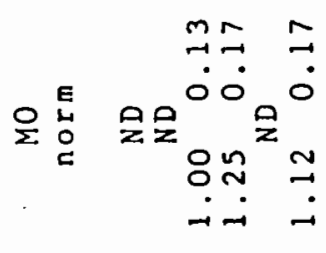

엉요요요 نं0்0ं

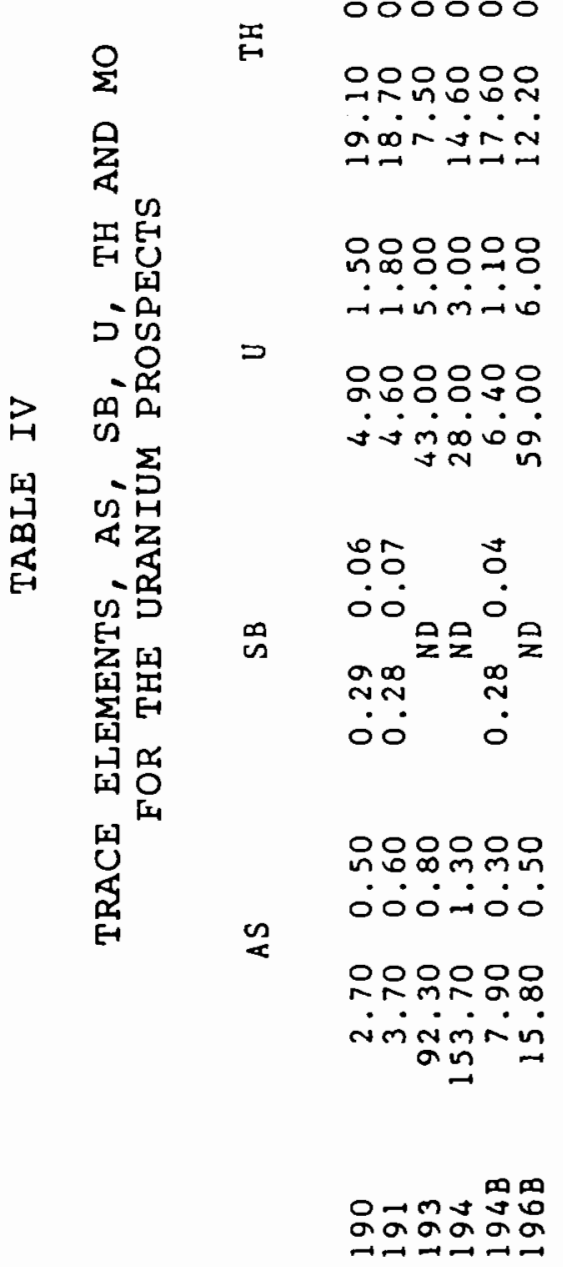

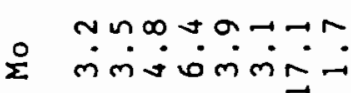

들ํำ

م $\dot{0} \dot{i} \dot{0} \dot{0} \dot{0} \dot{0} \dot{j}$

Dr

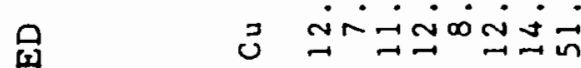

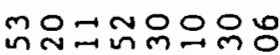

$=$ í0்ட்

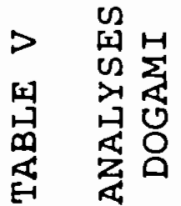

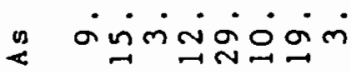

0 m $m \sim \rightarrow \pm m+$

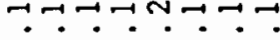

\&

nnNMNnNm

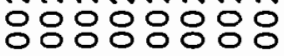
‘ نं00000்

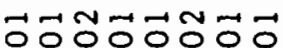

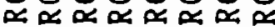
11111111 $\infty \sigma a 0 \rightarrow \sim m$ $\infty \infty \infty$ a a o o $\sigma$ लm लm लm 
concentrations of As found at the sites of uranium enrichment in the John Day tuff in the study area. The enrichment in Mo and As, lack of enrichment in $\mathrm{Hg}$, and the location of the White Swan property along the trace of the fault at the uranium prospects indicate a strong probability that the $U$ and White Swan prospects are related to a common system.

Geochemistry of fumerolic alteration

Samples $B C B-631 A-D$ are grab samples from a traverse across a bleached alteration area on Taylor Butte. Sample BCB-1150 is a grab sample lower on the slope of Taylor Butte where a rhyolite body has intruded a basalt flow. Samples BCB-63, $128 B$, and 129 are grab samples from exploration pits on Bear Creek Butte; representing obsidian, rhyolite breccia and rhyolite repectively. Sample BCB-112 is relatively unaltered rhyolite from Taylor Butte and was used to provide background concentrations (P1ate 2).

Again, REE have been normalized against chondrites (Nakamura, 1974) and plotted in figure 16. A11 samples fall into the category of little to no Eu anomaly (Cullers and Graf, 1984). The REE plots obtained for samples from the two rhyolite domes indicate a close correlation between the samples regardless of which dome the samples are from. This supports petrographic evidence that the two domes are composed of similar flows. 
A 11 of the samples are slightly depleted in REE compared to $B C B-112$. This depletion is most pronounced in BCB-631C, a sample from the center of the bleached area. However, REE ratios (Table II), indicate that this sample follows a trend similar to the rest of the samples except the La/Yb ratio indicates less fractionation of the HREE than in the rest of the samples. The association of REE depletion with bleaching alteration implies that the changes in REE are probably related to changes in the samples due to silica flooding followed by bleaching. However, detailed studies concerning volume and powder densities were not performed and it should be noted that this process is problably responsible for all depletion seen in the fumeroles.

Other trace elements (Table III)indicate similarities among samples. The areas of alteration contains no positive $U$ anomalies. All U concentrations were less than that in $B C B-112(4.85 \mathrm{ppm})$ and suggests $U$ was preferentially leached from the rocks during alteration since the most altered sample, BCB-631C, shows the greatest depletion. Thorium concentrations follow the pattern seen at the uranium prospects; an increase in the concentration of $U$ is associated with a decrease in Th. $\mathrm{BCB}-631 \mathrm{C}$ has the greatest enrichment in $\mathrm{Sb}, 3.5 \mathrm{ppm}$. Locally, background for Sb using sample BCB-112 is near zero. Positive As anomalies are present in 3 samples, BCB 
631C, 1150 , and 128B. The local background concentration is $2.70 \mathrm{ppm}$. The samples with the greatest As anomaly are $\mathrm{BCB}-631 \mathrm{C}, 5.1 \mathrm{ppm}$ and $\mathrm{BCB}-128 \mathrm{~B}$. BCB-1150 is slight $1 \mathrm{y}$ elevated above background, having a concentration of 2.78 ppm, which with error, is indistinguishable from local background.

Hf shows the greatest relative depletion in the area of the greatest bleaching, represented by $\mathrm{BCB}-163 \mathrm{C}$. Concentrations of $\mathrm{Sc}$ indicate a similar depletion in the area of strongest alteration. This depletion of Sc is accompanied by an enrichment at the boundaries of this area.

DOGAMI has provided geochemical data for areas on Taylor Butte and a quarry north of the butte (Table V). This data indicates enrichment in the base metals, of $\mathrm{Pb}$ and $\mathrm{Zn}$ in these areas. $\mathrm{Pb}$ shows the strongest enrichment at the quarry site, sample 388-R0l with $40 \mathrm{ppm}$. The greatest $Z_{n}$ concentration, $193 \mathrm{ppm}$ is in B89-R02. 


\section{CHAPTER IV}

\section{DISCUSSION}

\section{Stratigraphy}

The Bear Creek Butte area has been the site of mafic to felsic volcanism since at least Eocene time. The large majority of the lithologies exposed in the study area belong to the Eocene to Early 01igocene age Clarno Formation. As previously discussed in the section on stratigraphy, 01 es and Enlows (1971) argued that the Clarno Formation contained two dissimilar sequences of rocks and that the Clarno should be elevated to group status. In the area of Mitchel1, Oregon these two different sequences of rocks are separated by an angular unconformity. In that area, erosion had cut deeply into the older rocks of intermediate composition which comprised the lower Clarno Formation. A paleosol of variable thickness had formed at the stratigraphic break. Numerous lava flows, assigned to the upper Clarno, filled the old erosional valleys as intracanyon flows and lapped against paleotopography • These younger lava flows are composed predominat $1 \mathrm{y}$ of andesite. These younger flows appeared to be unaffected by orogenic episodes that deformed the underlying Cretaceous 
and lower Clarno rocks. Few units of felsic composition were found in this area.

Waters and others (1951) and Swanson and Robinson (1968) working $40 \mathrm{~km}$ west of the Mitchell area found, in the area of the Horse Heaven mine, rocks of intermediate composition similar to those described by 0les and Enlows and other workers in the area of Mitchell. Unconformably overlying the more steeply dipping older rocks is a younger sequence of rocks. These younger rocks are flatter lying and are separated from the underlying rocks by a red clayey saprolite. This upper sequence consists of lower most basaltic andesite flows that contain numerous phenocrysts of altered ferromagnesium minerals and, unlike the lower sequence lack plagioclase phenocrysts. Following the eruption of these flows, rhyolite domes and flows and felsic tuffs were emplaced. Disconformably overlying these felsic units are augite andesites which contain zoned plagioclase and augite phenocrysts and scattered xenocrysts of quartz.

In the Bear Creek Butte area the oldest exposed rocks are predominantly basaltic andesite to andesite, although basaltic and dacitic rocks are found in restricted areas and are referred to as the lower sequence of the Clarno Formation. The major oxide geochemistry and petrography indicate that these rocks belong to the high alumina calcalkaline intermediate rock series and fall within the 
fields created by geochemical data for rocks from the Clarno Formation in the Mitchell area (Oles and Enlows, 1971; Novitsky-Evans, 1974; Huggins, 1977; Owen, 1977; Rogers and Novitsky-Evans, 1977a, b). A dark red clayey paleosol of variable thickness has formed from the rocks of the lower sequence and is similar to the paleosols described by Waters and others (1951), Oles and Enlows (1971) and referred to by Rettalack (1981) in other areas where the Clarno Formation crops out. Unconformably overlying the palesol is the upper sequence of rocks composed of rhyolite and basalt lavas and felsic tuffs. This upper sequence is similar to the upper sequence at the Horse Heaven mining district. Sample BCB-195 is petrographically similar to the uppermost andesite described by Waters and others (1951) and may indicate that this andesite in the Bear Creek area is stratigraphically above the felsic and mafic rocks of the upper sequence. The upper sequence of rocks in the Horse Heaven area has been assigned to the Clarno Formation on the basis of work by Swanson and Robinson (1968) based on stratigraphic evidence and an age date of $41.0 \pm 1.2 \mathrm{~m} . \mathrm{y}$. for a porphyritic rhyolite flow at the Horse Heaven mine which is older than 34.2 m.y., the age of a Clarno "nutbed" (Evernden and James, 1964) which is recognized as the top of the Clarno Formation. 
The Clarno Formation and the regional tectonic setting Based on geochemical information it has been stated that the Clarno Formation was formed on a relatively thin continental crust near an area of active subduction similar to a modern volcanic arc (Novitsky-Evans, 1974; Rogers and Novitsky-Evans, 1977 a, b). Geochemical analyses of numerous samples from rocks in the western U.S., performed by Lipman and others (1972), indicated that the subduction zone was to the West. Furthermore the study indicated that the subducting slabs were composed of imbricate plates with a shallow $\left(20-25^{\circ}\right)$ dip.

Work by Armstrong (1978) placed the Clarno Formation within a regional Northwest setting. This study states that the period of time $55-45 \mathrm{~m} . \mathrm{y} . \mathrm{a}$. was a time of regionwide volcanism which Armstrong (1978) labels the Challis episode. Age dates compiled by Fiebelkorn (1983) indicate that the oldest lava flows of the Clarno Formation may be slightly younger than the Challis volcanic sequence. Armstrong (1978) does not speculate on the tectonic setting during this period of time but states whatever tectonic model that is devised must account for the southward migration of volcanic activity in the Northwest and the geochemical data that implies the creation of a volcanic arc sequence near an active subduction zone.

Work by Wells and others (1984) developed and refined a northeast Pacific plate-motion model which provided a 
framework for analysis of the Tertiary volcanic and tectonic history of Oregon and Washington. This study indicated a strong correlation between changes in forearc, back arc, and Cascade arc volcanism and a marked decrease in the rate of Farallon-North America convergence between 43 and $28 \mathrm{~m} \cdot \mathrm{y} \cdot \mathrm{a}$. This slow down may be responsible for the westward stepping of the volcanic arc front from the Challis axis to a Cascade axis at $\sim 42 \mathrm{~m} . \mathrm{y}$. and a period of extensional basaltic and alkalic volcanism in the Coast Range between 44 and $28 \mathrm{~m} \cdot \mathrm{y} \cdot \mathrm{a}$.

Paleomagnetic studies of the Clarno Formation in the Mitchel1 area by Beck and others (1978) indicate that mean paloemagnetic direction for the Clarno Formation is not significantly different from the expected mid-Tertiary magnetic field direction, calculated from the mean midTertiary pole for the North American craton. This implies that the area of Mitchell did not experience any large scale rotation at least since the late Eocence.

The upper sequence of rocks in the study area comprises a bimodal sequence. Most studies relating bimodal volcanism to tectonic regimes (Hughes, 1982 ; Barker, 1983) show a relationship between extension and the eruption of bimodal volcanic suites. This is especially we 11 documented in the western U.S. during the past $13 \mathrm{~m}$. and is related to the formation of the Basin and Range Province (McKee, 1971; Armstrong, 1978; Stewart, 1978 ; 
Christiansen and McKee, 1978). However, no one has documented an extensional regime during the time that the Clarno Formation was deposited (Atwater,1970; Lipman and others, 1972).

Instead of Basin and Range extension being the influencing tectonic regime, a tectonic environment similar to that described by Wells and others (1984) is more likely. Using this mode1 the Clarno developed in the following manner. Most of the Clarno rocks were deposited in a tectonic setting common to volcanic arcs, generating an intermediate volcanic suite but occurring on a thin continental margin. This is the tectonic environment during the transition of volcanism from the Challis axis to the Cascade axis. Through time the erupted material became more silicic, resulting in a change from basaltic to andesitic to dacitic composition. As the tectonic environment changed a hiatus in volcanic activity occurred which resulted in the development of the paleosol. Renewed volcanism erupted the bimodal suite of rocks. This probab1y corresponds to the slow down in the rate of convergence of the North American and Farallon plates which resulted in reduction of the horizontal compressive stress and relaxation of the continental crust. This allowed injection of magma into the continental crust, development of shallow magma chambers and interarc extensional magmatism in the study area and the Horse Heaven mining 
area. During the late period of this change in tectonic environment there is evidence of crustal thickening. A plot constructed by Hughes (1982) of K O vs SiO indicates that sample $B C B-195$, the uppermost andesite, 1 ies between the subaerial andesite series and the more alkaline rocks of the shoshonite series. Shoshonite lavas tend to be generated further landward of the subduction zone or, as the continent over-rides the subduction zone, in an area of thicker crust than calcalkalic lavas. This implies that BCB-195, one of the last flows of the Clarno Formation erupted, was generated on a thicker continental crust than the lavas of the lower Clarno.

This study and those of Waters and others (1951) and Swanson and Robinson (1968) supply evidence of a change in the tectonic environment during the time at which the Clarno Formation was being deposited that is absent in the Mitchell area where most of the studies of the Clarno Formation have been done. The evidence is the presence of a bimodal suite of volcanic rocks found in the study area and the Horse Heaven mining district. The relationship of bimodal volcanism to an environment of tectonic relaxation is well documented. Tectonic relaxation in the Pacific Northwest occurred during the period of a decreased rate of covergence of the North American and Farallon plates, between 43 and $28 \mathrm{~m} \cdot \mathrm{y} \cdot \mathrm{a}$., resulting in a reduction of the horizontal compressive stress and relaxation of the 
continental crust. This slowdown resulted in the westward stepping of the volcanic arc front from the Challis axis to the Cascade axis (We11s and others, 1984).

Only one geochemical analysis is available for the upper most andesite of the Clarno Formation, BCB-195 (appendix 1). The analysis indicates a tendency toward the shoshonite series vs the more calcalkaline rocks of the lower Clarno, indicating that this andesite was generated when the continental crust was thicker than the thinner crust on which the lavas of the lower sequence of the Clarno Formation were formed.

\section{Epithermal systems and hydrothermal a $\underline{\text { alteration }}$}

Numerous authors have studied alteration in hydrothermal systems. Some of the pertinent studies and the processes identified within are discussed in the first portion of this chapter. The implications of these various studies for the mercury and uranium prospects and fumerolic alteration zones in the Bear Creek Butte area are developed. The mineralization history, model for the system and potential for precious metal mineralization are discussed in 1 ight of these observations.

Similar assemblages of hydrothermal minerals have been recognized in active geothermal fields and epithermal minera1 deposits (White, 1967; Browne, 1978; Sawkins, 1984). Several factors affect the formation of 
hydrothermal minerals. However, these factors vary in importance from area to area. These factors are fluid composition, temperature, permeablility, rock type, pressure and duration of activity. Neither composition nor temperature of the hydrothermal fluids were directly determined in this study. However, work by numerous authors, including Roedder (1967), White and others (1971), Taylor (1974), Rose and Burt (1979), Henley and E11is (1983), and Mariner and others (1983), indicate that most epithermal deposits were formed from dilute alkali-chloride solutions (0.5-5 wt. \% NaCl) within a temperature range of 150-300'C. Oxygen isotope studies (Fournier, 1983) indicate that heated meteoric waters are the common hydrothermal fluids. There is no evidence to argue that the mercury mineralization at Bear Creek Butte originated from hydrothermal fluids other than similar dilute solutions.

Studies of alteration in epithermal precious metal and geothermal systems demonstrate a close correlation between hydrothermal mineral depostion and permeability and porosity (Browne, 1978). The porosity and permeability may be related to primary rock textures or to secondary porosity generated along faults, by leaching, or hydrothermal brecciation. Rock type mainly influences the primary permeability and thus the degree to which the hydrothermal fluid can permeate the host rocks. The 
influence of primary permeability may show a strong influence on distribution of alteration and mineralization. The composition of the rock also influences the elements that are present in the alteration mineral assemblages. Although this influence is practically nil in equilibrium assemblages formed above $280^{\circ} \mathrm{C}$ (Browne 1978), the mineral assemblage may be influenced at lower temperatures. However, the role of secondary porosity is commonly more important.

The generation of secondary porosity and permeabilty and self-sealing are influenced by pressure changes which can play an important role in the deposition of hydrothermal minerals. Rapid pressure changes are expressed by episodic boiling caused by a sudden rupturing of an impermeable barrier across which a strong pressure gradient has developed. The rupturing of the barrier results in a drop in confining pressure resulting in violent boiling, development of hydrothermal breccias in the overlying rock and generation of secondary porosity . Violent boiling also changes the composition of the fluid to produce simultaneous deposition of minerals. Composition is changed by a loss of $\mathrm{CO}, \mathrm{H} \mathrm{S}$ and other volatile components to the steam phases. This increases solution salinity and $\mathrm{pH}$ and results in subsurface zones of boiling being characterized by hydrothermal quartz, Kfeldspar, and bladed calcite (Browne and Ellis, 1970; and 
Keith and others, 1978).

The vapor phase rises and oxidation occurs forming $\mathrm{H}_{2} \mathrm{SO}_{4}$ and $\mathrm{H}_{2} \mathrm{CO}_{3}$. Upon cooling, condensation of a fluid from the vapor produces a solution of low $\mathrm{pH}$ and an increase in the hydrolytic activity of the system (Giggenbach, 1981; White, 1981). The acid solution readily leaches the near surface rocks, releasing relatively immobile $\mathrm{K}+$ and $\mathrm{A} 1+$ ions from silicates thus producing secondary kaolinite and, in combination with the silica rich fluids, a silica cap.

The deposited silica forms an impermeable cap sealing the system and thus preventing free movement from a higher to lower pressure area. Thus the self sealing of the system leads to rupture of the barrier as the trapped vapor pressure exceeds the lithostatic pressure, again boiling occurs, and a volatile-rich vapor phase is released and rises.

Recent studies by Hedenquist and Henley (1985) and Nelson and Giles (1985) indicate that substantial fluid overpressures in the upper silicified portion of the hydrothermal system are not required to develop hydrothermal breccias. Instead these studies indicate that only local sealing of near-surface discharge channels and the transmission of deeper reservoir pressures to the sealed area by the evolution of a compressible cap of exsolved gas, predominantly $\mathrm{CO}_{2}$, that is released by the 
violent boiling of the fluid can be the mechanism that creates hydrothermal breccias. Hydraulic fracturing begins with pore-fluid expansion and fractures propagate at depth when the pressure just exceeds the sum of confining pressure plus rock strength (Norton, 1984). At this point the transition from hydraulic fracturing to hydrothermal brecciation becomes a function of available energy in the geothermal reservoir.

The changes in pressure, temperature, $\mathrm{pH}$, salinity, oxygen fugacity and volatile loss that occur at the boiling interface results in the precipitation of base metals at and below the boiling interface. Precious metals which may be transported as thio complexes are deposited above the interface (Ewers and Keyes, 1977).

Fluctuations in the level and thickness of the zone of boiling increase the area over which mineralization can occur. Also laboratory studies by Sondergeld and Turcotte (1979) indicate that the rate of boiling of a mineral-rich fluid affects the rate of mineral deposition. This contradicts previously held assumptions that mineral deposition is associated with a solute that is increasingly concentrated by loss of water to a steam phase, resulting in saturation and precipitation.

Deposition of silica

The presence of quartz as the predominant silica mineral imparts information concerning the hydrothermal 
fluid. The solubility of quartz controls the concentration of dissolved-silica in most geothermal reservoirs above $90^{\circ} \mathrm{C}$ and in a11 with reservoir temperatures $>180^{\circ} \mathrm{C}$. The presence of quartz as the precipitated silica mineral indicates that the solution was not supersaturated with respect to silica (Fournier, 1985). Quartz will precipitate from hydrothermal fluids with an initial temperature above $200^{\circ} \mathrm{C}$ if slow cooling of the fluid occurs. Rapid cooling allows a supersaturated solution to form, particularly if cooling is adiabatic (Fournier, $1985)$.

The precipitation of amorphous siliceous sinter, commonly seen in active geothermal areas, requires that the solution must be supersatured in silica with respect to quartz. Amorphous silica has the same solubility in pure water at $100^{\circ} \mathrm{C}$ as does quartz at $225^{\circ} \mathrm{C}$. Thus water that flows from a reservoir with a temperature below $200^{\circ} \mathrm{C}$ contains so little dissolved silica that the sinter is thin and restricted. No sinter is formed if the reservoir temperature is $<150^{\circ} \mathrm{C}$. If reservoir temperature is $>270^{\circ} \mathrm{C}$ so much silica is contained in the solution that selfsealing of the channel-ways by precipitated silica is common (Fournier, 1985).

\section{Deposition of mercury}

Mercury is a volatile element whose partial pressure 
ranges from .0019 $\mathrm{mm} \mathrm{Hg}$ pressure at $\mathrm{O}^{\prime} \mathrm{C}$ to $17 \mathrm{~mm}$ of $\mathrm{Hg}$ pressure at $200^{\circ} \mathrm{C}$ (White, 1967). Thus Hg is readily transfered to the vapor phase when boiling occurs. During vapor partitioning $\mathrm{Hg}$ is carried in the vapor to the surface as HgS. Several other factors affect the transportation of $\mathrm{Hg}$ in vapor. Work by White (1967), Verakamps and Buseck (1984) and others indicate that a high CO content in this vapor is necessary for Hg transport. 2

Thermal waters containing Hg must be reducing enough to keep $\mathrm{Hg}$ in solutions as $\mathrm{Hg}^{\circ}$ aq (Verakamps and Buseck, 1984). Factors affecting deposition of $\mathrm{Hg}$ from solutions are cooling, or mixing with acidic or oxidizing waters.

The work of Verakamp and Buseck (1984) indicates that cinnabar is unstable in vapor dominated systems; if present in the reservoir it decomposes according to

$$
\mathrm{HgS} \rightarrow \mathrm{Hg}^{\circ} \text { vap }+1 / 2 \mathrm{~S}_{2} \text { vap. }
$$

The $\mathrm{S}_{2}$ vapor will be converted to $\mathrm{H}_{2} \mathrm{~S}$ under reducing conditions common in geothermal systems. This also implies that cinnabar must be precipitated from a fluid phase. However, in hydrothermal systems mercury commonly is present in several forms; as an absorbed state, mercuric sulfide, and as a trace element in pyrite and other sulfides. When mercury is in the vapor phase it can invade rock and soil of high permeability and become absorbed on the surface of particles (Christensen and others, 1983). Deposition of mercury is very temperature dependent, 
becoming deposited in significant amounts at temperatures $<200^{\circ} \mathrm{C}$. Thus the distribution of mercury in the absorbed state is common 1 y restricted to the periphery of the system (Christensen and others, 1983).

Deposition of other elements

Arsenic and antimony are common accessory elements in epithermal precious metal deposits and geothermal systems. Experimental work by Ewers (1977) indicates that Sb and As are readily transported in hydrothermal systems. The presence of As in hydrotherma11y altered areas does not require release of As from a primary magmatic source. For a rock to water ratio of 10 (a conservative estimate) the source rock need contain only 10 ppm As to generate the 2530 ppm measured at New Zealand's geothermal field (Ewers, 1977). Arsenic is 1 iberated from pyrite as it breaks down and releases sulfur.

Antimony differs from arsenic in the temperature range at which it can be released from the host. The percentage of $\mathrm{Sb}$ leached between $50-500^{\circ} \mathrm{C}$ is constant versus As which nearly doubles (Ewers, 1977). This indicates that Sb is absorbed onto crystal phases. Low temperature leaching of short duration generates 1 ittle response. The rate of Sb release is dependent on the way that the $S b$ is held and the rate of the reaction between rock and solution. This implies that for low temperature systems to transport Sb they must be long 1 ived. This laboratory work indicates 
that the amount of $A s$ and $S b$ deposited is related to the strength and/or duration of the hydrothermal system.

\section{Argillic alteration}

In hydrothermally altered rocks kaolinte occurs in both intermediate and advanced argillic alteration zones. In intermediate argillic alteration kaolinite is found in the outer alteration envelope surrounding veins and may be in association with smectite, chlorite, and other clays (Henley and Ellis, 1983). In advanced argillic alteration the host rock is completely altered to kaolinite and quartz (Browne and Ellis, 1970).

Amorphous clays may also be present in the alteration areas. These are materials that are amorphous to x-rays, except for a broad flat diffraction band centering on the cristobilite peak. They appear isotropic to semiopaque in thin section. Amorphous clays may be represented by some of the unidentifiable material seen in thin sections from altered rocks in the study area.

Based on work by Meyers and Hemley (1967) and Eber1 and Hower (1975) important factors in the hydrothermal formation of clays are the Si/Al ratio and the alkali/H+ ratio. These reactions are $H+$ consuming and release alkali cations. This requires low alkali/H+ ratios and weakly acidic pH's for the kaolinite to be produced. The effects of $\mathrm{pH}$ appears to be dominant in hydrolysis reactions 
(Schoen and others 1974) for without sufficient protons available to enter mineral structures and disturb electrically balanced bonding forces most hydrolitic reactions are extremely slow.

Temperature is the next most important factor in overcoming kinetic barriers to reactions and accelerating reaction rates. Steiner (1968), Muffler and White (1969), and Browne and E11is (1970) indicated that the distribution of clay minerals is temperature dependent. Studies by Browne (1978) in the Wairakei geothermal field indicate that surface kaolinite formed at low pH does not persist above $60^{\circ} \mathrm{C}$. Kaolinite and montmorillonite are also associated with advanced argillic alteration common in supergene environments (Meyer and Hemley, 1967).

The relative concentrations of alkaline/H+ ratio and the Si/Al ratio in solutions determine the nature of solid products of hydrolysis. The alkali/H+ ratio must be low for production of kaolinite (Hemley and Jones 1964). Continuing these reactions over a long period of time completely alters the host rock to kaolinite.

\section{Sinter deposits and the paleosurface}

To determine whether the altering fluid was rising or descending the most critical detail to consider is the constructional vs destructional origin of the silica zone. If the siliceous rocks are bedded hot spring deposits overlying the original land surface, this indicates that 
the thermal water table was at the surface. Hypogene alteration probably exists below. However, if the siliceous rocks are altered residues of host rocks, alteration by descending acid solution may be indicated (Schoen and others 1974).

Studies at Steambot Springs, Nevada (White, 1981, 1983) and other sites (Browne and El1is, 1970) indicate that the altering agent is sulfuric acid. The generation of this acid is expressed in the reaction

$$
\mathrm{H}_{2} \mathrm{~S}+2 \mathrm{O}=\mathrm{H}_{2} \mathrm{SO}_{4}
$$

$\mathrm{H} S$ is exsolved from the fluid upon boiling and rises into 2 an oxidizing environment. Studies have indicated that $H S$ rapid 1 y oxidizes to $S^{\circ}$

$$
\mathrm{H} \mathrm{S}_{2}+1 / 2 \mathrm{O}=\mathrm{H}_{2} \mathrm{O}+\mathrm{S}^{\circ}
$$

further oxidation requires high temperature, exotic noblemetal catalysts or both. Studies of soil bacteria in hotspring areas of surficial alteration show the presence of members of the genus Thiobacillus catalyze the oxidates of $\mathrm{H} \mathrm{S}+\mathrm{S}^{\circ}$ to H SO in their life cycle. The rate of acid 2 production by these micro-organisms appears to be sufficient to account for all of the acid found in these areas (Schoen, 1969).

The $\mathrm{H}_{2} \mathrm{SO}_{4}$ is diluted by condensate and rainfall and percolates downward and outward reacting with unstable minerals in the unsaturated zone. At the water table the sulfuric acid is diluted, stopping the argillization 
process.

Mode1 for the hydrothermal system at the cinnabar prospects

In the chapter on stratigraphy the alteration zoning present at the mercury prospects in the Bear Creek area was described. This consists of a silicificed core containing areas of hydrothermal breccia, surrounded by a zone of argillic alteration which grades outward to a weakly a1tered zone. The altertion zones are of varible width. This reflects the variable primary porosity of the host rocks. The host rocks at the Oronogo mine are basaltic andesite flows that contain little primary porosity. The alteration area is restricted to a narrow zone surrounding the faults, an area of increased secondary porosity. At the Platner mine the dominant lithology is a more porous and permeable tuff and the zone of hydrothermal alteration is more widespread, ranging up to $85 \mathrm{~m}$ from the controlling faults.

The presence of secondary silica and kaolinite is common to areas of hydrotherma 1 alteration and indicates acid leaching by hydrothermal fluids. Kaolinite is the dominant clay at the Platner and Orongo mines and kaolinite with smectite occurs at the Admunsen claim. This indicates that the hydrothermal system in the study area was weakly acidic (Meyer and Hemly, 1967) and that the temperature of the solution was relatively low (Browne, 1978) if the 
argillic zone represents the paleosurface. There are other pieces of evidence that indicate the exposed rocks were near the paleosurface at the time of alteration; the presence of fine grained quartz and the psuedomorphic replacement of pyrite by iron oxide and the preservation of primary textures. The complete alteration of the host rock, as seen at the Platner and Admunsen prospects, indicates that the hydrothermal system was active for a long period of time (Hemley and Jones, 1964).

The presence of hydrothermal breccia at the Platner mine and the Admunsen claim indicate that episodic boiling occurred. However, there is a large body of evidence that suggests the system was fluid dominated. The presence of $\mathrm{Hg}$ as cinnabar and its occurence in quartz veins indicates that the system at Bear Creek Butte was not vapor dominated during cinnabar deposition (Verakamp and Buseck, 1984).

The association of cinnabar, hematite, \pm pyrite indicates that deposition of mercury from solutions occurred by mixing of low S solutions with oxidized waters under cooling conditions (Verakamp and Buseck, 1984). The low S content of the solutions is also argued by the lack of alunite in the system, the absence of which White (1967) used to indicate hydrothermal systems that are commonly low in $S$. The presence of quartz as the dominant silica mineral in the area of strong alteration indicates that the hydrothermal fluid was not supersaturated with respect to 
silica (Fournier, 1985).

The heat for driving the hydrothermal systems and the duration of the system are not readily determined in most systems. An original hypothesis of this study was that the heat source was a large intrusion hidden at depth. The field and laboratory research suggests that an immediate heat source may have been the mafic intrusions found in these areas. Several features in the altered areas suggest this. The close spatial association of hydrothermal breccias with the intrusions is noted at the Platner mine and the Admunsen claim. Emplacement of these intrusions along fault zones could produce over steepened therma1 gradients which, in turn, produced hydrofracturing and development of hydrothermal breccias ahead of the advancing intrusions. Such prograding systems were argued by Blakestad and Stanley (1984) as necessary for the formation of economically significant deposits. However, the intrusions are usually found to be felsic rather than basalt as they are at Bear Creek Butte. At the Oronogo mine mafic intrusions were not found and hydrotherma 1 breccias are absent.

Studies by White and others (1971) comparing vapordominated to hot-water hydrothermal systems indicate that vapor-dominated systems require a stronger heat source. The hydrothermal system at Bear Creek Butte appears to be fluid dominated. This implies an upper restriction on the 
temperature range of the migrating fluids and indirectly restricts the size and/or heat generating capacity of the intrusions. This supports the field evidence that the mafic intrusions served as the heat engines for the system. If the episodic boiling occurred near the paleosurface the lack of siliceous sinter indicates that the reservoir temperature was probably below $200^{\circ} \mathrm{C}$ (Fournier, 1985 ). However, the lack of sinter may also be attributed to removal by erosion.

The intrusions have been completely altered after emplacement to a quartz + kaolinite \pm pyrite alteration assemblage which argues that there may be an additional thermal source other than the mafic intrusions because the system continued to operate over a long enough period of time to completely alter these intrusions. Hydrofracturing of the feldspars in the mafic bodies and mylonitic cavities created by the loss of volatiles from the intrusion could not be detected in thin sections since the intrusions were too altered to allow determination of these features.

The duration of the hydrothermal activity is difficult to determine with any precision. However, the presence of certain mineral assemblages and trace elements allow a reasonable approximation of the duration of the system. Strong $\mathrm{Sb}$ anomalies exist in this area. However, low temperature leaching of short duration frees little Sb from the source areas. Since the temperature of the system was 
probably not great enough to develop a vapor dominated system, a relative long duration is required to free enough Sb from source areas to create the present anomalies. Also the reactions that produced kalinite require a relatively long amount of time to convert the host rock to clay. In a system of long duration more ions flow through the system increasing the potential for precipitation of minerals. This is especially helpful for argillization in the Bear Creek Butte area since the temperature which accelerates reaction rates, does not appear to be high. Al1 of these reactions imply a relatively long lived hydrothermal system

The hydrothermal system that formed the mercury prospects at Bear Creek Butte operated in the following manner. Hg was obtained from deep in the system and transported upward in the reducing fluid as $\mathrm{Hg}^{\circ}$ aq along the steeply dipping faults. Episodic boiling occurred and $\mathrm{Hg}$ was released into the vapor phase and transported upward with the volatile-rich fluid. On the periphery mercury was absorbed on particles of the tuff. Mixing with cooler oxygenated water and/or with acidic oxidizing drainback water in the core of the system led to deposition of cinnabar. This was a response to decreased pH, increased $\mathrm{pO}_{2}$ and lowered temperature of the transporting fluid. The initial heat engine that drove the system was the mafic intrusions. As the intrusions rose, probably along 
the weakened zone caused by faulting, the groundwater was heated. As the vapor pressure became greater than the confining pressure violent boiling occurred and the hydrothermal breccias were formed. This episodic boiling created a prograding system common in epithermal mineralization (Blakestad and Stanley, 1984). The intrusions rose to their present position and cooled. As the heat source cooled the temperature gradient driving the system decreased and the prograding system collapsed back upon itself becoming a monotonic system before transport of enough mercury occurred to develop an ore deposit. The collapse of the system is indicated by local overprinting of the argilic zone on the silicified core. However, some source of heat remained driving a weak hydrothermal system that continued to operate, resulting in the silicification and argillization of the intrusions.

Hydrotherma1 alteration at the uranium prospects

The uranium prospects in the study area are located along a northwest-trending fault and hosted in tuffs of the John Day Formation. The uranium prospects are characterized by the geochemical association of $U$ and Mo in the hydrothermal1y a1tered felsic tuffs.

Silicic igneous rocks have relatively high U concentrations when compared to rocks of more mafic compositions and are commonly associated with U occurrences (Walker and Osterwa1d, 1963). Experimenta1 work by 
Zielinski (1981) indicates several factors that affect the rate of removal of $U$ from glassy rocks, including

temperature, pH, grain size, fluid flow rate, glass

composition, and partial pressure [ $\mathrm{pCO} 2$ and p02].

Zielinski's (1981) work indicates that temperature is the most influential variable because variations of $10-20^{\circ} \mathrm{C}$ produce changes that could be equalled only by much more drastic changes in other variables.

Flow rate does not affect the rate of glass dissolution and thus the rate of 1 iberation of $U$ if the solutions are greatly undersaturated in glass components, which is the typical case in natural systems. However, it does exert great influence on the rate of transport of dissolved $U$ to areas of potential concentration. Whole rock permeability aids the transport of dissolved U (Zielinski, 1979, 1980). It also allows more surface area to be exposed to the leaching solution.

Pressure dependency of glass solubility is not evident since relatively incompressible phases (glass and water) are involved and ion mobility is probably governed by processes such as diffusion and convection which are not strongly pressure dependent (Zielinski, 1981).

Experimental studies by Zielinski (1981) indicate that pH fluctuations exert a strong influence on the solubility of SiO ${ }_{2}$ under alkaline conditions. Uranium solubility parallels that of $\mathrm{SiO}_{2}$. Below a pH of 8.5 at $120^{\circ} \mathrm{C}$ 
amorphous $\mathrm{SiO}_{2}$ is relatively insoluble. This implies that neutral pH, the range of most ground and meteoric waters, is not an important influence on the rate of dissolution of $U$, since under these conditions U transport could be accomplished only by the slow process of diffusional transport.

Studies by Zielinski (1982) of the rhyolite ash of the Troublesome Formation in Colorado indicated that the solution present when $U$ was transported from the tuff and deposited as uraniferous secondary silica was an oxidizing, mildy alkaline to mildly saline solution similar to present day groundwater in the West and similar to the transporting fluid at the Lakeview district in south centra1 Oregon (Castor and Berry, 1981).

Deposition of molybdenum

Anomalous concentrations of molybdenum are found in the uranium exploration pits and also at the White Swan property. The White Swan property is located along the extension to the SE of the fault that cuts the John Day tuff and localized the uranium prospects. The previously presented geochemical data indicated the calcalkaline nature of the rocks in the study area. Studies by Westra and Keith (1981) indicate that molybdenum deposits hosted in calc-alkalic rocks are not large producers in comparison to alkalic and Climax-type deposits. Westra and Keith 
(1984) attribute this to several factors. The two most influential are; 1 ) the source of Mo is believed to be the mantle based on geochemical characteristics and isotope data of igneous rocks genetically related to Mo deposits; and 2) high $F$ concentrations in the magma series that strongly enhances Mo enrichment processes by promoting hydrous K-rich silicate melts. White and others (1981) support a magmatic source for the Mo by studies of Sr and $\mathrm{Pb}$ isotope data and Mo, $W$, and $F$ anomalies in the 1ithosphere in which the Mo deposits are located.

Westra and Keith (1981) state that calc-alkaline molybdenum stockwork deposits occur within a magmatic arc in a converging plate margin. However, a compilation by Sawkins (1984) on the tectonic environment of Mo deposits indicates that major Mo deposits develop in areas of transition due to decreased convergence rates and the onset of true back arc rifting. This implies that the tectonic environment of the Mo anomalous areas at Bear Creek Butte was not favorable for the formation of a large Mo deposit.

Mode1 for the formation of the uranium prospects

The host rocks, John Day tuffs and rhyolite of the Clarno Formation, are peraluminous. However, most uranium deposits in North America are hosted in peralkaline rocks (Curtis, 1981; Rytuba and Conrad, 1981; Wallace and Roper, 1981). An analog to the Bear Creek Butte area exists in the Lakeview uranium district. Within this district most 
host rocks are also peraluminous rhyolites and tuffs (Castor and Berry, 1981). These ash flow tuffs and associated sedimentary sequences have been tentatively correlated with the John Day Formation (Castor and Berry, 1981). At Lakeview, secondary mineralization occurs along limonitized and/or silicified shear zones in bleached ashflow tuffs. This alteration mineralogy is similar to that found in the uranium exploration pits at Bear Creek Butte.

In the Lakeview district Castor and Berry (1981) assumed the tuff to be the source of the $U$ based on two lines of reasoning; 1) the great distance of the tuff from the rhyolite domes, which prevents any direct leaching of U from the domes and 2) different overall trace-element geochemistry between the two. Although a John Day tuff and a rhyolite dome of the Clarno Formation are in contact in the Bear Creek Butte area, the trace element geochemisty is notab1y different. REE plots indicate different magmatic sources for the tuffs and the rhyolite, implying that the source of the $U$ is not from the same parent source. Although background concentration of $U$ is nearly the same in both the tuff and the Clarno rhyolite, i.e. 4.9 ppm for the John Day tuff and $4.85 \mathrm{ppm}$ for the rhyolite, there is a pronounced difference in the $U$ concentrations in samples from the exploration pits hosted in rhyolite or felsic tuffs. Samples from an exploration pit in the rhyolite along the same trend as the uranium prospects have $U$ 
concentrations below relative background. At the prospects in the John Day tuff U concentrations are several times greater than background. This implies that the uranium was mobilized in the John Day tuff and leached from the rhyolite and transported to the uranium prospects.

Uranium was probably released by processes similar to that at the Lakeview district; devitrification of glass, either by pneumatolytic activity during cooling or by subsequent heated groundwater circulation. Silicification of the uranium-bearing rocks indicates moderate temperatures. Based on experimental studies by Zielinski (1981) and work by Castor and Berry (1981) at the Lakeview district, the temperature of the transporting fluid was in the $100^{\circ} \mathrm{C}$ range. The permeability of the tuff at Lakeview and in the study area, and thus flow rate of the hydrothermal fluid, is suggested to be relatively high. This allows more surface area to be exposed to leaching by the fluid and the leached $U$ to be transported and concentrated. Although studies indicate $\mathrm{pH}$ is commonly high there are neither the zeolites nor the K-feldspar present at these pits to support the theory of an alkaline transporting fluid.

The Mo concentrations are anomalous for the area but are not anomalous when compared to economic deposits of molybdenum. However, the presence of Mo anomalies combined with the anomalous concentrations of $U$ indicate that a 
reducing environment was present at the site of deposition for these elements (Zielinski, 1981; Westra and Keith, 1984). This environment of deposition is different than the oxidizing environment required for deposition at the mercury prospects. The fault trend at the uranium prospects also differs from the trend at the mercury prospects which is more NNW-NW. These facts indicate that the system that deposited the uranium was not the same as the system from which mercury was deposited.

Age of mineralization

A tenuous bracketing of the time of uranium deposition is constrained by structural evidence. Extension of the NW-trending faults at the uranium prospects to the southeast coincides with a lineation in the basalts on Rodman Rim which is visible on landsat imagery. This lineation is the result of en echelon faults associated with the Brothers fault zone (Lawrence, 1976). The age of the basalt cut by the faults is no older than $6.7 \mathrm{~m} . \mathrm{y}$. based on an age date from basalt at Millican (Wa1ker and Swanson, 1969 and Fiebelkorn and others, 1983). Thus if the faults at the uranium prospects are related to the lineation at Rodman Rim, uranium deposition must have occurred since $6.7 \mathrm{~m} \cdot \mathrm{y} \cdot \mathrm{b} \cdot \mathrm{p}$. However, this relation is tenuous since the faults at the uranium prospects cannot be traced across the valley to the Rodman Rim due to scree 
beneath the rim.

The host rocks at the uranium prospects are tuffs of the John Day Formation. This unit is stratigraphically above the Clarno Formation which is the host formation for the mercury prospects. There is no expression of the fault trend found at the mercury prospects in the overlying basa1ts. This implies that the mercury deposits were formed after deposition of the Clarno Formation and prior to the eruption of the plateau basalts and possibly prior to the formation of the uranium deposits.

\section{Fumerolic alteration}

The alteration attributed to fumeroles is restricted to small areas, $<10 \mathrm{~m}$. sq., located on the flanks of the rhyolite domes of the upper sequence of the Clarno Formation. These areas of alteration are not associated with faults, thus they are distinctly different from the mercury and uranium prospects.

The trace element geochemistry from these areas indicates no positive $\mathrm{U}$ or $\mathrm{Hg}$ anomalies. In fact, with increased alteration $U$ concentrations decrease. This may indicate flooding of the altered areas by silica, which dilutes the host rock and accounts for the U decrease. This argument is further supported by the REE concentrations. Increasing alteration is defined by a decrease of REE concentrations, however, the ratios of $\mathrm{La} / \mathrm{Sm}, \mathrm{Eu} / \mathrm{Sm}$, and La/Yb for fresh and altered rocks are the 
same in all samples (Table III). Further evidence of flooding of the host by silica is the depletion of Hf. With an increase in the degree of alteration Hf concentrations decrease. BCB-631C, the most altered sample analyzed from the fumeroles has the least Hf. These patterns in trace elements are consistent with dilution by addition of mass and this appears to be related to silicification .

The fumerolic alteration is distinct from the other altered areas. The source of elements that were transported in the fluids was the rhyolite that formed the domes. However, the only element that was abundant and readily available for fluid transport was silica which was deposited in the fumeroles.

The heat source of the fumeroles was the dome-forming rhyolites. Although silca-rich rocks retain their heat for a considerable period of time, the previously discussed methods for concentrating trace elements implies that the fumeroles were short lived systems. 


\section{CHAPTER V}

\section{SUMMARY}

The geology of the Bear Creek Butte area supports a division of the Clarno Formation. In the study area the lower sequence is composed of an intermediate volcanic suite which is separated by a well-developed saprolite from the upper sequence, a bimodal volcanic suite. An augitebearing aphyric andesite composes the uppermost unit of the Clarno Formation at Bear Creek Butte. This is similar to the stratigraphy found at the Horse Heaven mine area (Waters and other, 1951; Swanson and Robinson, 1968).

Mineralization and alteration in the Bear Creek Butte area can be attributed to the circulation of hydrothermal fluids along faults. This is indicted by the restriction of both mercury and uranium prospects along faults. In the mercury prospects the alteration is characterized by a propylitic halo surrounding an area of intense argillization and a core of pervasive silicification and quartz veining. The host rocks are basalt, basaltic andesite, and/or felsic tuffs. Present at both the Platner mine and the Admunsen claim are hydrothermal breccias. These breccias are spatially associated with the zone of 
intense silicification and with mafic intrusions. The intrusions are located along the faults and are completely altered. Heat to drive the system was furnished in part by the mafic intrusions.

Episodic boiling formed the hydrothermal breccias and released Hg into the vapor phase. The mercury percolated upward and was adsorbed onto fragments of the host rock forming the mercury halo seen at the prospects. Cinnabar is found in quartz veins that cut previously altered rock. This relationship indicates, at least in the later stages, that the system was fluid dominated. A fluid dominated system implies a lower temperature than that required for a vapor dominated system. Thus the heat to drive the system could have been furnished by the mafic intrusions. However, these intrusions are completely altered. Also, the large Sb anomalies and the intense kaolinization imply a long lived system. This implies that another heat source may have been present at depth and continued to drive the system allowing complete alteration of the intrusions and kaolinization of the host rock.

Deposition of uranium requires a reducing environment, indicating that another system was also active in the Bear Creek Butte area. Mineralization occurs along limonitized and/or silicified shear zones in bleached ash-flow tuffs of the John Day Formation. The source of the uranium appears to be both the John Day tuff and dome-forming rhyolite of 
Bear Creek Butte.

Structural evidence suggests that the fault along which the uranium prospects are located may post date the deposition of the basalt of the High Lava Plains. This implies that the uranium prospects may have formed less than $6.7 \mathrm{~m} . \mathrm{y} \cdot \mathrm{a}$. The controlling structures of the mercury deposits apparent 1 y do not cut the basalt of Rodman Rim. This implies that the mercury deposits probably formed before the basalt of Rodman Rim was emplaced and thus before the uranium was deposited.

\section{CONCLUSIONS}

1) In the Bear Creek Butte area the Clarno Formation can be divided into a lower sequence composed predominant $1 \mathrm{y}$ of basaltic andesite flows with intercalated mudflows and volcaniclastic sediments and an upper sequence of rhyolite and basalt flows and felsic tuffs. Separating the two units is a paleosol. The upper-most unit may be an augitebearing aphyric andesite.

2) The change from intermediate to bimodal volcanism in the Clarno Formation reflects a change in the tectonic environment within a volcanic arc from compressional to extensional possibly caused by a decreasing rate of subduction to the west.

3) Cinnabar is found in quartz veinlets that cut hydrothermally altered areas. The altered areas are 
composed of silicified hydrothermal breccias surrounded by a zone of argillic alteration and located along NW-NNWtrending faults. The hydrothermal system responsible for the deposition of the cinnabar was fluid dominated and of low to moderate temperature. However, the presence of mercury and silica flooding of the tuffs indicated that the system may have been vapor dominated prior to emplacement of the quartz veins. Deposition of mercury requires an oxidizing environment. Precious metal mineralization may exist at depth but was not detected by geochemical analysis of surface samples.

4) Uranium mineralization is hosted in tuffs of the John Day Formation. Hydrothermal alteration at these prospects is similar to that found at the mercury prospects. However, the uranium was deposited under reducing conditions.

5) Timing of the mineralization is uncertain. Mineralization at the mercury prospects probably occurred prior to emplacement of the basalts of the High Lava Plains. Mineralization at the uranium prospects may have occurred after emplacement of the basalts of the High Lava P1ains. 


\section{REFERENCES CITED}

A11en, J. E., 1939, White Swan property evaluation: unpub. Oregon Dept. of Geol. Min. Industr. Report. 2 p.

Armstrong, R. L., 1978, Cenozoic igneous history of the U.S. Cordillera from lat. $42^{\circ}$ to $49^{\circ} \mathrm{N}$; in R. B. Smith and G. P. Eaton eds. Cenozoic tectonics and regional geophysics of western Cordillera: Geol. Soc. Amer. Memoir 152 , p. 1-24.

Atwater, T., 1970, Implications of plate tectonics for the Cenozoic tectonic evolution of western North America: Geol. Soc. Amer. Bu11., v. 81, p. 3513-3535.

Baldwin, E. M., 1976, Geology of Oregon: Kendall/Hunt Públ. Co:, $147^{\circ} \mathrm{p}$.

Barker, D. S., 1983, Igneous Rocks: Prentice-Hal1 Inc. NY, $417 \mathrm{p}$.

Beane, R. E., 1982, Hydrothermal alteration in silicate rocks; in Titley, S. R., ed., Advances in Geology of the Porphyry Copper Deposits: Univ. Ariz. Press, p. $117-137$.

Beck, J. R., Engelbretson, M. E., Gromme, C. S., Taylor, E. M., and Whitney, J. W., 1978, Paleomagnetism of the middle Tertiary Clarno Formation, North-central Oregon: Constraints on models for tectonic rotation: EOS abst., p. 1058 .

Berger, B. R., and Eimon, P. I., 1983, Conceptual models of epithermal precious metal deposits; in Shanks, W. C. III, ed., Cameron Volume on Unconventional Mineral Deposits, AIME, p. 191-205.

Berggren, W. A., Kent, D. V., F1ynn, J. J., and vanCouvering, J. A., 1985, Cenozoic geochronology: Geol. Soc. Amer. Bull., v. 96, p. 1407-1418.

Berri, D., A., 1982, Geology and hydrothermal alteration, Glass Buttes, southeast Oregon: unpub. Masters thesis, Portland State Univ., Portland, OR, 125 p. 
Blakestad, R. B. and Stanley, W. R., 1984, Monotonic and prograding geothermal systems and precious metal deposits [abst.]: Exploration for ore deposits of the North American Cordillera; [abst.] Symp. of Assoc. of Explor. Geochemists, Reno, Nev., p. 34 .

Boyle, R. W., 1974, The use of major elemental ratios in detailed geochemical prospecting utilizing primary halos: J. Geochem. Explor. v. 3, p. 345-369.

Boyle, R. W., and Jonasson, I. R., 1973, The geochemistry of arsenic and its use as an indicator element in geochemical prospecting. J. Geochem. Explor., v. 2, p. $251-296$.

Brookes, H. C., 1963, Quicksilver in Oregon; Oreg. Dept. of Geol. Min. Ind. Bull., v. 55, 223 p.

Browne, P. R. L., 1978, Hydrothermal alteration in active geothermal fields: Ann. Rev. Earth Planet. Sci., v. 6, p. 229-250.

Browne, P. R. L., and E11is, A. J., 1970, The OhakiBroadlands hydrothermal area, New Zealand: Mineralogy and related geochemistry: Am. J. Sci., v. 269, p. $97-131$.

Buchanan, L. J., 1981, Precious metal deposits associated with volcanic enviroments in the southwest: in Dickison, W. R., and Payne, W. D., eds. Relations of Tectonics to Ore Deposits in the Southern Cordillera: Ariz. Geol. Soc. Digest, v. 14, p. 237-262.

Burnett, J. L., 1986, The Mclaughlin mine, Napa, Yolo, and Lake Counties: California Geology, Jan., 1986, p. $15-16$.

Calkins, F. C., 1902, A contribution to the petrography of the John Day Basin: Calif. Univ. Pub., Dept. Geol. Bu11., v. 3, p. 109-172.

Castor, S. B., and Berry, M. R., 1981, Geology of the Lakeview uranium district, Oregon, in Goodell, P. C., and Waters, A. C., ed., Uranium in Volcanic and Volcaniclastic Rocks: AAPG Studies in Geology \#13, p. 55-62.

Chaney, R. W., 1927, Geology and paleontology of the Crooked River Basin, with special reference to the Bridge Creek flora: Carnegie Inst. Wash., Contrb. Paleontology Publ. 346, p. 45-138. 
Christensen, O. D., Capuano, R. A., and Moore, J. N., 1983, Trace-element distribution in an active hydrothermal system, Roosevelt hot spring thermal area, Utah: J. Volc. Geothrm. Res., v. 16, p. 99-129.

Christiansen, R. L., and McKee, E. H., 1978, Late Cenozoic volcanic and tectonic evolution of the Great Basin and Columbia Intermontane regions: in R.B. Smith and G.P. Eaton eds. Cenozoic tectonics and regional geophysics of western Cordillera: Geol. Soc. Amer. Memoir 152, p. 283-311.

C1ark, A. M., 1984, Mineralogy of the rare earth elements; in Henderson, P.,ed., Rare Earth Elements in Geochemistry: E1sevier, p., 33-62.

Coats, R. R., 1968, Basa1tic andestites: in Hess, J. E., and Poldevart, H. M., eds., Basalts v. 2, Interscience, p. 687-736.

Coleman, R. G., 1949, John Day Formation in the Picture Gorge quadrangle, Oregon: unpub. M.S. thesis, Oregon State College, Corvallis, OR, $211 \mathrm{p}$.

Condon, T., 1902, The Two Islands, Portland, Oreg. $211 \mathrm{p}$.

Cullers, R. L., and Graf, J. L., 1984, Rare earth elements in igneous rocks of the continental crust: intermediate and silicic rock-ore petrogenesis, in Henderson, P., ed., Rare Earth Element Geochemistry: E1sevier, p. 275-316.

Curtis, L., 1981, Uranium in volcanic and volcaniclastic rocks- Examples from Canada, Australia, and Italy, in Goodel1, P. C., and Waters, A. C., eds., Uranium in Volcanic and Volcaniclastic Rocks: AAPG Studies in Geology \#13, p 37-54.

Eber1, D. and Hower, J., 1975, Kaolinite synthesis: The role of $\mathrm{Si} / \mathrm{Al}$ and (alkali)/H+ ratios in hydrothermal systems: Clays and Clay Minerals, v. 23, p. 301-309.

Evernden. J. F., and James, G. T., 1964, Potassium-argon dates and the Tertiary floras of North America: Amer. J. Sci.v. 262, p. 945-974.

Ewers, G. R., 1977, Experimental hot water-rock interaction and their significance to natural hydrothermal systems in New Zealand: Geochim. et Cosmochim. Acta, v. 41, p. 143-150. 
Ewers, G. R., and Keyes, R. R., 1977, Volatile and precious metal zoning in the Broadlands geothermal field, New Zealand: Econ. Geol., v. 72, p. 1337-1354.

Fiebelkorn, R. B., Walker, G. W., MacLeod, N. S., McKee, E. H., Smith, J. G., 1983, Index to K-Ar determinations for the state of Oregon: Isochron/west, v. 37, p. $13-50$.

Fisher, R. V., and Wilcox, R. E., 1960, The John Day Formation in the Monument quadrangle, Oregon: U.S. Geol. Surv. Prof. Paper 400B, p. B302-B304.

Fournier, R. O., 1983, Active hydrothermal systems as analogues of fossil systems: Geotherma1 Resr. Counc., Spec. Rept. \#13, p. 263-284.

1985, Silica minerals as indicators of conditions during gold deposition: U.S. Geol. Surv. Bu11. 1646, p. $15-26$.

Frey, F. A., 1980, Applications of neutron activation analysis in mineralogy and petrology, in, Muecke, G. K., ed., Short Course in Neutron Activation Analysis in the Geosciences: Mineral. Assoc. Can., p. $167-210$.

Garcia, M. O., 1978, Criteria for the identification of ancient volcanic arcs: Earth Sci. Rev., v. 14, p. $147-165$.

Geological Society of America, 1963, Rock-color chart.

Giggenbach, W. F., 1981, Geothermal minera1 equilibria: Geochim. et Cosmochim. Acta, v. 45, p. 393-410.

Giles, D. L., and Nelson, C. E., 1983, Principal features of epithermal lode gold deposits of the circumPacific Rim: Circum-Pacific Energy and Minerals Resource Conf. Proc., p. 243-265.

Hart, W. K., Aronson, J. L., Mertzman, S. A., 1984, Area1 distribution and age of low-K, high-alumina olivine tholeiitte magmatism in the northwest Great Basin: Geol. Soc. Amer. Bu11., v. 95, p.186-195.

Hay, R. L., 1962, Origin and diagenetic alteration of the lower part of the John Day Formation near Mitchel1, Oregon, in Petrologic studies: A volume in honor of A.F. Buddington: Geol. Soc. Amer., p. 191-216. 
Hay, R. L., 1963, Stratigraphy and zeolitic diagenesis of the John Day Formation of Oregon: Calif. Univ. Pub1. Geol. Sci., v. 42, p. 199-261.

Hemley, J. J., and Jones, W. R., 1964, Chemical aspects of hydrothermal alteration with emphasis on hydrogen metasomatism: Econ. Geol., v. 59, p. 538-569.

Henley, R. W., and Ellis, A. J., 1983, Geothermal systems, ancient and modern: a geochemical review: Earth Sci. Reviews, v. 19, p. 1-50.

Hendenquist, J. W., and Henley, R. W., 1985, Hydrothermal eruptions in the Waiotapu geothermal system, New Zealand: Their origins, associated breccias and relation to precious metal mineralization: Econ. Geol., v. 80, p. 1640-1668.

Hildreth, W. and Mahood, G., 1985, Correlation of ash-flow tuffs: Geol. Soc. Amer. Bull., V. 96, p. 968-974.

Huggins, J. W., 1977, Geology of a portion of the Painted Hills quadrangle, Wheeler County, north central Oregon: unpub. M.S. thesis, Oregon State Univ., Corvallis, OR, $123 \mathrm{p}$.

Hughes, C. J., 1982, Igneous Petrology: Elsevier Scientific Pub1. Co., 551 p.

Humphris, S. E., 1984, The mobility of the rare earth elements in the crust; in Henedrson, P., ed., Rare Earth Element Geochemistry, Elsevier, p. 317-342.

Irvine, T. N., and Baragar, W. R., 1971, A guide to the chemical classification of the common volcanic rocks, Can. J. Earth Sci., v. 8, p. 523-548.

Johnson, M., J., 1984, Geology, alteration, and mineralization, of a silicic volcanic center, Glass Buttes, Oregon: unpub. M. S. thesis, Portland State Univ., Portland. OR, 129 p.

Keith, T. C., White, D. E., and Beeson, M. H., 1978, Hydrothermal alteration and selfsealing in $Y-7$ and $Y-$ 8 drillholes in northern part of Upper Geyser Basin, Yellowstone National Park, U.S. Geol. Surv. Prof. Paper 1054A, 26 p. 
Kleinhans, L. C., Balcells-Baldwin, E. A., and Jones, R.

E., 1984, A paleogeographic reinterpretation of some Middle Cretaceous units, North-central Oregon:

evidence for a submarine turbidite system: in Nilsen, T. H., ed., Geology of the Upper Cretaceous Hornbrook Formation, Oregon and California, Pacific Sect. S.E.P.M., v. 42, p. 239-257.

Knowlton, F. H., 1902, Fossil flora of the John Day Basin, Oregon: U.S. Geol. Surv. Bu11. 204, 153 p.

Kuno, H., 1960, High alumin basalt: J. Petrol. v. 1, p. $121-145$.

, 1968, Differentiation of basalt magmas, in Hess, H. H., and Poldervaart, A., eds., Basalts, v. 2, Interscience, p. 2623-2688.

Lawrence, R. D., 1976, Strike-slip faulting terminates the Basin and Range province in Oregon: Geol. Soc. Amer. Bul1., v. 87, p. 846-850.

Levinson, A. A., 1980, Introduction to Exploration Geochemistry, Second Edition: Applied Publishing Ltd . , 924 p.

Lindgren, W., 1933, Mineral Deposits: 4th ed. McGraw and Hi11, New York, 721 p.

Lipman, P. W., Prostka, H. J., and Christiansen, R. L., 1972, Cenozoic volcanism and plate tectonic evolution of the western United States: 1, Early and middle Cenozoic: Royal Soc. Lond. Phil. Trans. ser. A, v. 271, p. $217-248$.

Lowry, W. D., 1940, The geology of the Bear Creek area, Crook and Deschutes Counties, Oregon: unpubl. M.S. thesis, Oregon State College, Corvallis, OR, 29 p.

MacDonald, G. A., 1968, Composition and origin of Hawaiian lavas: Geo1. Soc. Amer. Memoir 116, p. 477-522.

Mariner, R. H., Presser, T. S., and Evans, W. C., 1983, Geochemistry of active geothermal systems: Geothermal Resources Council, Spec. Rept. \#13, p. 95-121.

Marsh, D. C., 1875, A notice of new tertiary mammals IV: Amer. J. Sci., v.9, p. 95-121. 
McKee, F. H., 1971, Tertiary igneous chronology of the Great Basin of the Western United States-Implications for the tectonic models: Geol. Soc. Amer. Bull. v. 82 , p. 208-285.

Merriam, J. C., 1901, A contribution to the geology of the John Day Basin: Univ. Calif. Pub. Geol. Sci., v. 2, p. 208-285.

Meyers, C., and Hemley, J. J., 1967, Wall rock alteration, in H. L. Barnes, ed., Geochemistry of Hydrothermal Ore Deposits: Wiley and Sons, p. 166-236.

Moller, P., and Morteani, G., 1983, On the geochemical fractionation of REE during the formation of Caminerals and its application to problems of the genesis of ore deposits; in Augustithus, S. S., ed., Trace Elements in Petrogenesis: Theophrustus Pub1., p. $747-792$.

Moore-Lewy, G., 1983, Contribution to the knowledge of the igneous rocks of Leinster; in Augustithus, S. S., ed., Trace Elements in Petrogenesis: Theophrustus Pub1., p. 215-232.

Mote, R.H., 1940, The paleontology of the Neidigger flora: unpub1. M.S. thesis, Oregon State College, Corvallis, OR, $32 \mathrm{p}$.

Muffler, L. J. P., and White, D. E., 1969, Active metamorphism of Upper Cenozoic sediments in the Salton Sea geothermal field and the Salton Trough, southeastern California: Geol. Soc. Amer. Bull., v. 80 , p. $157-182$.

Nakamura, M., 1974, Determination of REE, Ba, $\mathrm{Fe}, \mathrm{Mg}, \mathrm{Na}$, and $\mathrm{K}$ in carbonaceous and ordinary chondrites:

Geochim Cosmochim. Acta, v. 38, p. 757-775.

Nelson, C. E., and Giles, D. L., 1985, Hydrothermal eruption mechanisms and hot spring gold deposits: Econ. Geol., v. 80, p. 1633-1639.

Norton, D. L., 1984, Theory of hydrothermal systems: Ann Rev. Earth Planet. Sci., v. 12, p. 155-177.

Novitsky-Evans, J. M., 1974, Petrochemical study of the Clarno Group: Eocene-01igocene continental margin volcanism of north-central Oregon: unpubl. M.S. thesis, Rice Univ., Houston, TX, 98 p. 
Oles, K. F., and Enlows, H. E., 1971, Bedrock geology of the Mitchell Quadrangle, Wheeler County, Oregon: Oreg. Dept. Geol. Min. Indust. Bul1. 72, 62 p.

Owen, P. C., 1977, An examination of the Clarnoformation in the vincinity of the Mitchell fault, Lawson Mountain, and Stephenson Mountain area, Jefferson and Wheeler Counties, Oregon: unpub1. M.S. thesis, Oregon State Univ., Corvallis, OR, 166 p.

Peck, D. L., 1961, John Day Formation near Ashwood, northcentral Oregon: U.S. Geol. Surv., Prof. Paper 424D, p. D153-D156.

1964, Geologic reconnaissance of the Antelope-

Ashwood area, north-central Oregon, with emphasis on the John Day Formation of late Oligocene and early Miocene age: U.S. Geol. Surv. Bul1. 1161-D, P. D1D26.

Rettallack, G., 1981, Preliminary observations on fossil soils in the Clarno Formation (Eocene to early Oligocene) near Clarno, Oregon: Oregon Geol., v. 43, p. $147-150$.

Robinson, P. T., 1969, High titanium alkali-olivine basalts of north-central Oregon, U.S.A.: Contrib. Mineral. Petro1., v. 22, p. 349-360.

Roedder, E., 1967, Origins of fluid inclusions and changes that occur after trapping; in Barnes, H. L., ed., Geochemistry of Hydrothermal Ore Deposits: Wiley and Sons, p. 515-574.

Rogers, J. J. W., and Novitsky-Evans, J. M., 1977a, The Clarno Formation of central 0regon, U.S.A.,-Volcanism on a thin continental margin: Earth Planet. Sci. Letters, v. 34, p. 56-66.

1977b, Evolution from oceanic to continental crust in northwestern U.S.A.: Geophys. Resr. Letters, v. 4, p. 347-350.

Rogers, J. J. W., Burchfield, B. C., Abbott. E. W., Anepoh1, J. K., Ewing, A. H., Koehnken, P. J., Novitsky-Evans, J. M., and Talukdar, S. C., 1974, Paleozoic and Lower Mesozoic volcanism and continental growth in the western United States: Geol. Soc. Amer. Bul1., v. 85, p. 1913. 
Rogers, J. J. W., and Ragland, P. C., 1980, Trace elements in continental-margin magmatism: Part 1 Trace elements in the Clarno Formation of central Oregon and the nature of the continental margin on which eruption occurred; Summary: Geol. Soc. Amer. Bull., v. 91, p. 196-198.

Rose, A. W., and Burt, D. M., 1979, Hydrothermal alteration, in H.L. Barnes ed., Geochemistry of Hydrothermal Ore Deposits, Wiley and Sons, p. $173-236$.

Ross, C. S., and Smith, R. L., 1961, Ash flow tuffs; their origins, geologic relations and identification: U.S. Geol. Surv. Prof. Paper 366, 81 p.

Rytuba, J. J, and Conrad, W. K., 1981, Petrochemical characteristics of volcanic rocks associated with uranium deposits in the McDermitt Caldera Complex, in Goodell, P. G., and Waters, A. C., eds., Uranium in Volcanic and Volcaniclastic Rocks: AAPG Studies in Geology \#13, p. 63-72.

Sawkins, F. J., 1984, Metal Deposits in Relation to Plate Tectonics: Springer-Verlag, 233 p.

Schafer, M., 1956, Uranium prospecting in Oregon, 1956: Ore-bin, v. 18, p. 101-118.

Schoen, R., 1969, Rate of sulfuric acid formation in Yellowstone National Park: Geol. Soc. Amer. Bull., v. 80, p. 643-650.

Schoen, R., White, D. E., and Hemley, J. J., 1974 , Argillization by descending acid at Steamboat Springs, Nevada: Clays and Clay Min., v. 22, p. $1-22$.

Scott, R. A., 1954, Fossil fruits and seeds from the Eocene Clarno Formation of Oregon: Paleontographica, v. 96, pt.B, p. 66-97.

Silberman, M. L., 1983, Geochronology of hydrothermal alteration and mineralization: Tertiary epithermal precious metal deposits in the Great Basin: Geothermal Resrc. Counc. Spec. Rept. \#13, p. 287-304.

Silberman, M. L., Stewart, J. H., and McKee, E. H., 1976, Igneous activity, tectonics and hydrothermal precious-metal mineralization in the Great Basin during Cenozoic time: Soc. Mining Engineers Trans., v. 260 , p. 253-263. 
Sondergeld, C. H., and Turcotte, D. L., 1979, A laboratory study of mineral deposition in a boiling environment: Econ. Geol., v. 74, p. 109-115.

Steiner, A., 1968, Clay minerals in hydrothermally altered rocks at Wairakei, New Zealand: Clays Clay Min., v. 16 , p. 193-213.

Stewart, J. H., 1978, Basin and range structure in western North America: A review: in Smith, R. B., and Eaton,G. P., eds., Cenozoic tectonics and regional geophysics of the western Cordillera, Geol. Soc. Amer. Memoir 152, p. 1-42.

Swanson, D. A., 1969, Reconnaissance geologic map of the east half of the Bend quadrangle, Crook, Wheeler, Jefferson, Wasco, and Deschutes counties, Oregon: U.S. Geo1. Surv., I-568.

Swanson, D. A., and Robinson, P. T., 1968, Base of the John Day Formation in and near the Horse Heaven mining district, north-central Oregon: U.S. Geol. Surv. Prof. Paper \#600, p. D154-D161.

Taylor, H. P., Jr., 1974, The application of oxygen and hydrogen isotope studies to problems of hydrothermal alteration and ore deposition: Econ. Geol., v. 69, p. 843-883.

Tooker, E., W., 1985, Discussion of the disseminated-goldore-occurrence, in Tooker, E., W., ed., Geologic characteristics of deiment-and volcanic-hosted disseminated gold deposits - Search for an occurence model: U.S. Geol. Surv. Bul1,, v. 1646, p. 107-149.

Uppuluri, V. R., 1974, Prineville chemical type: A new basalt type in the Columbia River Group: Geol. Soc. Amer. Bul1., v. 85, p. 1315-1318.

Varekamps, J. C., and Buseck, P. R., 1984, The speciation of mercury in hydrothermal systems, with applications to ore deposition: Geochim. et Cosmochim. Acta, v. 48 , p. $177-185$.

Walker, G. W., 1969, Geology of the High Lava Plains province: Oregon Dept. Geol. Min. Indust. Bul1. 64, p. $77-79$.

1974, Some implications of Late Cenozoic volcanism to geothermal potential in the High Lava Plains of south-central Oregon: Ore-bin, v. 36, p. 109-119. 
Walker, G. W., and 0sterwald, F. W., 1963, Introduction to the geology of uranium-bearing veins in the coterminous United States: U.S. Geol. Surv. Prof. Paper 455A, $120 \mathrm{p}$.

Walker, G. W., and Swanson, D. A., 1969, Discussion of Late Cenozoic mesa basalt sheet in northwestern U.S., by H. E. Wheeler, and H. A., Coombs: Bull. Volcq., v. 32 , p. 581-585.

Wallace, A. B., and Roper, M. W., 1981, Geology and uranium deposits along the northwestern margin, McDermitt caldera complex, Oregon; in Goodel, P. G., and Waters, A. C., eds., Uranium in Volcanic and Volcaniclastic Rocks: AAPG Studies in Geology \#13, p. $73-80$.

Waters, A. C., 1954, John Day Formation west of its type locality [abst.]: Geol. Soc. Amer. Bull.v. 65, p. 1320 .

Waters, A. C., Brown, R. E., Staples, L. W., Walker, G. W., and Williams, H., 1951, Quicksilver deposits of the Horse Heaven mining district, Oregon: U.S. Geol. Surv. Bul1.969E, p. E105-E149.

Weidenheim, J. P., 1980, The petrography, structure, and stratigraphy of Powell Buttes, Crook County, central Oregon: unpubl. M.S. thesis, Oregon State Univ., Corvallis, OR, p. 131 .

Wells, R. E., Engebretson, D. C., Snavely, P. D., Jr., and Coe, R. S., 1984, Cenozoic plate motions and the volcano-tectonic evolution of western Oregon and Washington: Tectonics, v. 3, p. 275-294.

Westra, G., and Keith, S., 1981, Classification and genesis of stockwork molybdenum deposits: Econ. Geol., v. 76, p. $844-874$.

White, D. E., 1967, Mercury and base metal deposits with associated thermal and mineral waters; in Barnes, H. L., ed., Geochemistry of Hydrothermal Ore Deposits, Wiley and Sons, p. 575-631.

1981, Active geothermal systems and hydrothermal ore deposits; in Skinner, B. J. ed., Econ. Geol., 75 th Anniv. Vol., p. 392-423. 
White, D. E., 1983, Steamboat Springs geothermal area guidebook: Geothermal Resrc. Counc. Symp., Role of Heat in the Development of Energy and Mineral Resources in the Northern Basin and Range Province, 45. p.

White, D. E., Muffler, L. J. P., and Truesde11, A. H., 1971 , Vapor-dominated hydrothermal systems compared with hot-water systems: Econ. Geo1. v. 66, p. 75-97.

Wilkinson, W. D., and Oles, K. E., 1968, Stratigraphy and paleoenvironments of Cretaceous rocks, Mitchell quadrangle, Oregon: AAPG Bul1., v. 52, p. 129-161.

Zielinski, R. A., 1979, Uranium mobility during interaction of rhyolitic obsidian, perlite, and felsite with alkaline carbonate solution: $\mathrm{T}=120^{\circ} \mathrm{C}, \mathrm{P}=210 \mathrm{~kg} / \mathrm{sq} \mathrm{cm}$ : Chem. Geol., v. 27, p. 47-63.

1980, Uranium in secondary silica: a possible exploration guide: Econ. Geol., v. 75, p. 592-602.

1981, Experimental leaching of volcanic glass: implications for evaluations of glassy volcanic rocks as sources of uranium; in Goodel1, P. C., and Waters, A. C., eds., Uranium in Volcanic and Volcaniclastic Rocks: AAPG Studies in Geology \#13, p. 1-11.

1982, The mobility of uranium and other elements during alteration of rhyolite ash to montmorillonite: a case study in the Troublesome Formation, Colorado, U.S.A.: Chem. Geol., v. 35, p. 185-204. 


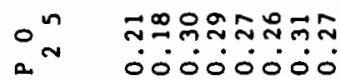

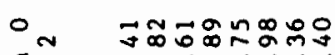 \\ 2 \\ เที่ำำำำ \\ ○00000000 \\ ถุษ

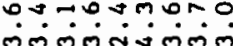

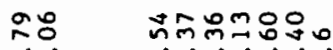 \\ $\therefore \circ$ ००न0000

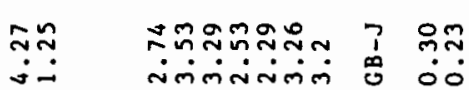

- บำกำกำ

$\sim^{2}$ 00ำ-

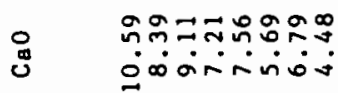

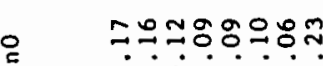

ᄃ 00000000

- ำกำำำ

x anninio:

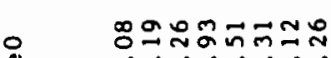

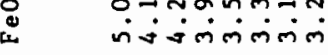

0

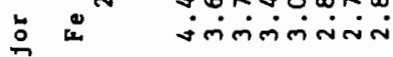

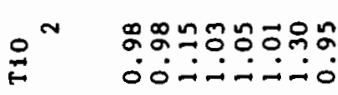

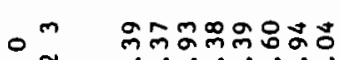

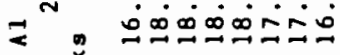

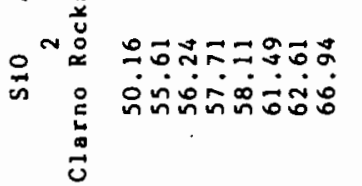

辛

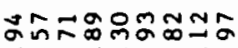

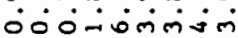

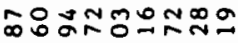

$\infty 0^{\circ} 00000000$

ำำำำำ

○00000010

รักกำกับป

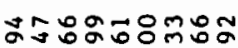

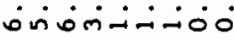

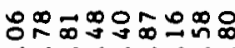

ofinimionio

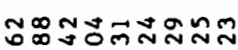

inivio0,0.00

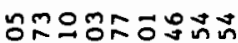

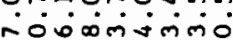

0
$\vdots$
0
0
0
0
0
$\vdots$
$\vdots$
0

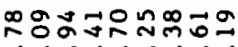

ogioninivio

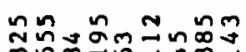

mom $\rightarrow 0=$ ज.

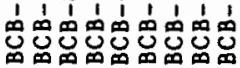

जिinio $00^{\circ} 0^{\circ}$
造

(5)

चี゙

政

ำ

i- $0 \dot{0}-00 \div 0$

요

no

nกำ

ํํํํํำำ

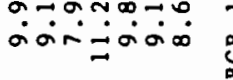

ஸ̊㇒

葛

$\dot{0}$

离

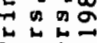

$\forall \vec{N}=\overrightarrow{0}$

O०

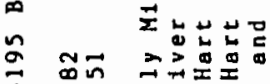

$\therefore \dot{0} \propto \Delta$

w

舟

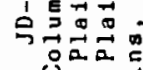

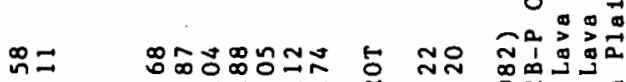

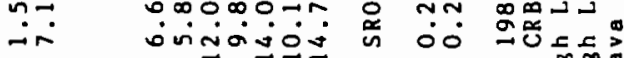

- $\stackrel{\infty}{\rightarrow \infty}$

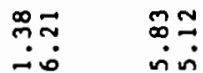

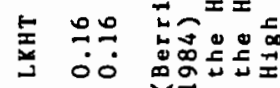

no ñogor

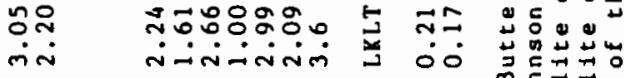

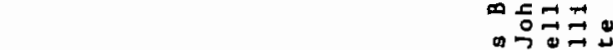

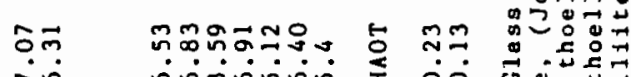

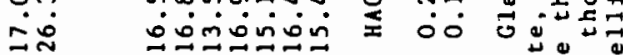

岁苟至

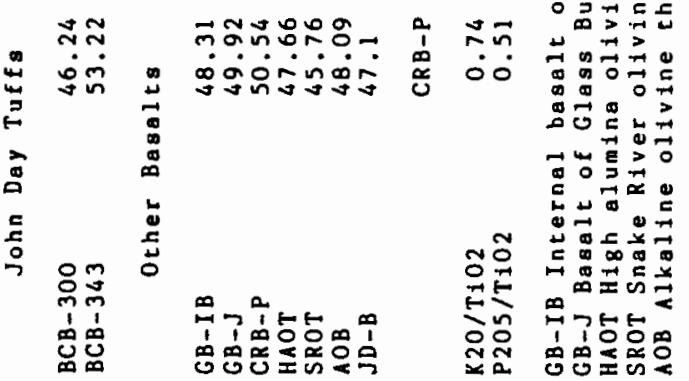




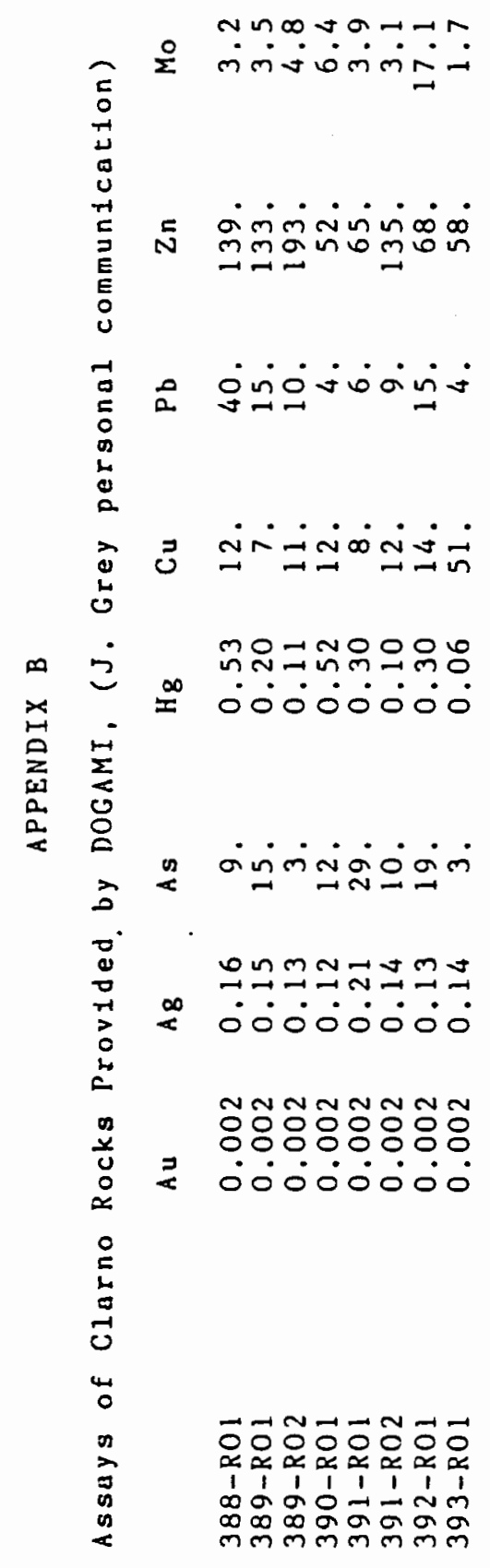




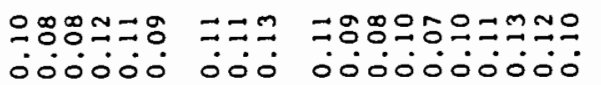

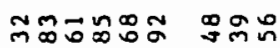
iัンic:

ทำกำำำ ถุํำ 000000

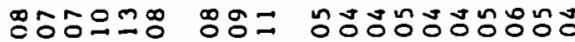
000000 000 0000000000

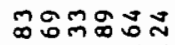
$\dot{\sim}=\infty \dot{\sim} \dot{\sim}$ $\stackrel{\infty}{\Im}=$ inin

옹용ㅇㅇㅇㅛ

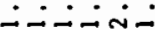
으으붕용으

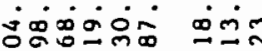

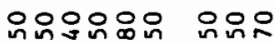
000000 000

응으응ㅇㅇ 욱유유

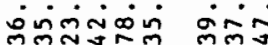

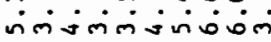

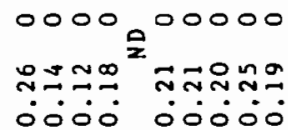

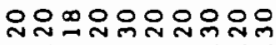
0000000000

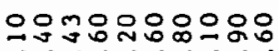

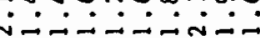

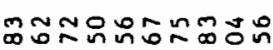
00000000-0

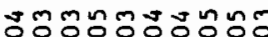
0000000000

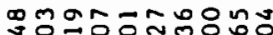
$\therefore \therefore-\therefore-n \dot{0}$

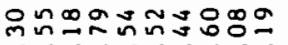

\section{양ㅇㅇㅇ}

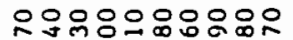

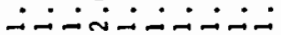

뭉

윰융웅유용

음웅ㅇㅇ으응ㅇㅇㅇㅜ

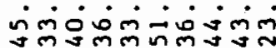

$8 \%$

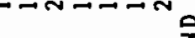

ㄴำ

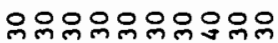
000000000

융ำ $\therefore \circ$

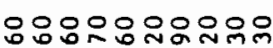
=minimingos

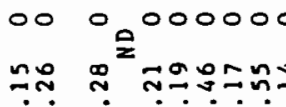
ó 0 00000

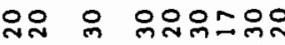
-0 000000 융요 z

z

응으웅

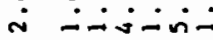

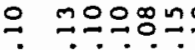
0000000 年

유 n

$\circ 0$ : $00=0$

ำำ $00^{\circ}$

nm is

ำำ .0

nim in

noñ

ำํำํํํํํำ 00000000

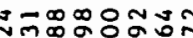
-000ரiono

4.moth

\section{잉요} 은응용ㅇㅇ

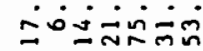

กกดัธล์กัก -ONinginán

- 000000000000 $\pm$

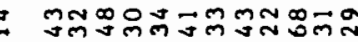
- 00000000000.

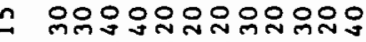
- 000000000000

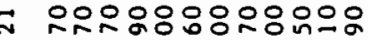
- mininininiminivi-

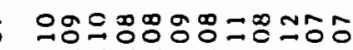
- 000000000000

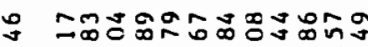
-

ํํㅇ ํํㅇํํㅇํㅇํํㅇํㅇํㅇำ

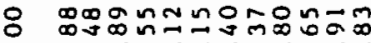
- Zz-2iniono

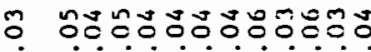
- 000000000000

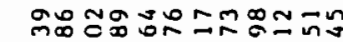
ovososinisions

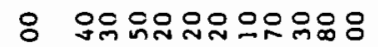

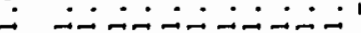
$\infty$

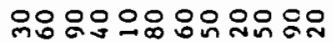
○

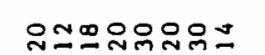
00000000

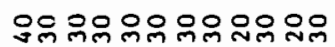
000000000000 우숭ㅇㅇㅇㅇㅇㅇㅇㅇ

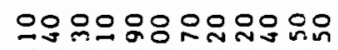
$\therefore$ वतं

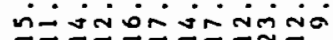

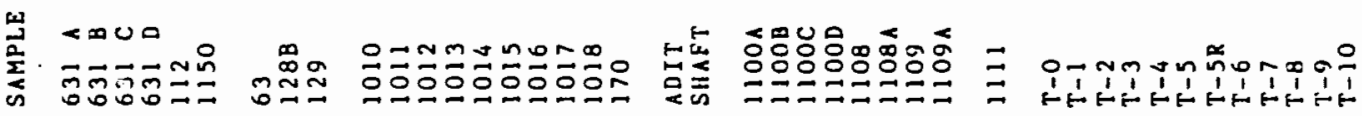


3

思

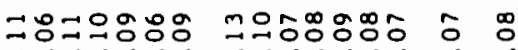
0000000 000000்

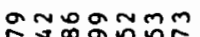
०000000

o.janan

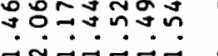

$\stackrel{0}{\circ}$

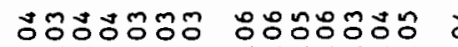

¿

记

0
$x$
0
0
$a$
$a$
$a$
$a$
$a$

is

0000000 0000000

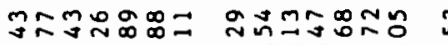

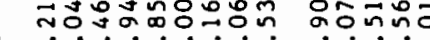

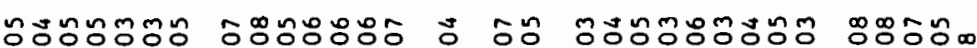
0000000 0000000

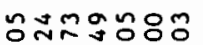

Divinimio

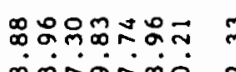

comisirió

嗢

ain

ن0000000

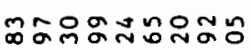

ininivinimin

ㅇํㅇㅇㅡำกำำ

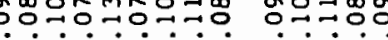

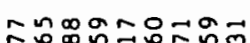

000000000

ถูกละ์

ini-j:-

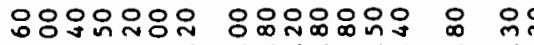

㟧

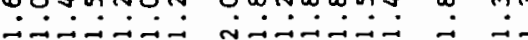

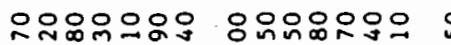

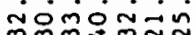

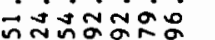

용요

$\because 2$

a

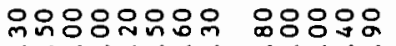

a

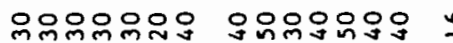

s

0000000 0000000 0́

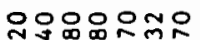

invinom

응유융요용 응 은

ari-iñ
문

깅ㅇㅇㅇㅇㅇㅇㅇㅁㅇㅛ

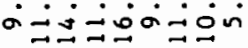

อีดกัดั

0000

몽요요

வ0000

윙융유융

०0000

융유옴

nivinini

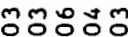

00000

0.000

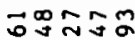

$0 \dot{0}=0$

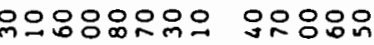

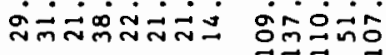

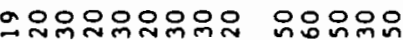

000000000 00000

옹윰윰요

míni

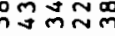

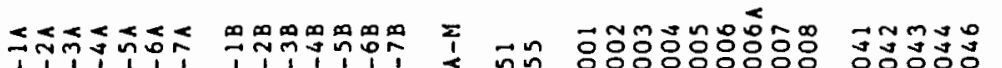

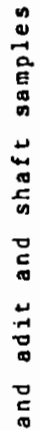

\begin{tabular}{l}
0 \\
0 \\
0 \\
0 \\
0 \\
0 \\
0 \\
0 \\
\hdashline \\
$\vdots$ \\
0
\end{tabular}

$\stackrel{\infty}{\circ}$

i

要蕰

:

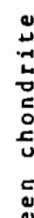

๑

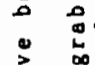

$\stackrel{0}{=}$

号

$\overrightarrow{0}$

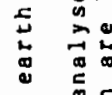

$\stackrel{2}{a}=\frac{5}{5}$ 


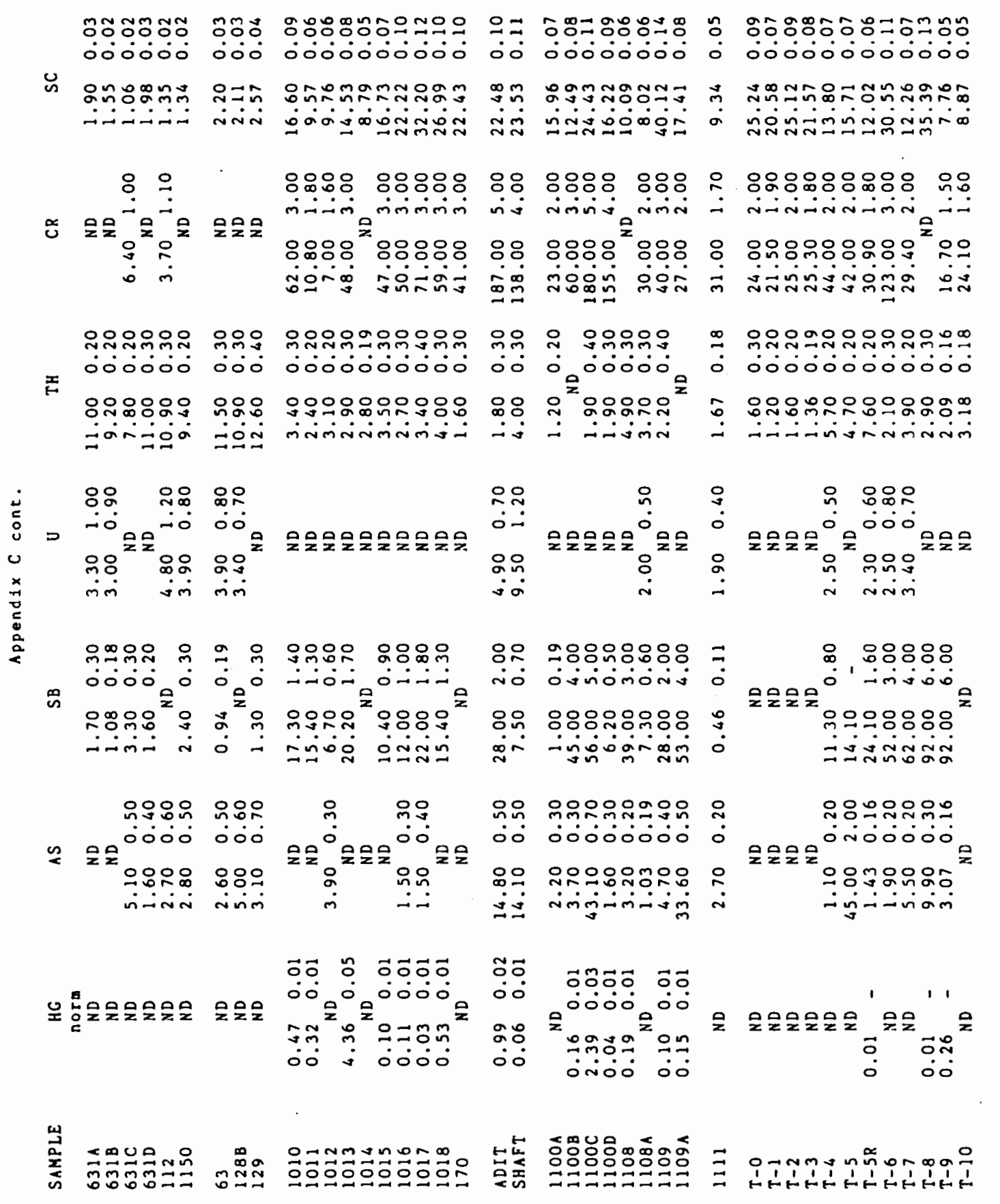


¿

品

I

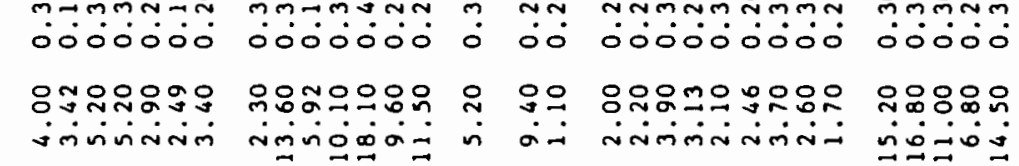

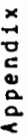

ต

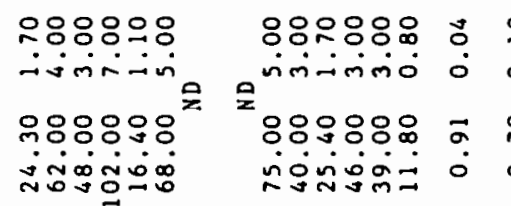

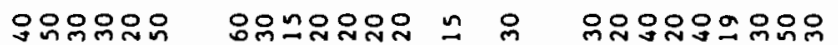

2

000000 d000000

응용요용

نูinis:
옹유용

rivinimio in

융유용ㅇㅇㅇㅇㅛ

i.

웅ㅇㅇ을

25000808

ongriving

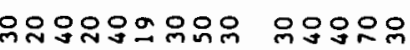
000000000

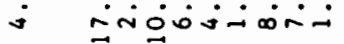

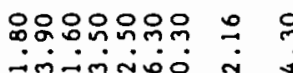

00000

융용요

ن० $0^{\circ} 0^{\circ}$

궁ㅇㅇㅇㅠ

סOंज-

둥용ㅇㅇㅇ

$\therefore$ - invis

임웅요

융요융요

लिंतin

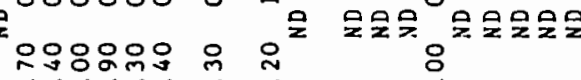

양ㅇㅇ응요유

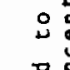

:

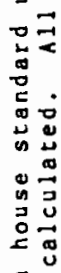

돈

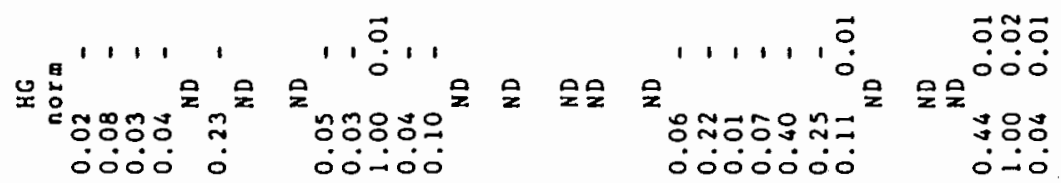

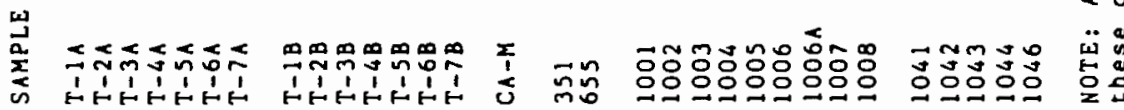


$E$

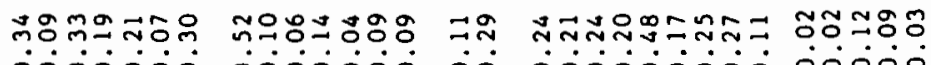
0000000 0000000 00 00000000 00000

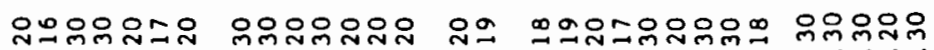
崖 0000000 0000000 00 000000000 00000

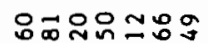
minivininim 윳유억영ㅇㅇㅇ $\therefore \operatorname{ino\infty } 0 \dot{0}$ 8 sin

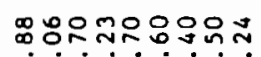
Niñminimin nimiñ

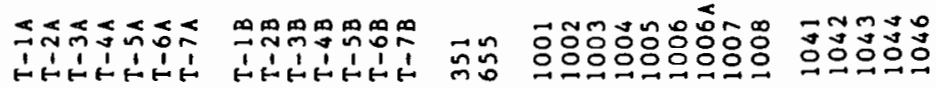

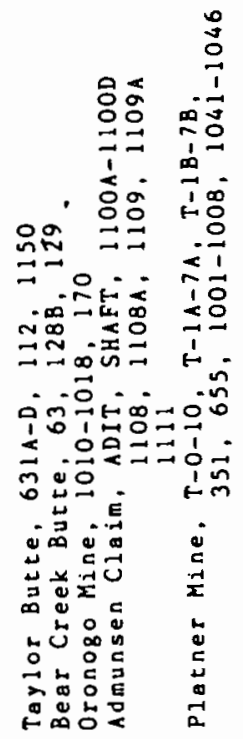

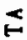

ตำกำ ०00000

\section{Imy}

ำปลีกำกี่ ०0ं 000000000ं

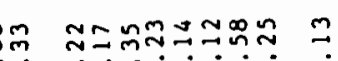
00

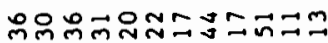
000000000000

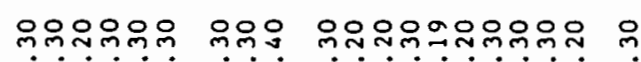
00000 000 000000000

웅용움으 우응 ñangin

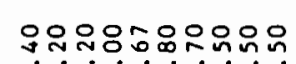
용요 응유윰유 $\rightarrow$

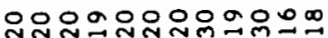
- j00000 000000000000 을ㅇㅇㅇㅇㅇㅇㅇㅇㅛ

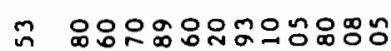

\section{㖣}

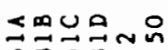

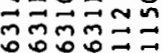

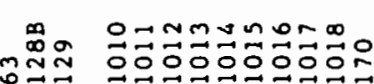

点喪

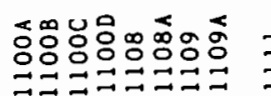

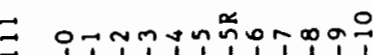

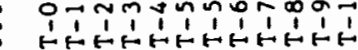




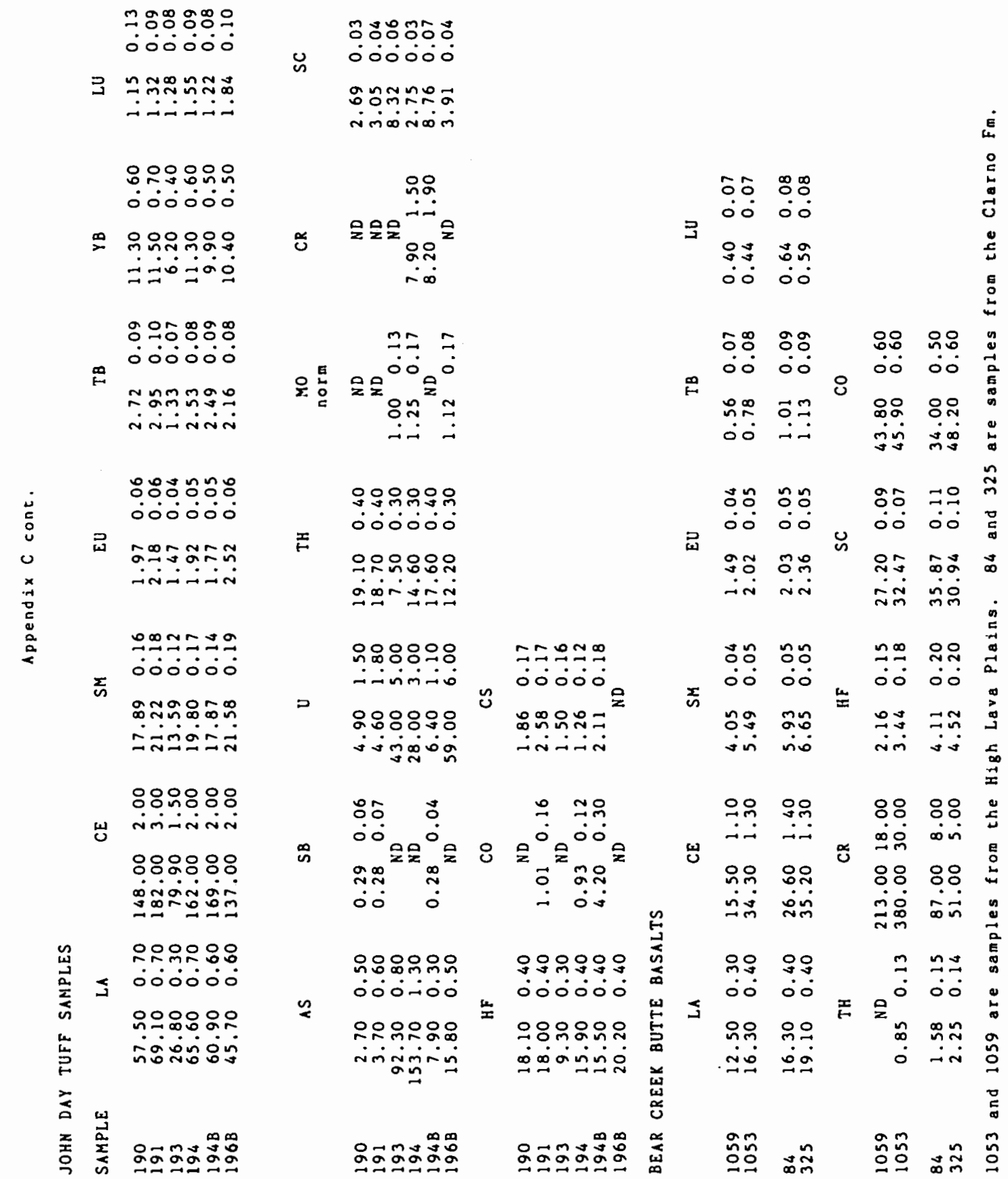


INAA Sample Preparation Of Samples In Apppendix $\underline{C}$

Eighteen to twenty grams of sample are powdered in a mortar and pestle. From this approximately a 1 gram split is obtained for analysis. The sample is placed in a cleaned, weighed, polyethylene vial. The filled vial is reweighed to determine the sample weight. Plastic gloves are used when handing the vials to avoid sodium contamination of the vials.

Instrumental Neutron Activation Analysis

The samples are loaded into a rotatable sample container and irradiated by thermal neutrons in the TRIGA Mark II reactor at Reed College. The samples rotate at 1 rev/min for 1 hour to ensure a uniform neutron flux. After the detector dead time is approximately $10 \%$ the irradiated samples are individually counted in a high resolution Ge-Li detector for gamma ray emission. Two counts are made.

The first count is for 1000 seconds (samples) and $5000 \mathrm{sec}$. (standards); the second count is $3000 \mathrm{sec}$. (sample), and $9999 \mathrm{sec}$. (standards).

The detector system also contains a 4096 channel analyzer. During detection the characteristic energies of specific isotopes appear as statistically defined peaks rising above a continuous background. The abundences of isotopes is statistically calculated by identifying peaks from the background and intergrating the areas under them. This data, as well as standard isotopic concentrations 
and half lives of isotopes, is then fed into the INAA program in the Honeywell computer and processed to give the specific element concentrations and the statistical error boundaries, which are based on one standard deviation. 